

\title{
Implementatieplan genenbank bomen en struiken
}

Joukje Buiteveld, Anjo de Jong, Paul Copini en Lammert Kragt 



\title{
Implementatieplan genenbank bomen en struiken
}

Joukje Buiteveld ${ }^{1}$, Anjo de Jong ${ }^{2}$, Paul Copini ${ }^{1}$ en Lammert Kragt ${ }^{3}$

\author{
1 Centrum voor Genetische Bronnen, Nederland \\ 2 Wageningen Environmental Research \\ 3 Staatsbosbeheer
}

Dit onderzoek is uitgevoerd door CGN en gesubsidieerd door het ministerie van Landbouw, Natuur en Voedselkwaliteit (LNV), in het kader van BO Duurzame voedselvoorziening \& -productieketens (projectnummer BO-43-023.01-040).

Centre for Genetic Resources, the Netherlands (CGN), Wageningen University \& Research Wageningen, februari 2021 
Joukje Buiteveld, Anjo de Jong, Paul Copini \& Lammert Kragt, 2021. Implementatieplan genenbank bomen en struiken. Centre for Genetic Resources, the Netherlands (CGN), Wageningen University \& Research, CGN rapport 53. 52 blz.; 8 fig.; 11 tab.; 12 ref.

In dit rapport wordt een implementatieplan gepresenteerd voor een duurzame instandhouding en ontwikkeling van de genenbank voor inheemse bomen en struiken. Het betreft acties en maatregelen die nodig zijn om de bodem en waterhuishouding van Roggebotzand en de inrichting en het operationeel beheer van de genenbank te verbeteren. Mogelijkheden voor de collectieopbouw qua soorten- en accessiesamenstelling worden geschetst in meerdere scenario's. Daarnaast worden maatregelen ten behoeve van het opslaan van veiligheidsduplicaten in een back-upcollectie beschreven. Voor alle maatregelen en scenario's worden de bijbehorende financiële consequenties besproken en wordt een planning in de tijd aangegeven. Ten slotte worden aanbevelingen gedaan op basis van de voor- en nadelen van de beschreven maatregelen en scenario's.

This report presents an implementation plan for future development of the gene bank for native trees and shrubs. The plan concerns actions and measures to improve soil and water management of the location Roggebotzand and the operational management of the gene bank. Development of the collection concerning species and accessions are outlined in several scenarios. Also, measures for storage of safety-duplicates in a backup collection are described. The costs are discussed for all measures and scenarios and a time schedule is indicated. Finally, recommendations are made based on the pros and cons of the described measures and scenarios.

Dit rapport is gratis te downloaden op http://doi.org/10.18174/542261 of op www.wur.nl/cgn onder CGN rapporten.

(C) 2021 Centre for Genetic Resources, the Netherlands (CGN), Wageningen University \& Research E cgn@wur.nl

Wageningen University \& Research aanvaardt geen aansprakelijkheid voor eventuele schade voortvloeiend uit het gebruik van de resultaten van dit onderzoek of de toepassing van de adviezen.

Alle rechten voorbehouden. Niets uit deze uitgave mag worden vermenigvuldigd en/of openbaar gemaakt worden door middel van druk, fotokopie, microfilm of op welke wijze dan ook zonder voorafgaande toestemming van de uitgever of auteur.



De certificering volgens ISO 9001 onderstreept ons kwaliteitsniveau.

Foto omslag: Genenbank Roggebotzand (L. Kragt) 


\section{Inhoud}

$\begin{array}{ll}\text { Samenvatting } & 5\end{array}$

1

$\begin{array}{ll}\text { Inleiding } & 7\end{array}$

$\begin{array}{lll}1.1 & \text { Achtergrond } & 7\end{array}$

$\begin{array}{lll}1.2 & \text { Opdracht } & 8\end{array}$

$\begin{array}{lll}1.3 & \text { Leeswijzer } & 8\end{array}$

$\begin{array}{ll}\text { Operationeel beheer } & 9\end{array}$

2.1 Locatie Roggebotzand 9

2.1.1 Verbetering bodem 9

2.1.2 Verbetering waterhuishouding 10

2.2 Operationeel beheer $\quad 11$

2.2.1 Bemestingsplan 11

2.2.2 Monitoring bodemvochtigheid 11

2.2.3 Teelt- en verjongingsplan $\quad 12$

2.2.4 Monitoringsplan $\quad 12$

2.2.5 Omvormingsplan randbeplanting 12

2.2.6 Faunabeheer $\quad 12$

2.2.7 Markering en labeling collecties $\quad 13$

$\begin{array}{lll}2.3 & \text { Inrichting terrein } & 13\end{array}$

2.3.1 Exclavering genenbank Roggebotzand 13

2.3.2 Voorlichting en recreatie 13

2.4 Fasering 14

$\begin{array}{lll}2.5 & \text { Kosten en investeringen } & 15\end{array}$

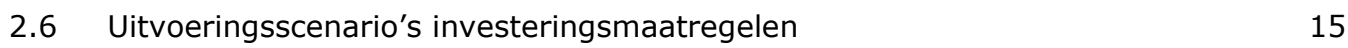

$3 \quad$ Soortensamenstelling en opbouw collecties $\quad 17$

3.1 Opbouw en prioritering van collectie en soortensamenstelling 17

3.2 Scenario's genenbankcollectie 'Minimaal' versus 'Optimaal' 17

3.3 Optimalisatie en uitbreiding van de collectie in scenario $2 \quad 19$

3.3.1 Optimalisatie accessiesamenstelling 19

3.3.2 Uitbreiding prioritaire soorten $\quad 22$

$\begin{array}{lll}3.4 & \text { Fasering } & 22\end{array}$

3.5 Berekening kosten voor collectie beheer 23

$\begin{array}{lll}3.6 & \text { Kosten per scenario } & 26\end{array}$

3.6.1 Kosten scenario 1 Minimaal $\quad 27$

3.6.2 Kosten scenario 2 Optimaal $\quad 27$

3.6.3 Optimalisatie van het aantal planten per accessie $\quad 27$

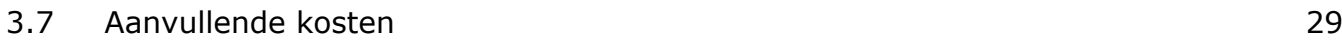

4 Opbouw van back-upcollecties $\quad 30$

4.1 Achtergrond 30

$\begin{array}{lll}4.2 & \text { Methoden } & 30\end{array}$

4.3 Zaadopslag-gedrag en kiemrust-karakteristieken $\quad 32$

4.4 Stappen in het opbouwen van back-upcollecties 33

4.5 Kennisontwikkeling $\quad 34$

4.6 Samenwerking $\quad 34$

$\begin{array}{lll}4.7 & \text { Fasering } & 35\end{array}$

4.8 Benodigde faciliteiten voor back-upcollecties $\quad 35$

4.9 Kostenraming voor back-upcollecties $\quad 36$ 
5.1 Inrichting en operationeel beheer van Roggebotzand 37

5.2 Opbouw collecties $\quad 38$

$\begin{array}{lll}5.3 & \text { Back-upcollecties } & 41\end{array}$

Literatuur $\quad 42$

Bijlage 1 Kaarten sloten Roggebotzand 43

Bijlage 2 Uitbreiding accessies in genenbank per soort 46

Bijlage 3 Maatregelen voor aanleg en onderhoud $\quad 47$

Bijlage 4 Fasering aanleg zaadcollecties $\quad 50$ 


\section{Samenvatting}

Het veiligstellen van genetische bronnen van bomen en struiken is een publieke taak. Deze publieke taak heeft het ministerie van LNV belegd bij Staatsbosbeheer (SBB) en het Centrum voor Genetische Bronnen Nederland (CGN) van Wageningen University \& Research. Het CGN ondersteunt en adviseert SBB bij de opbouw, instandhouding en documentatie van de genenbankcollecties in het Roggebotzand vanuit het WOT-programma Genetische Bronnen. SBB is verantwoordelijk voor het beheer en het onderhoud.

In 2019 heeft CGN in samenwerking met SBB de huidige genenbank en collectiesamenstelling geëvalueerd en een onderbouwd advies uitgebracht over de gewenste kwaliteit en omvang van relevante soorten in de genenbank. LNV heeft CGN en SBB verzocht de belangrijkste aanbevelingen die zijn gedaan in deze evaluatie uit te werken in een implementatieplan.

In dit rapport wordt het implementatieplan gepresenteerd. Het betreft acties en maatregelen die nodig zijn om de bodem en waterhuishouding van Roggebotzand en de inrichting en het operationele beheer van de genenbank te verbeteren, de opbouw en prioritering van de collectie en soortensamenstelling te optimaliseren en het gaat om maatregelen ten behoeve van het opslaan van veiligheidsduplicaten in een back-upcollectie. Voor alle maatregelen worden de bijbehorende financiële consequenties besproken en wordt een planning in de tijd aangegeven.

De verbeter- en herstelmaatregelen hebben betrekking op de bodem, waterhuishouding, faunabeheer, recreatie en registratie en monitoring van de collectie. Aanbevolen wordt deze eenmalige investeringen te realiseren, waardoor de locatie Roggebotzand geschikt gemaakt kan worden voor een groot deel van de collectie. Het belangrijkste argument om Roggebotzand aan te houden, is dat het verplaatsen van een collectie of opnieuw opzetten onder kwekerijomstandigheden als financieel en praktisch onhaalbaar wordt gezien.

De toekomstige ontwikkeling van de genenbank qua opbouw van de collecties (soorten en accessies) is uitgewerkt aan de hand van twee scenario's: een minimale ontwikkeling, waarin de huidige collecties slechts worden gehandhaafd en een scenario waarin de huidige collectie geoptimaliseerd wordt door nieuwe accessies en soorten aan de collectie toe te voegen. De beheerkosten zijn voor beide scenario's doorgerekend. In deze scenario's is een onderscheid gemaakt tussen soorten waarvoor bescherming via de genenbank essentieel is (prioritaire soorten) en soorten die zijn opgenomen in de genenbank met als doel op een kostenefficiënte manier zaad te oogsten (complementaire soorten). Geadviseerd wordt de genenbank verder te ontwikkelen voor de prioritaire soorten conform het optimale scenario over een periode van 5-10 jaar, met uitzondering van soorten waarvoor een veldcollectie op Roggebotzand wordt afgeraden. Voor deze soorten is het aanleggen van zaadcollecties als conserveringsmethode het kostenefficiëntst.

Daarnaast worden maatregelen ten behoeve van het opslaan van veiligheidsduplicaten in een backupcollectie beschreven. Geadviseerd wordt te kiezen voor de aanleg van back-upcollecties in de vorm van een zaadbank. Bij voorkeur wordt gestart met soorten die het risicovolst en kwetsbaarst zijn en die niet opgenomen kunnen worden in de veldcollectie van Roggebotzand in verband met ziekte en ongeschiktheid van de groeiplaats. Het betreft de soorten waarvoor onder het optimale scenario een alternatief gezocht wordt. 


\section{$1 \quad$ Inleiding}

\subsection{Achtergrond}

Sinds 2002 heeft Nederland een genenbank voor inheemse bomen en struiken. Met deze genenbank wordt autochtoon genetisch materiaal veiliggesteld voor de lange termijn en wordt een bijdrage geleverd om het wereldwijde verlies aan biodiversiteit tegen te gaan. Uit de genenbank wordt tevens stek en zaad beschikbaar gesteld aan gebruikers, voornamelijk door de collecties als zaadbron op de rassenlijst bomen te plaatsen. Op deze wijze draagt de genenbank ook op korte termijn bij aan het optimaal gebruik van genetische diversiteit in de Nederlandse bossen.

Nederland heeft zich in een aantal internationale verdragen en afspraken verplicht inspanningen te leveren op het gebied van conservering en duurzaam gebruik van genetische bronnen van bomen en struiken (CBD, FAO CGRFA, Forest Europe). Het Verdrag inzake Biologische Diversiteit (CBD) is het belangrijkste internationale kader voor het behoud en beheer van genetische bronnen. In de CBD wordt aangegeven dat in-situbehoud de voorkeursstrategie is, maar dat een ex-situstrategie nodig is voor langetermijnbehoud, vooral als aanvulling op in-situbescherming. De uitgangspunten voor de nationale invulling van het Biodiversiteitsverdrag (CBD) zijn verwoord in de Nota Bronnen van ons bestaan (LNV, 2002). Een belangrijke afspraak gemaakt op Europees niveau is de Strasbourg Resolutie (S2) binnen Forest Europe over het plannen en coördineren van in-situ- en ex-situbescherming van genetische bronnen van bomen. Tevens van toepassing zijn de door Nederland geaccordeerde afspraken vastgelegd in de FAO Global Plan of Action for the conservation of forest genetic resources.

Het veiligstellen van genetische bronnen van bomen en struiken is een publieke taak. Deze publieke taak heeft het ministerie van LNV belegd bij het Staatsbosbeheer (SBB) en het Centrum voor Genetische Bronnen Nederland (CGN) van Wageningen University \& Research. Het CGN ondersteunt en adviseert SBB bij de opbouw, instandhouding en documentatie van de genenbankcollecties in het Roggebotzand vanuit het WOT-programma Genetische Bronnen. SBB is verantwoordelijk voor het operationele beheer en het onderhoud.

Vanuit deze beleidsverantwoordelijkheid heeft LNV behoefte om na te gaan of in de huidige opzet aan de ambities voor instandhouding en stapsgewijze groei van de genenbank kan worden voldaan. Om deze reden heeft het CGN in 2019 in samenwerking met SBB het huidige beheer van de genenbank en de collectiesamenstelling geëvalueerd en een onderbouwd advies uitgebracht over de kwaliteit en omvang van relevante soorten in de genenbank (Buiteveld and Copini, 2019). De belangrijkste aanbevelingen uit dit advies liggen op het volgende vlak:

- Verbetering van de groeiplaats en operationeel beheer van de genenbank. Roggebotzand is een onderhoudsintensieve locatie voor een genenbank, waardoor onnodige kosten worden gemaakt die voorkomen kunnen worden door andere locaties te gebruiken. Wanneer Roggebotzand als locatie aangehouden wordt, zullen er naast de reguliere beheerkosten investeringen moeten worden gedaan om deze locatie structureel te verbeteren. Alternatieven zijn de gehele collectie of delen ervan (bijv. soorten die een rijkere bodem vragen) te verplaatsen naar andere locaties. Aanbevolen wordt de mogelijkheden tegen elkaar af te wegen en in detail uit te werken.

- Opbouw en prioritering van de collectie en soortensamenstelling. Het advies is om 52 soorten van de 98 beschouwde inheemse boom- en struiksoorten, op te nemen in de genenbank. Van de 52 soorten staan er momenteel 35 in de genenbank, waarvan 19 zeer sterk bedreigd. Op korte termijn (komende vijf jaar) is het wenselijk niet te sterk te prioriteren wat betreft het aantal soorten, maar zo veel mogelijk prioritaire soorten op te nemen in de genenbankcollectie en desnoods minder materiaal per soort. Het belangrijkste argument hiervoor is dat voor de meeste soorten momenteel geen alternatieve conserveringsstrategieën aanwezig zijn. Geadviseerd wordt de samenstelling van de collectie te optimaliseren.

- Voor de middellange termijn wordt aangeraden de gehele collectie te dupliceren, met nadruk op het inzetten van nieuwe ex-situmethoden (zaadbank, cryopreservatie). Onderzocht kan worden hoe dit 
het kostenefficiëntst gerealiseerd kan worden (per soort) en welke investering in kennisontwikkeling nodig is om deze technieken op termijn toepasbaar te maken bij bomen en struiken.

\subsection{Opdracht}

Begin 2020 heeft LNV de opdracht geformuleerd aan CGN en SBB om bovenstaande aanbevelingen uit het rapport nader uit te werken. De opdracht moet resulteren in een implementatieplan waarin prioritering, fasering in de tijd en budgetimplicaties van de te nemen maatregelen worden aangegeven. In het implementatieplan komen de volgende elementen aan de orde:

- Het uitwerken van urgente acties en maatregelen t.a.v. het operationele beheer en het verbeteren van de locatie Roggebotzand.

- Het uitwerken van de opbouw van de collectie en soortensamenstelling in twee scenario's (huidige collectiesamenstelling vs. optimale samenstelling) en fasering in de tijd. Hierbij wordt een onderscheid gemaakt tussen soorten waarvoor bescherming via de genenbank essentieel is (prioritaire soorten) en soorten die ook zijn opgenomen met als doel op een kostenefficiënte manier zaad te oogsten (complementaire soorten).

- Het uitwerken van maatregelen t.a.v. dupliceren, inclusief een verkenning van mogelijkheden, faciliteiten en kennisontwikkeling om nieuwe technieken mogelijk te maken.

\subsection{Leeswijzer}

CGN en Staatsbosbeheer hebben gezamenlijk de maatregelen, urgente acties en scenario's uitgewerkt in dit implementatieplan. De drie elementen van het implementatieplan worden in hoofdstuk 2, 3 en 4 uitgewerkt. Het rapport wordt in hoofdstuk 5 afgesloten met samenvattende aanbevelingen en conclusies.

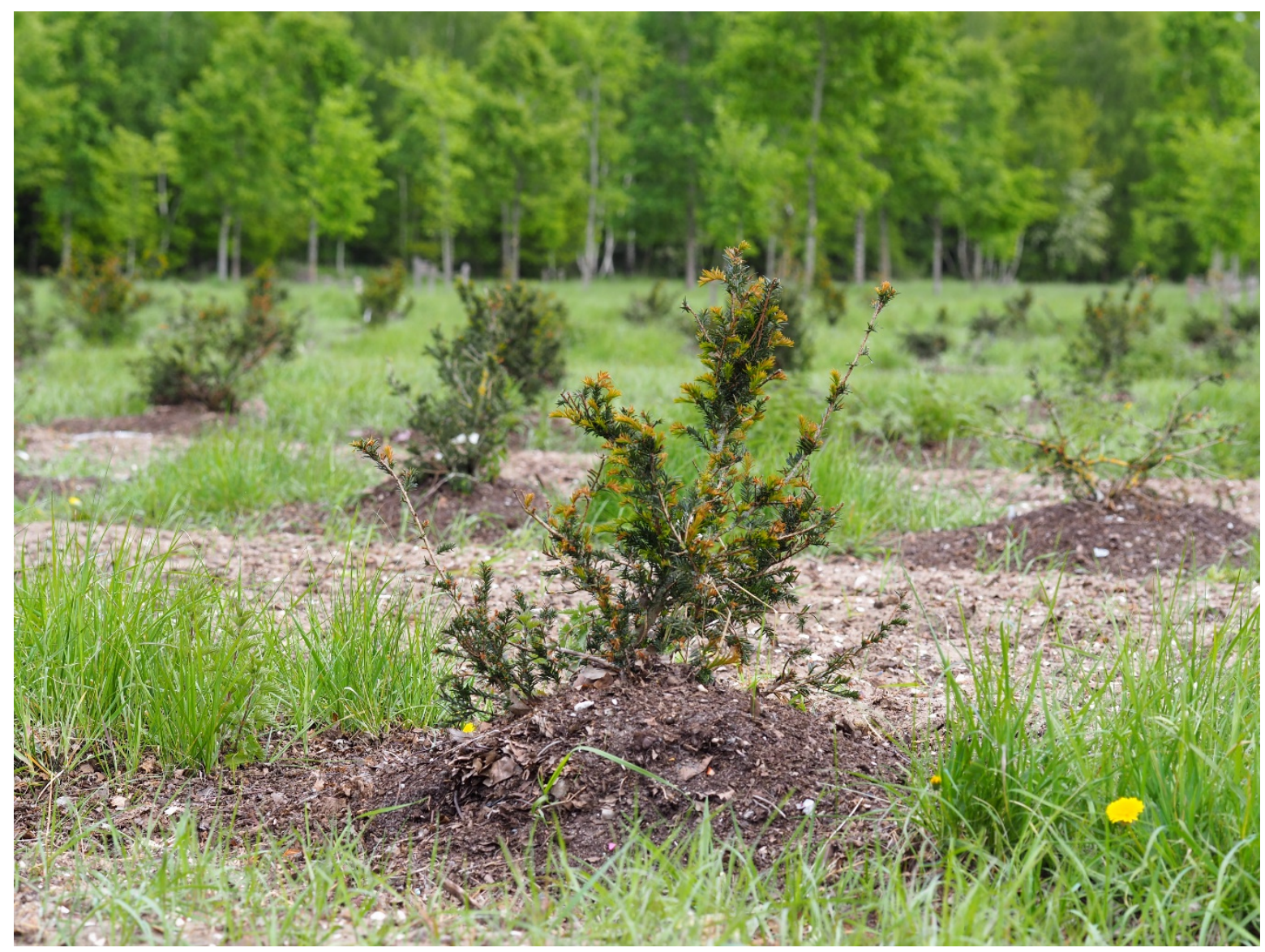

Figuur 1.1 Recentelijk aangelegde collectie van Taxus baccata in de genenbank. 


\section{Operationeel beheer}

In dit hoofdstuk worden aanbevelingen en maatregelen uitgewerkt aangaande verbetering van de groeiplaats, de inrichting van het terrein en het operationele beheer van de genenbank in Roggebotzand.

\subsection{Locatie Roggebotzand}

De locatie Roggebotzand is in beginsel geschikt voor een groot deel van de bomen en struiken die in de collectie zijn opgenomen. In Bijlage 2 van het evaluatierapport (Buiteveld en Copini, 2019) is de vitaliteit van de bestaande collectie aangegeven en daarmee de knelpunten per soort. Van de 57 soorten staan de collecties van 16 soorten onder druk (matige vitaliteit) en staan 11 soorten er slecht voor. De slechte vitaliteit bij veel bomen en struiken uit zich in een verstoorde groei als gevolg van een slechte wortelvorming en slechte bladontwikkeling. In droge jaren is ook de vruchtzetting en zaadontwikkeling matig tot slecht. Niet alle soorten staan nog op Roggebotzand. De Myrica gale- en Daphe mezereum-collecties zijn opgeheven. In 2018-2019 is gestart met een tweede locatie van de genenbank op rijkere bodem in het gebied Hollandse Hout-Zuid en Lelystad-Noord (Flevoland) met soorten als Carpinus betulus, Malus sylvestris, Rosa spp. en Ulmus laevis.

\subsubsection{Verbetering bodem}

Een belangrijk knelpunt van Roggebotzand is de bodemgesteldheid. De bodem bestaat grotendeels uit fijnzandig Ramspolzand met een zeer hoge kalktoestand (schelpkalk-gefixeerd), met pleksgewijze storende lagen uit de pre-Zuiderzeefase en is slempgevoelig. Naar het westen toe wordt het profiel geleidelijk aan zaveliger van aard, maar dat heeft binnen de begrenzing van de genenbank nauwelijks effect. Het organischestofgehalte is zeer laag en de mineralenhuishouding is verstoord als gevolg van de grootschalige noodvellingen van fijnspar die eerder in het gebied stonden. Er ligt nog een overmaat aan onverteerd houtafval als gevolg van de vellingen onder dan wel in het profiel en deels op het maaiveld, dat in de eerste plaats verstorend werkt op de mineralenhuishouding (overmaat aan kalium). Vanaf het begin is het profiel gewoeld met een zware bodemwoeler om daarmee storende lagen te doorbreken en de lucht- en waterhuishouding in het profiel te verbeteren. Daarnaast is de afgelopen jaren gewerkt aan het vitaliseren van het bodemprofiel door het inbrengen van organisch materiaal (blad) ter verbetering van het organischestofgehalte en het bemesten met mineralen, waaronder Magnesite (Mg), Zeewierkalk (Ca oplosbaar en sporenelementen) en Sea 90 (sporenelementen). Sinds 2020 is ook bemest met DCM bloedmeel (N), DCM fosfor (P); deze laatste vooral op rozen.

Maatregelen die nodig zijn om de bodem te verbeteren, zijn:

$>$ De komende jaren het organischestofgehalte op peil brengen door een gift van ten minste 15 ton per hectare per jaar (norm ruige stalmest).

$>$ Het in kaart brengen van de profielopbouw en zo een overzicht krijgen van de groeiplaatsomstandigheden. Hiervoor kan de bodemkartering van de RIJP (dr. P.J. Ente) nog gebruikt worden en vertaald worden naar de huidige normen van de bodemkundige nomenclatuur op basis van de bodem(subgroepen)kaart, schaal $1: 10.000$.

$>$ Een bodemkundig onderzoek naar het organischestofgehalte en de mineralenhuishouding.

$>$ Het opstellen van een bemestingsplan (voor korte en lange termijn).

$>$ Een advies voor mechanisch onderhoud - hoe lang en waar moet het bodem woelen worden volgehouden?

$>$ Bovenstaande karteringen/plannen moeten vlakdekkend worden geïnventariseerd en opgesteld voor zowel genenbank oost als west. In totaal gaat het om een gebied van ongeveer 48 hectare. 


\subsubsection{Verbetering waterhuishouding}

De waterhuishouding is ernstig verstoord en daarmee ook het waterbergend en/of waterdrainerend vermogen van het bodemprofiel. Dat geld voor beide compartimenten van de genenbank (oost en west). De verstoring wordt teweeggebracht door de 'natuurlijke ontwikkeling' van de polderbodem in zijn geheel alsook door verstoring als gevolg van slecht onderhoud van de artificiële waterbeheervoorzieningen in de gehele omringende boswachterij. Het oostelijke deel van de genenbank is gekoppeld aan het waterbeheer van de boswachterij en de daaraan gekoppelde peilvakken in de Roggebottocht. De dijkse kwelsloot voert water aan vanaf de Vossemeerdijk door de hoofd(schouw)sloten naar de Roggebottocht. In de Roggebottocht zitten vier peilvakken waarlangs het overschot aan water wordt afgevoerd in noordelijke richting naar de Hoge vaart en via de uitwateringssluis bij gemaal Colijn in het Vossemeer-Ketelmeer geloosd wordt. Ten gevolge van de permanente bodemdaling trekken de diepere kwelstromen steeds verder in westelijke richting. Dat is vooral te merken in het westelijke compartiment van de genenbank. In natte periodes staat het water voortdurend op het maaiveld (gevoed door het diepere kwelwater en door hemelwater dat via het verzadigde profiel niet kan worden afgevoerd). Het bos Roggebotzand is in de jaren zestig van de vorige eeuw niet voor niets grotendeels op rabatten geplant en zijn grote delen beplant met fijnspar en later ook populieren. De oorspronkelijke afstand van de greppels en drainagereeksen bedroeg 8 tot 12 meter. Het water van het westelijke compartiment wordt via de hoofd(schouw)sloten afgevoerd naar de Keteltocht die, evenals de Roggebottocht, het water loost op de boezem Ketelmeer-Vossemeer. Het water in de Roggebottocht is van goede kwaliteit, het water in de Keteltocht is daarentegen van slechte kwaliteit (te zout en ijzerrijk).

Bovenstaande leidt tot de volgende problemen in het gebied:

$>$ Bodemdaling, diepere kwelstromen werken vooral vernattend op het westelijke deel gedurende het winterseizoen en ijlen na in het vroege voorjaar, waardoor sterfte van wortels optreedt als gevolg van zuurstofgebrek.

> De hoofdwatergangen (schouwsloten) zijn ernstig verwaarloosd, waarbij het doorstroombare profiel is verzakt, vermodderd en dichtgegroeid met houtopslag. De kunstwerken zijn verzakt (dammen en duikers). Er zijn geen mogelijkheden om het water versneld af te laten of te bufferen. Kortom, in de winter en met name het vroege voorjaar (start wortelactiviteit) is de bodem te nat en zuurstofarm (verzadigd met water pF 2.0). In de zomer is de bodem te droog omdat de kwelstroom zich terugtrekt en/of dieper weg buigt, waardoor het doorwortelbare profiel niet meer in staat is water te bergen of capillair te voeden en al snel het verwelkingspunt wordt bereikt ( $\mathrm{pF} 4.2$ ). Dat wordt nog eens versterkt door het feit dat de profielen op zowel west als oost een zeer laag organischestofgehalte hebben dat mede een snel uitdrogen van het profiel bevordert.

> Plaatselijk hebben ook storende lagen nog een eigen dynamiek in het geheel en versterken of het teveel aan vocht of het tekort.

Voor het oostelijke deel gelden in hoofdzaak min of meer dezelfde problemen, zij het dat het met name in het winterseizoen en vroege voorjaar minder nat is, maar het daarentegen in het late voorjaar en de zomer bij neerslagarme periodes veel te droog wordt. Daar komt bij dat in dit deel de grasvegetatie zeer sterk ontwikkeld is en iedere druppel vocht - inclusief mineralen - voor de boomen struikwortels wegneemt.

Ter verbetering van de waterhuishouding in het gehele gebied en de genenbank Roggebotzand is een aantal maatregelen nodig. Deze maatregelen zijn gebaseerd op een herstelplan opgesteld door Hogeschool Larenstein in 2017-2018 (Wegerif et al., 2019). In hoofdlijnen gaat het om de volgende maatregelen:

> Herstel van doorstroombaar profiel kwelsloot Vossemeerdijk.

> Herstel van de hoofdwatergangen - schouwsloten in het bos en de genenbank wat betreft profilering, afschot, doorstroombaarheid en herstel van de kunstwerken (duikers) (zie Bijlage 1 details schouwsloten).

$>$ Het plaatsen van een hevel ${ }^{1}$ Vossemeer-Vossemeerdijk ter hoogte van N81, een kwelsloot om in droge periode de genenbank te 'voeden' en water efficiënt en snel te kunnen bufferen en daarmee

1 Hevel: voor het plaatsen van een hevel moet een (zware) vergunningsprocedure bij het Waterschap Zuiderzeeland doorlopen worden. Het betreft het inlaten van 'gebiedsvreemd' water. 
te kunnen irrigeren. Het voordeel van een hevel is dat er (veel) minder aanspraak hoeft te worden gemaakt op de watervoorraad en het peilbeheer in de Roggebottocht waar natuurbeleving en biodiversiteit in het stroomgebied van de tocht een belangrijke functie hebben. In droge zomers wordt er nu water vanuit de onderste peilvakken opgepompt en gebufferd in de hogere peilvakken t.b.v. van de genenbank. Een en ander in overeenstemming met het Waterschap Zuiderzeeland. De irrigatie wordt vanuit de tocht via de sloten, slenken en pompen naar de bomen en struiken in de genenbank geleid. Het gaat hier om vele honderdduizenden kubieke meters water. De kosten voor de huidige manier van water geven in droge periodes heeft in de afgelopen droge en hete zomers een extra kostenpost van ten minste $€ 30.000$ per jaar opgeleverd.

$>$ Het plaatsen van extra kunstwerken in de hoofd- en nevensloten (stuwen, slootschotten) om water te bufferen dan wel af te laten.

$>$ Het verbinden van het slotenstelsel tussen de compartimenten oost en west ${ }^{2}$ om daarmee in droge periodes hoogwaardig water vanuit de Roggebottocht in het westelijke compartiment in te laten (irrigatie).

> In het oostelijke compartiment zijn indertijd slenken aangelegd tussen de beplantingsvakken om deze in tijden van droogte vol water te kunnen zetten (oppompen vanuit de Roggebottocht). Deze slenken vertonen echter een onbedoeld neveneffect, namelijk dat in de flauwe taluds van de slenken in periodes van afwatering een opbolling van het freatisch grondwatervlak plaatsvindt (vrij langdurig). Daardoor krijgen/hebben de buitenste rijen bomen en struiken in de taluds van deze slenken een nog slechtere conditie dan de rest t.g.v. zuurstofgebrek voor de wortels. Vervolgens vindt afsterving plaats. De vraag is dan ook of deze slenken bij herstel en een andere mogelijkheid om te irrigeren (via de drains ${ }^{3}$ of via beregening/bevloeiing/druppelinstallatie) gehandhaafd moeten worden.

\subsection{Operationeel beheer}

Het is noodzakelijk dat er een systematisch ingericht beheer- en onderhoudsplan komt. Dit beheerplan geeft inzicht in welke maatregelen eenmalig of periodiek genomen moeten worden. Hieronder worden de maatregelen besproken die in het beheerplan opgenomen moeten worden.

\subsubsection{Bemestingsplan}

Een plan voor jaarlijkse en middellange termijn bemesting, waarbij het uiteindelijke doel is dat de bomen en struiken zich na verloop van tijd zelf (grotendeels) kunnen redden (organischestofgehalte op peil, mineralenhuishouding in balans) door circulaire bedrijfsvoering.

\subsubsection{Monitoring bodemvochtigheid}

Parameters voor beregening/irrigatie dan wel drainage gekoppeld aan een controlesysteem (vochtmeters bodemvochtigheidstoestand), voorzien van peilschalen en kunstwerken. Dit betreft ook het herstel en inrichting van de volgende zaken:

- Stuwen slootpeil genenbank Oost en West (stuwen en aflaten van water);

- Verbinden peilvakken Oost en West via sloten/duikers Roggebottocht - genenbank West om goed (kwaliteit) water in droge perioden in te kunnen laten;

- Herstel dijksloot/kwelsloot als aanvoer-ader voor droge perioden;

- Herstel profielen en kunstwerken bossloten die met de genenbank in verbinding staan;

- Plaatsen van een hevel ter hoogte van kavel N81 Vossemeer-Vossemeerdijk-Boswachterij Roggebotzand voor het inlaten van (gebiedsvreemd) water bij calamiteiten.

\footnotetext{
2 Voor het verbinden van de hoofd-afwateringssloten tussen oost en west moet de Roggebotweg gekruist worden en zullen duikers moeten worden aangelegd. De weg is eigendom van Staatsbosbeheer. Het waterschap zal toestemming moeten geven voor het verbinden van beide peilvakken.

3 De drains liggen op basis van schatting ongeveer op -1.20 meter beneden maaiveld voor zover deze nog intact zijn (wortel-ingroei, verzakking).
} 
Onderzocht kan worden of een digitaal watercontrolesysteem (netwerk aan digitaal uitleesbare vochtmeters in het bodemprofiel) ook gekoppeld kan worden aan het systeem waarmee de posities van de bomen en collecties worden vastgelegd (zie 2.2.7).

\subsubsection{Teelt- en verjongingsplan}

De bomen en struiken in de genenbank hebben een bepaalde omlooptijd. Zaadproductie vraagt veel energie en het mechanisch schudden van met name bomen doet deze snel verouderen en minder vitaal worden. Om de bomen en struiken in fysiek goede conditie te houden, is een periodiek herstel- of snoeiprogramma nodig. Het snoeiprogramma moet erin voorzien dat de betreffende soorten ten minste één keer per vijf jaar 'groot onderhoud' krijgen. Voor sommige soorten, zoals Ribes spp. en Rosa spp., kan het nodig zijn deze jaarlijks te snoeien voor de ontwikkeling van bloei en bessen. Er is een langetermijnplan nodig waarin teelt en periodieke snoei, maar ook vervanging van afgedragen bomen en struiken, zijn opgenomen. Tevens moet daarbij gekeken worden naar alternatieve vormen die minder arbeidsintensief zijn (bijvoorbeeld zoete kers geleiden langs draadconstructies op werkhoogte).

\subsubsection{Monitoringsplan}

De genenbank tendeert sterk naar een boomkwekerij waar je alert moet zijn op ziekten en plagen. Actuele gevaren zijn: bacterievuur (meidoorn), bacterial wetwood (iepen), bacteriekanker (populier), spinselmot (meidoorn, kardinaalsmuts, Prunus), schurft (Ribes), Discula (Cornus), iepziekte (iep). Monitoring van ziekten en plagen moet een vast onderdeel worden van het beheerplan (jaarschijf SBB) om adequate gewasbeschermingsmaatregelen uit te kunnen voeren en zo collecties in conditie te houden en te voorkomen dat materiaal verloren gaat. Tevens moet er zo veel als mogelijk gebruikgemaakt worden van biologische bestrijding van schadelijke organismen om daarmee het gebruik van chemische gewasbeschermingsmiddelen zo beperkt mogelijk te houden. Daarnaast is het merendeel van de collecties uitgangsmateriaal voor de productie van teeltmateriaal, waar onder sommige soorten (Salix, Populus) 'plantenpaspoortplichtig' zijn (zie plantgezondheidsverordening). Implementatie van fytosanitair beheer is nodig, inclusief een monitoringsplan, risicomanagementplan (waaronder Q-organismen) en afspraken met laboratoria/onderzoeksinstituten voor analyse en onderzoek. Voor monitoring kan gedacht worden aan een jaarlijkse controle door Naktuinbouw. Een risicomanagementplan wordt bij voorkeur opgesteld in samenspraak met de Nederlandse Voedsel- en Warenautoriteit (NVWA).

\subsubsection{Omvormingsplan randbeplanting}

In de randbeplanting om de genenbank bevinden zich dezelfde soorten als in de collecties. Veel van dit materiaal is oorspronkelijk van Zuid-Europese oorsprong. Er is kans op inkruisen met ongewenst materiaal (aangezien de meeste boom- en struiksoorten kruisbestuivers zijn) en op inzaai vanuit de bosranden (dit laatste speelt in de wilgencollectie). Dit heeft niet direct invloed op de collectie zelf, maar wel op de genetische samenstelling van het uitgiftemateriaal (zaad en indien vermenging met inzaai ook op het stekmateriaal). Om deze reden zal in een omvormingsplan van de aangrenzende bosranden voorzien moeten worden (bufferzone), ervan uitgaande dat kruisbestuiving binnen een straal van 300 meter relevant is. Ook zijn er soorten in de bosranden aanwezig die de kans op ziekten en aantastingen vergroten, waaronder de veldiep (Ulmus minor) en meidoorn (Crataegus monogyna) voor respectievelijk iepziekte en bacterievuur.

\subsubsection{Faunabeheer}

Momenteel vindt er goed overleg plaats met de faunabeheerder namens SBB en de lokale wildbeheereenheid in het onder druk houden van de wildstand in het gebied. Vooral reeën kunnen veel schade veroorzaken (vegen en vraat). Dat leidt ertoe dat vrijwel alle jonge bomen en struiken moeten worden ingekorfd. Omdat de wildbeheereenheid Flevoland (WBE) een hoger afschot mag plegen, blijft de wildvraat nog binnen de perken van wat aanvaardbaar is. Om niet te veel schade aan de collectie te veroorzaken, is het nodig om maatregelen te treffen tegen wildvraat. Er zijn drie opties:

$>$ Een raster om de genenbank (oost en west) à $€ 40$,- per strekkende meter (zwaar ree-raster). 
$>$ Alle bomen en struiken blijven korven totdat voldoende grootte en robuustheid is bereikt. Korven à $€ 7,50$ per korf voor plaatsing en exclusief periodieke controle of herstel. Bij het plaatsen van een ree-raster om het gebied kan het korven achterwege blijven.

> Combinatie van korven en verhoogd afschot (binnen de grenzen van het faunabeheerplan). Als richtlijn voor de bezetting/dichtheid van ree per 100 hectare moet deze lager dan 8 zijn. De afspraken voor het faunabeheer binnen de contouren van de genenbanklocaties Oost en West moet in het wildbeheerplan Flevoland apart worden gedefinieerd.

Van bovenstaande opties gaat de voorkeur uit naar het plaatsen van een raster om de gehele genenbank.

\subsubsection{Markering en labeling collecties}

Voor het dagelijkse beheer van de genenbank is er momenteel onvoldoende inzicht in welke accessies waar staan. De labeling van de individuele bomen, zowel in de kwekerijfase als na aanplant in het veld, moet verbeterd worden. Boom- en struikposities worden nu vastgelegd op plattegronden, maar als labels en markeringen in het veld (paaltjes) in de tijd verdwijnen, is de identiteit van accessies soms niet meer te achterhalen. Daarnaast is een goede labeling en markering in het veld nodig om snel en efficiënt uitval, vitaliteit en ziekte et cetera te monitoren. Voor de genenbank is het daarom zeer wenselijk de collecties op te nemen in een GIS-systeem en de boomposities in het veld digitaal vast te leggen met een duurzame en onzichtbare markering in het veld. Hiervoor zijn diverse systemen in de markt (vgl. met botanische tuinen, kwekerijen). Het zal nader uitgezocht moeten worden welk systeem geschikt is voor de genenbank (valt buiten het opstellen van dit implementatieplan). Daarbij doet zich nog de vraag voor of en hoe een dergelijk systeem gekoppeld moet/kan worden aan bestaande beheersystemen van SBB (CMSI of Geoweb) en het documentatiesysteem onderhouden door CGN.

\subsection{Inrichting terrein}

Ten aanzien van de inrichting van het terrein zijn twee maatregelen gewenst, namelijk exclavering van de genenbank en restauratie van recreatie- en voorlichtingsmaterialen.

\subsubsection{Exclavering genenbank Roggebotzand}

Het is wenselijk de genenbankcompartimenten binnen de boswachterij Roggebotzand te exclaveren t.o.v. het omringende bos. Beheer en bedrijfsvoering van een genenbank zijn anders dan regulier bosbeheer en vergen een verhoogde technische aanpak en frequentie. Dat kan op gespannen voet staan met de meer natuurgerichte beheermaatregelen in het kader van regulier bosbeheer. Denk bijvoorbeeld aan gewasbeschermingsmaatregelen t.b.v. de instandhouding van de collectie of bemesting in relatie tot de eisen Natuurbeschermingswet voor het omringende bosgebied. Dit is op te lossen door op basis van een tienjarige rotatie (die parallel loopt aan de beheercyclus Subsidiestelsel Natuur en Landschap (SNL)) voor iedere actuele dan wel volgende periode vrijstelling te geven voor het beheer en onderhoud van de genenbank (buiten de SNL-criteria en -normering). Indien op enig moment de genenbank wordt opgeheven, dan valt het gebied terug tot het omringende bos en wordt weer als bos ingericht. Dit heeft als consequentie dat ca. 45 ha (omvang genenbank) geen SNL-beheersubsidie toegekend zal krijgen op basis van het bosbeheertype 16 (bos met productie). De inkomstenderving voor het beheer zal dan enkele honderden euro's (ca. $€ 16,50$ per ha voor bos met productie/SNL-norm) bedragen, tenzij er een koppeling gevonden kan worden met het beheer van de genenbank als toekomstige zaadbank voor nieuw bos en landschap en het beheer. Een punt van overweging zou kunnen zijn een apart SNL-type te genereren van waaruit genenbank en zaadgaarden gefinancierd worden, aangezien ze de 'kraamkamers' van zowel ons bos als natuur en landschap vormen.

\subsubsection{Voorlichting en recreatie}

De genenbank Roggebotzand is opengesteld voor publiek. Met de inrichting is hiermee rekening gehouden. Zo is er in het westelijke deel een wandelroute uitgezet die begeleid wordt door kleine informatiepanelen. Het oostelijke deel is functioneler ingericht. Hier zijn geen bijzondere 
wandelroutes. Het is wenselijk om de routing in het westelijke deel te herzien en waar nodig aan te passen en te verbeteren. Daarnaast is de informatievoorziening technisch en inhoudelijk verouderd. Ook het recreatiemeubilair (banken) moet vervangen worden. De genenbank (en met name West) geniet echter veel belangstelling, vooral ook onder rustzoekers. Gezien de actuele publieke belangstelling voor bos en bomen is een verbetering van de route in het westelijke deel gewenst. Concreet gaat het om de volgende maatregelen:

$>$ Routing waar nodig aanpassen en verbeteren;

$>$ Informatievoorziening vervangen en inhoudelijk aanpassen;

> Informatievoorziening koppelen aan modernere belevingsvormen, bv. aan QR-codes;

$>$ Recreatiemeubilair vervangen.

\section{$2.4 \quad$ Fasering}

Hieronder wordt de planning in de tijd gegeven van de benodigde maatregelen t.a.v. verbetering van de groeiplaats, inrichting en operationeel beheer van de genenbank in Roggebotzand.

Voor maatregelen als herstel van watergangen is al gestart met voorbereidend werk. Herstel van de waterhuishouding betreft de gehele boswachterij en niet alleen de genenbank. Het lijkt daarom logisch om ook in het kader van klimaatslim bos- en natuurbeheer de gewenste verbetermaatregelen voor de hele boswachterij uit te voeren en dit apart te budgetteren. Twee maatregelen hebben een langere voorbereidings- en planningsfase nodig, omdat ze bestuurlijk meer voorwerk en tijd zullen vragen. Dit betreft maatregelen voor de dijkse kwelsloot (profilering en waterafvoerend vermogen) in verband met waterveiligheid (dijk) en het eventueel kunnen plaatsen van een hevel (Vossemeer-Boswachterij) voor het kunnen inlaten van gebiedsvreemd water. Maatregelen als uitrasteren van de genenbank (wildschadepreventie) en het eventueel geheel exclaveren van de genenbank t.o.v. de bosbestemming zal intern binnen Staatsbosbeheer nog een overlegtraject moeten doorlopen, waardoor de planningsen voorbereidingsfase langer duurt. Het streven is om in 2024-2025 het herstel- en verbeterplan uitgevoerd te hebben en operationeel te hebben in het dagelijks beheer.

Tabel 2.1 Fasering werkzaamheden t.a.v. verbetering van groeiplaats, inrichting en beheer van de genenbank.






\subsection{Kosten en investeringen}

Hieronder wordt een eerste kostenraming gegeven van de eenmalige verbeter- en herstelmaatregelen, gebaseerd op kostennormen en ervaringscijfers. Meer precieze kostencalculaties en offertes zullen moeten uitwijzen of deze raming voldoende stevigheid biedt.

Tabel 2.2 Samenvatting investeringsmaatregelen en eenmalige kosten voor de genenbank Roggebotzand. NB Het betreft hier eenmalige kosten t.o.v. het reguliere beheer van de genenbank.

\begin{tabular}{|c|c|c|c|c|c|c|}
\hline Onderdeel & Nummer & Maatregel & Eenheid & $\begin{array}{l}\text { Kosten } \\
\text { eenheid }\end{array}$ & $\begin{array}{l}\text { Totaal } \\
\text { eenheid }\end{array}$ & Totale kosten \\
\hline \multirow[t]{3}{*}{ Bodem } & 1.1 & $\begin{array}{l}\text { Bodemkartering/beschrijving opstellen }+ \\
\text { mechanisch bodemonderhoud advies }\end{array}$ & $\mathrm{Ha}$ & 1000 & 45,16 & 45.000 \\
\hline & 1.2 & $\begin{array}{l}\text { Bemestingsadvies incl. org. stofgehalte en } \\
\text { vochtleverend vermogen }\end{array}$ & $\mathrm{Ha}$ & 500 & 45,16 & 25.000 \\
\hline & 1.3 & $\begin{array}{l}\text { Diepspitten en verbreken/mengen storende } \\
\text { lagen voor ten minste } 25 \text { ha (genenbank } \\
\text { West) }\end{array}$ & $\mathrm{Ha}$ & 1000 & 25 & 25.000 \\
\hline \multirow[t]{7}{*}{ Water } & 2.1 & $\begin{array}{l}\text { Plaatsen hevel locatie Vossemeerdijk kavel } \\
\text { N81 }\end{array}$ & & & & p.m. ${ }^{4}$ \\
\hline & 2.2 & $\begin{array}{l}\text { Plaatsen regelbare stuwen/stuwputten, } \\
\text { overige kunstwerken waaronder plateaus } \\
\text { (oost) voor tijdelijke pompen langs de }\end{array}$ & ST & 2500 & 14 & 35.000 \\
\hline & & $\begin{array}{l}\text { Roggebottocht voor het doorpompen van } \\
\text { water naar genenbank West }\end{array}$ & ST & 2000 & 2 & 4.000 \\
\hline & 2.3 & Herprofileren, opschonen (schouwsloten) & M1 & 10 & 20000 & 200.000 \\
\hline & 2.4 & $\begin{array}{l}\text { Op hoogte stellen duikers en evt. } \\
\text { vervangen }\end{array}$ & ST & 1000 & 14 & 7.000 \\
\hline & 2.5 & $\begin{array}{l}\text { Verbinden slotensysteem oost en west via } \\
\text { Roggebotweg. Moet in overleg met de } \\
\text { wegbeheerder (Dronten) }\end{array}$ & M1 & 3 & 10000 & 30.000 \\
\hline & 2.6 & Herstel/profileren dijkse kwelsloot & & & & p.m. ${ }^{5}$ \\
\hline Fauna & 3 & Reeën-raster zwaar & M1 & 40 & 6200 & 250.000 \\
\hline Recreatie & 4 & Stelpost informatievoorziening - QR-code & & & & 50.000 \\
\hline $\begin{array}{l}\text { Registratie en } \\
\text { monitoring } \\
\text { collecties }\end{array}$ & 5 & $\begin{array}{l}\text { Gps-registratie-identificatie systeem } \\
\text { (tracers) - } 1 \text { punt per accessie }\end{array}$ & & & PM & 100.000 \\
\hline $\begin{array}{l}\text { Project- } \\
\text { begeleiding } \\
(15 \%)\end{array}$ & & & & & & 110.000 \\
\hline
\end{tabular}

C 881.000,-

\subsection{Uitvoeringsscenario's investeringsmaatregelen}

Om een keuze op basis van het bovenstaande kostenoverzicht/investeringen te rechtvaardigen, zijn drie keuzescenario's t.a.v. het aanhouden van de locatie Roggebotzand als genenbank te benoemen:

$>$ Niets doen: Primair betekent dit een verdere verslechtering van de plaatselijke situatie en groeiomstandigheden van de collectie. In toenemende mate zullen extra kosten moeten worden gemaakt m.b.t. water geven tijdens perioden van droogte en hittestress. De kosten hiervoor bedroegen over de afgelopen jaren gemiddeld $€ 35.000$ per jaar. Daarnaast zullen er ook

4 p.m. - plaatsen hevel N81 kan alleen in overleg met het waterschap. Het betreft inlaat van gebiedsvreemd water dat een bestuursbesluit en evt. een inspraakprocedure vergt in samenwerking met Rijkswaterstaat als eigenaar/beheerder van het buiten-boezemwater (Vossemeer).

5 p.m. - Herstel en profileren dijkse kwelsloot hangt mede samen met de veiligheid van het dijklichaam en de eisen die het waterschap stelt. 
facultatieve maatregelen moeten worden getroffen in zeer natte perioden (late winter-vroeg voorjaar) om wortelschade en daarmee aantasting van de vitaliteit te voorkomen. De bodemkundige situatie is verre van optimaal en daarmee ook de hele mineralenbalans en het organischestofgehalte. Facultatieve bemesting scoort minder goed dan een uit- en afgewogen bemestingsprogramma. Voor het duurzaam kunnen oogsten van stek en zaad is een goede teeltsituatie nodig die vergelijkbaar is met een boomkwekerij. Een en ander vergt veel energie van de planten, vooral als de groeiplaatsomstandigheden niet op orde zijn. Ten slotte kunnen we onze opdracht m.b.t. instandhouding en ontwikkeling van het unieke genetische erfgoed op de langere termijn niet realiseren. Gedane investeringen en kosten vanaf 2006 zullen dan (deels) moeten worden afgeschreven en teniet worden gedaan. Dat gaat om vele miljoenen euro's.

> Verplaatsen genenbank: Technisch zou dit misschien de optimaalste optie zijn. Opzet van een nieuwe genenbank in een kwekerij gelijkende situatie biedt voordelen: rationele indeling van de gewassen, goede groeiplaatsomstandigheden, goed ontsloten, continue verpleging, moderne teelttechnieken en technische hulpmiddelen. Anderzijds betekent dit een desinvestering t.o.v. de gedane investeringen en kosten m.b.t. de huidige genenbanklocatie. Ook is het een dure optie aangaande grondverwerving en het kopiëren van de bestaande collectie naar een nieuwe groeiplaats. Daarnaast is verplanten alleen voor een beperkt aantal soorten mogelijk in verband met risico's van uitval en de zeer hoge kosten die eraan verbonden zijn. Grondverwerving van derden in eigendom of pacht/huur brengt hoge kosten met zich mee (binnen SBB wordt niet met grondkosten over eigen grond gerekend). Voor verplaatsen van de genenbank moet rekening gehouden worden met de volgende kosten (schatting):

- Verwerven kwekerijgrond. De kostprijs van 1 ha kwekerijgrond (index Noord-Nederland) bedraagt ca. $€ 65.000$ per ha. Voor de totale genenbank betekent dit (afgerond 50 ha) $€$ 3.250.000. Indien gepacht wordt, zouden de kosten op basis van $10 \%$ van de eigendomswaarde $€ 325.000$ per jaar totaal voor 50 ha bedragen.

- Verwerven of huren bedrijfsgebouw met ten minste een huurwaarde van $€ 50.000$ per jaar of koop circa ten minste $€ 500.000$.

- Het opnieuw stekken of 'verhuizen' van de bestaande collectie ca. $€$ 2.000.000.

- Overgangsbeheer huidige locatie en nieuwe locatie, tijdelijk dubbele kosten; uitgaande van $€ 250.000$ per jaar is dat dan $€ 1250.000$ gedurende de eerste 5 jaar.

- Ontruimen huidige locatie en bos inplanten à $€ 20.000$ per ha is $€ 1.000 .000$.

Bij dit scenario dienen de investeringen van 2006 eveneens afgeschreven te worden. De totale kosten voor verplaatsen van de collectie naar kwekerijgrond van derden worden op $€ 8000.000$ geschat; dit wordt als financieel onhaalbaar geacht.

$>$ Verbeteren en investeren in de genenbank Roggebotzand conform kostentabel 2.2: In deze optie worden de kosten in tabel 2.2 gemaakt om verbeteringen en herstelmaatregelen in de genenbank Roggebotzand door te voeren met als doel de huidige locatie van de collectie inheems-autochtone bomen en struiken te kunnen behouden. Vanaf 2006 hebben zowel investerings- als exploitatieuitgaven plaatsgevonden, gefinancierd met maatschappelijk geld en in opdracht van het Ministerie van LNV. Er staat inmiddels een flink deel van de te borgen en te bewaren soorten. Naast het conserveren, vindt er ook oogst plaats en door eerste facultatieve maatregelen zijn er lichte verbeteringen merkbaar in de relatie groeiplaats en gewasontwikkeling. De verbetermaatregelen die met name moeten worden getroffen aan bodem, waterhuishouding en voedingstoestand zijn fors van aard door de schaal, maar anderzijds ook overzichtelijk. De kwaliteit van de groeiplaats en het onderhoud ervan bepaalt de kwaliteit van het gewas en als resultante daarvan de oogst. De kosten in het kader van calamiteitenbestrijding zoals droogte en hittestress bedragen gemiddeld $€ 35.000$ per jaar. Met de verbeter- en herstelmaatregelen wordt verwacht dat deze kosten kunnen worden voorkomen dan wel genivelleerd. 


\section{Soortensamenstelling en opbouw collecties}

\subsection{Opbouw en prioritering van collectie en soortensamenstelling}

In de eerder uitgevoerde evaluatie van de genenbank (Buiteveld and Copini, 2019) zijn 52 soorten als prioritair aangewezen (van de 98 beschouwde inheemse boom- en struiksoorten) voor opname in de genenbank Roggebotzand. Van deze 52 soorten staan er momenteel 35 in de genenbank met het aantal accessies variërend tussen 10 en 172, en 6 soorten met minder dan 10 accessies. Daarnaast staan er 17 complementaire soorten, die gebruikt worden voor zaadproductie en ook drie soorten die beschouwd kunnen worden als archeofieten of waarvan de autochtone status onzeker is. In totaal staan er circa 4700 accessies met 25.000 bomen en struiken in de genenbank (zie ook Tabel 1, Buiteveld and Copini, 2019).

In dit hoofdstuk wordt de collectieopbouw van de genenbank uitgewerkt in twee scenario's, met een planning in tijd. In het eerste scenario wordt de genenbank niet verder geoptimaliseerd, maar wordt enkel de huidige collectie minimaal in stand gehouden. In het tweede scenario wordt de collectie geoptimaliseerd volgens de aanbevelingen van het rapport. Beide scenario's worden uitgewerkt in twee varianten. Voor alle varianten worden de kosten doorberekend.

\subsection{Scenario's genenbankcollectie 'Minimaal' versus 'Optimaal'}

\section{Scenario 1 'Minimaal'}

Binnen dit scenario worden de huidige collecties bestaande uit 35 prioritaire soorten, 17 complementaire soorten en 3 overige collecties (Mespilus germanica, Salix triandra, Salix viminalis) in stand gehouden, maar er zal geen verdere uitbreiding plaatsvinden van prioritaire soorten of accessies. Binnen dit scenario worden twee varianten geschetst.

Binnen scenario $1 \mathrm{~A}$ wordt het huidig aantal kopieën van alle accessies in stand gehouden. Het gaat om 2.664 accessies met 14.008 individuen van prioritaire soorten, 1.905 accessies met 10.351 individuen van complementaire soorten en 160 accessies en 937 individuen van de overige collecties van Mespilus germanica, Salix triandra, Salix viminalis.

Binnen scenario 1B wordt ervan uitgegaan dat 5 kopieën/individuen per accessie nodig zijn voor bomen, grote struiken en 10 kopieën/individuen voor kleine (dwerg)struiken en moerstoven om de veiligheid van de collectie te borgen en voldoende zaad/stek te produceren. In totaal betreft het $17.485,10.945$ en 1.345 individuen van respectievelijk prioritaire soorten, complementaire soorten en overige collecties.

\section{Scenario 2 'Optimaal'}

Binnen dit scenario wordt de huidige collectie geoptimaliseerd (zie paragraaf 3.3) door indien nodig nieuwe accessies aan de collectie van al opgenomen soorten toe te voegen en 52 prioritaire soorten op te nemen in de genenbank locatie Roggebotzand (of Lelystad/Hollandse Hout-Zuid). In totaal gaat het om opname van 19 nieuwe soorten die momenteel niet of met minder dan 10 accessies vertegenwoordigd zijn, incl. Fraxinus excelsior \& Genista anglica (Tabel 3.1). Van sommige van deze prioritaire soorten, zoals Pyrus pyraster, zijn de autochtone genenbronnen zo schaars, dat het slechts enkele individuen betreft. Binnen dit scenario worden twee varianten geschetst en doorberekend. Binnen scenario 2A wordt voorgesteld om alle 52 prioritaire soorten in de levende collectie in 
Roggebotzand (of Lelystad/HHZ) op te nemen. De collectie van prioritaire soorten wordt dan uitgebreid van 2.664 naar 3.448 accessies met in totaal 23.955 individuen.

Binnen Scenario 2B worden ook alternatieve conserveringsmethoden meegenomen in de berekening voor soorten die minder geschikt of ongeschikt zijn voor de genenbank. Soorten die minder of ongeschikt zijn voor opname in de genenbank Roggebotzand of Lelystad zijn: Andromeda polifolia, Arctostaphylos uva-ursi, Daphne mezereum, Erica cinerea, Genista germanica, Genista pilosa, Genista tinctoria \& Myrica gale, Vaccinium uliginosum, omdat de groeiomstandigheden ongunstig zijn. Dit geldt ook voor Genista anglica, Daphne mezereum en in mindere mate voor Juniperus communis \& Taxus baccata die al zijn opgenomen in de genenbank of in het geval van Daphne mezereum zijn verplaatst naar een locatie in het Gerendal. Daarnaast zijn veldcollecties voor Fraxinus excelsior en Ulmus glabra ongeschikt, vanwege respectievelijk de essentaksterfte en iepziekte. Alternatieven voor Roggebotzand voor deze soorten zijn 1) ex-situcollecties op locaties elders in Nederland; 2) collectie aanleggen op een kwekerij of 3) zaadbank collecties aanleggen (zie ook paragraaf 4.4). In dit scenario staan er minder soorten en accessies van prioritaire soorten in de genenbank Roggebotzand of Lelystad ten opzichte van scenario 2A (2.960 accessies met 18.990 individuen), waarbij voor bovenstaande soorten voor een alternatieve methode wordt gekozen.

Tabel 3.1 Overzicht van 19 prioritaire soorten die momenteel niet of met minder dan 10 accessies vertegenwoordigd zijn in de genenbank. Fraxinus excelsior is in dit overzicht opgenomen gezien de grote sterfte en Genista anglica is toegevoegd gezien de slechte vitaliteit in de genenbank.

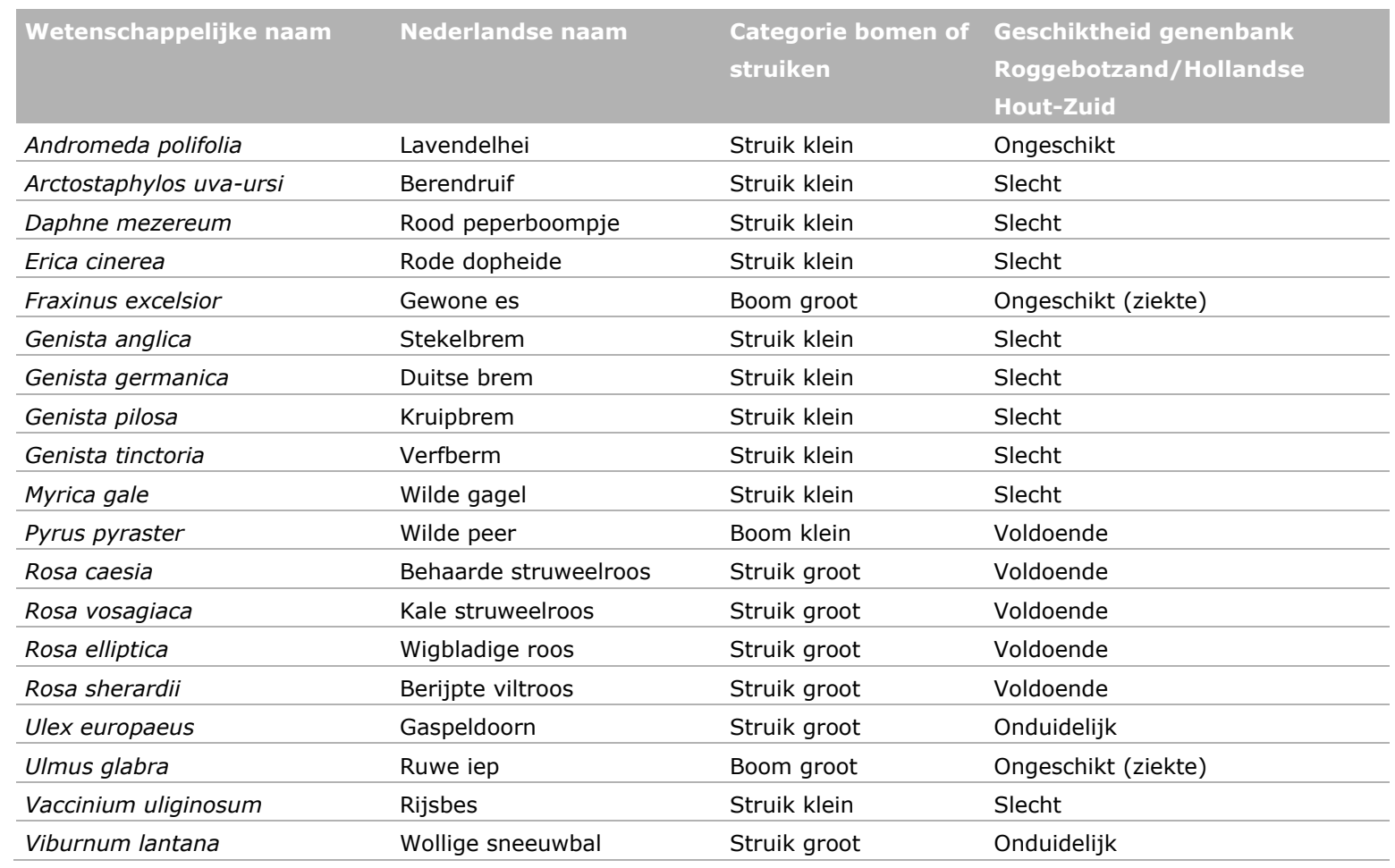




\subsection{Optimalisatie en uitbreiding van de collectie in scenario 2}

Voor optimalisatie en uitbreiding van de collectie is voor verschillende soorten de opnamestrategie geanalyseerd, waarbij voor zover mogelijk verspreidingsgegevens in GIS zijn gebruikt (zie kader). Op basis van deze analyse en gesprekken met experts is de uitbreiding per soort geschat (Bijlage 2). Hieronder worden enkele soorten en soortgroepen nader toegelicht.

\subsubsection{Optimalisatie accessiesamenstelling}

De werkwijze wordt in Figuur 3.2 ter illustratie weergegeven voor de 155 accessies van Crataegus laevigata, 42 accessies van Rosa arvensis, 15 accessies van Tilia platyphylos en 51 accessies van Acer campestre. Vindplaatsen (potentiële accessies) zijn weergegeven vanuit de GIS-laag van de Atlas Groen Erfgoed. Als voorbeeld zien we dat accessies van Crataegus laevigata, een soort die voornamelijk in het oosten van het land voorkomt, ruimtelijk van Groningen tot en met Limburg zijn verzameld. Het overgrote deel van de accessies komt uit gebieden met de waardering 'zeer waardevol' of 'waardevol' volgens de Atlas Groen Erfgoed. Eventueel kunnen de meidoorns uit Friesland aan de collectie worden toegevoegd (max. 10 accessies). Een ander voorbeeld is Rosa arvensis, een kwetsbare soort die nog op enkele groeiplaatsen in Limburg voorkomt. De 42 accessies van Rosa arvensis komen uit gebieden die als 'zeer waardevol' en 'waardevol' gewaardeerd worden volgens de Atlas Groen Erfgoed. Vindplaatsen in het zuidwestelijke deel van Zuid-Limburg (Savelsbos, Cotessen en het Bunderbos) en De Doort zijn ondervertegenwoordigd (uitbreiding max. 10 accessies). Waar de collecties van Crataegus laevigata, Rosa arvensis \& Acer campestre (Figuur 3.1) laten zien dat voor deze soorten al ruimtelijk goed verzameld is door het land, bestaat de collectie Tilia platyphyllos daarentegen slechts uit enkele accessies uit twee gebieden (Savelsbos en Reicholterbos). Aanvulling met materiaal uit Zuid-Limburg en Oost-Nederland heeft hier prioriteit.

\section{Wilgencollectie}

De huidige wilgencollectie in Roggebotzand bestaat uit 10 soorten, waaronder 2 soorten waarvan de autochtone status onzeker is of die tegenwoordig als archeofiet beschouwd worden (Salix triandra, S. viminalis). Vijf hiervan worden gezien als prioritaire soorten om op te nemen in de veldcollectie: S. pentandra, S. purpurea, S. aurita, S. fragilis en S. repens (uitsluitend binnenlands materiaal). De overige soorten zijn complementair, deze collecties zijn handig voor stekproductie. De collectie van S. repens en S. pentandra is compleet en behoeft geen verdere uitbreidingen. Bij de overige soorten gaat het om kleine aanvullingen uit nieuwe locaties. De S. purpurea-collectie is onevenwichtig opgebouwd met de helft van de accessies afkomstig uit één populatie, waarbinnen mogelijk nauw verwante en klonale individuen. De wilgencollecties in voornamelijk Roggebotzand-West zijn vervuild met zaailingen, die zijn ingewaaid van wilgen uit de bosranden of nabije omgeving. Daarnaast ondervinden de wilgenmoerstoven (behalve $S$. pentandra) veel concurrentie van onkruid. Beide problemen zorgen voor veel onderhoud; daarnaast wordt door de inzaai van andere wilgen ook de stekproductie 'vervuild'. Van belang is het beheer van deze collecties aan te passen, zodat soortzuivere collecties in stand gehouden worden. Optimalisatie betekent hier: bij vervanging van collecties of verplaatsing naar de Lelystand-locatie, de moerstoven op $2 \times 2 \mathrm{~m}$ afstand zetten met worteldoek eronder (zogenaamde 'kwekerij'-beheer). Op deze wijze kan inzaai van andere wilgen en onkruidvorming beter onder controle gehouden worden en blijven de individuele stoven identificeerbaar. 

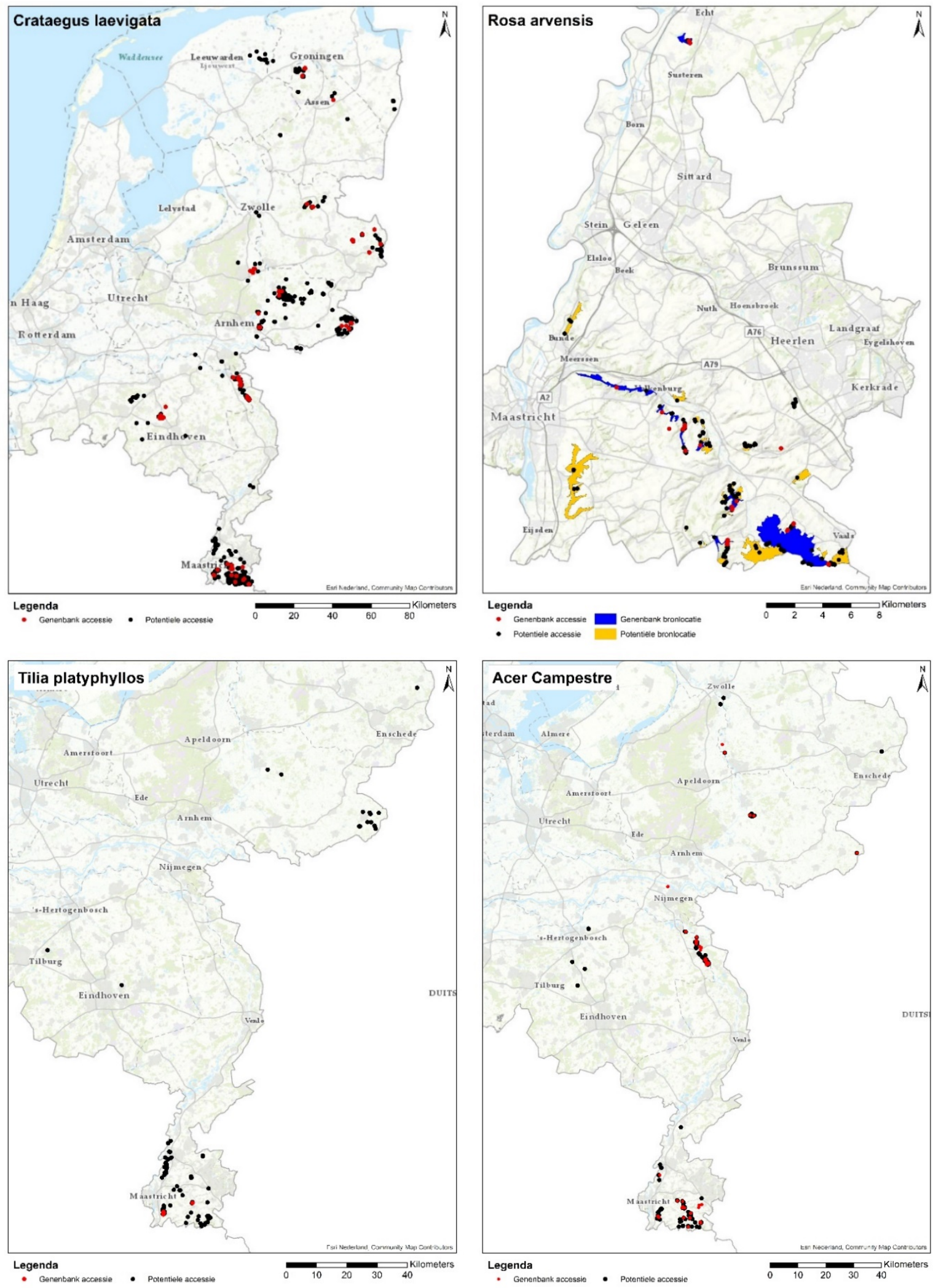

Figuur 3.1 Accessies (rood) van Crataegus laevigata, Rosa arvensis, Tilia platyphyllos \& Acer campestre in de genenbank en potentiële accessies (zwart) op basis van het GIS-bestand van de Atlas Groen Erfgoed. Crataegus laevigata komt voornamelijk voor in Oost-Nederland, terwijl Rosa arvensis een soort is van Limburg. Tilia platyphyllos en Acer campestre komen voornamelijk voor in zuidelijke en oostelijke provincies van Nederland. 


\section{Rozencollectie}

Het geslacht Rosa is een taxonomisch complex geslacht. De grootste problemen qua taxonomie en herkenning doen zich voor in de hondsrozen (sectie Caninae), vanwege een aantal bijzondere kenmerken als polyploïdie, de 'canina meiose', het vermogen van soorten om onderling te kruisen, en de overwegend matroclinale overerving. Recentelijk is op basis van verspreidingsgegevens, kennis over de taxonomie en genetische informatie een analyse gemaakt omtrent de vraag welke inheemse soorten/hybriden van het geslacht Rosa in de genenbank in Roggebotzand/Lelystad opgenomen dienen te worden en van welke soorten het genenmateriaal eventueel in situ voor de lange termijn geborgd kan worden (zie Schaminee et al., 2020). Dit advies over optimalisatie dan wel uitbreiding van rozencollecties is verwerkt in Tabel 3.1.

\section{Box 1 Betere ontsluiting GIS-data}

Belangrijke databestanden voor de ontwikkeling van de genenbank zijn de Atlas van het landschappelijk groen erfgoed van Nederland, hierna te noemen Atlas Groen Erfgoed (Maes, 2016), en autochtone opstanden van de Rassenlijstbomen. De Atlas Groen Erfgoed toont een verkort overzicht van de veldopnamen, uitgevoerd in de periode 1992-2020 door het Ecologische Adviesbureau Maes, Bronnen (tot 2003) en het Ecologisch Adviesbureau van Loon en uitgebracht door de Rijksdienst voor het Cultureel Erfgoed. Deze goed toegankelijke landsdekkende dataset, te raadplegen via https://www.landschapinnederland.nl/kaart-groen-erfgoed, geeft niet de achterliggende veldopnamen weer, maar toont geaggregeerde data binnen grootschalige landschapsgebieden en geeft over deze gebieden een waardering op een schaal van $A$ (zeer waardevol) tot $C$ (vrij waardevol). In totaal worden er zes klassen onderscheiden ( $A, A / B, B, B / C$ \& $C$ ) naast kansrijke, niet-geïnventariseerde gebieden). Naast de polygonen van gebieden, zijn er ook ca. 50.000 individuen als puntlocatie opgenomen.

Voor verdere ontwikkeling van de genenbank is het van belang dat het CGN \& Staatbosbeheer ook gebruik kunnen maken van (i) de beoordelingen van opstanden en struwelen die niet in de Atlas Groen Erfgoed zijn ontsloten en (ii) de achterliggende veldopnamen. In de achterliggende veldopnamen wordt ook de autochtoniteit van boom- en struikpopulaties beoordeeld in drie categorieën van: (a) vrijwel zeker autochtoon), (b) waarschijnlijk autochtoon en (c) mogelijk autochtoon. Niet-autochtone bomen en struiken worden aangegeven met $\mathrm{p}$ (aangeplant) en s (spontaan). Oudbos-indicatoren in de kruidlaag worden kwalitatief vermeld. Deze data zouden beschikbaar kunnen worden gesteld binnen de Atlas Groen Erfgoed of de Nationale Databank Flora en Fauna (NDFF). Hiervoor dienen de veldopnames geüniformeerd te worden en gekoppeld binnen GIS.
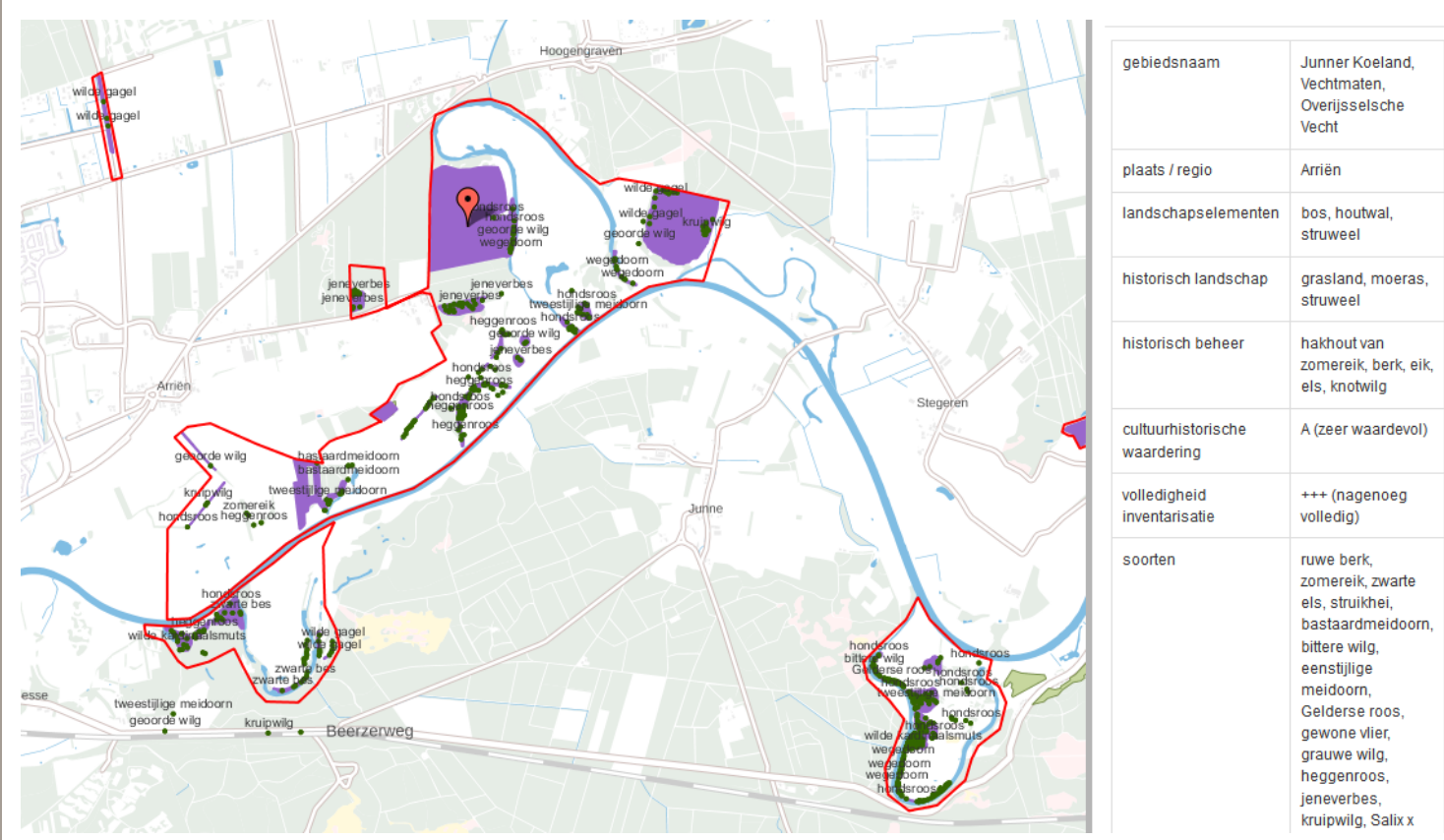

Voorbeeld uit de Atlas Groen Erfgoed met locatie nabij Ommen. 


\subsubsection{Uitbreiding prioritaire soorten}

In totaal staan 19 prioritaire soorten (Tabel 3.1, inclusief Daphne mezereum) momenteel niet in de genenbank (of met minder dan 10 gezonde accessies). Voor deze soorten dient een collectie samengesteld te worden (voor rozen zie ook het rapport Schaminee et al. (2020)). Voor de meeste soorten zijn potentiële accessies redelijk in beeld, o.a. via de Atlas Groen Erfgoed (Figuur 3.2). Voor dwergstruiken zoals Genista tinctoria en Genista pilosa hebben we niet een compleet beeld van autochtone genenbronnen in Nederland. In de komende jaren zouden autochtone populaties van deze soorten opgenomen kunnen worden in de Atlas Groen Erfgoed (zie Box 1) om de opbouw van collecties te faciliteren.
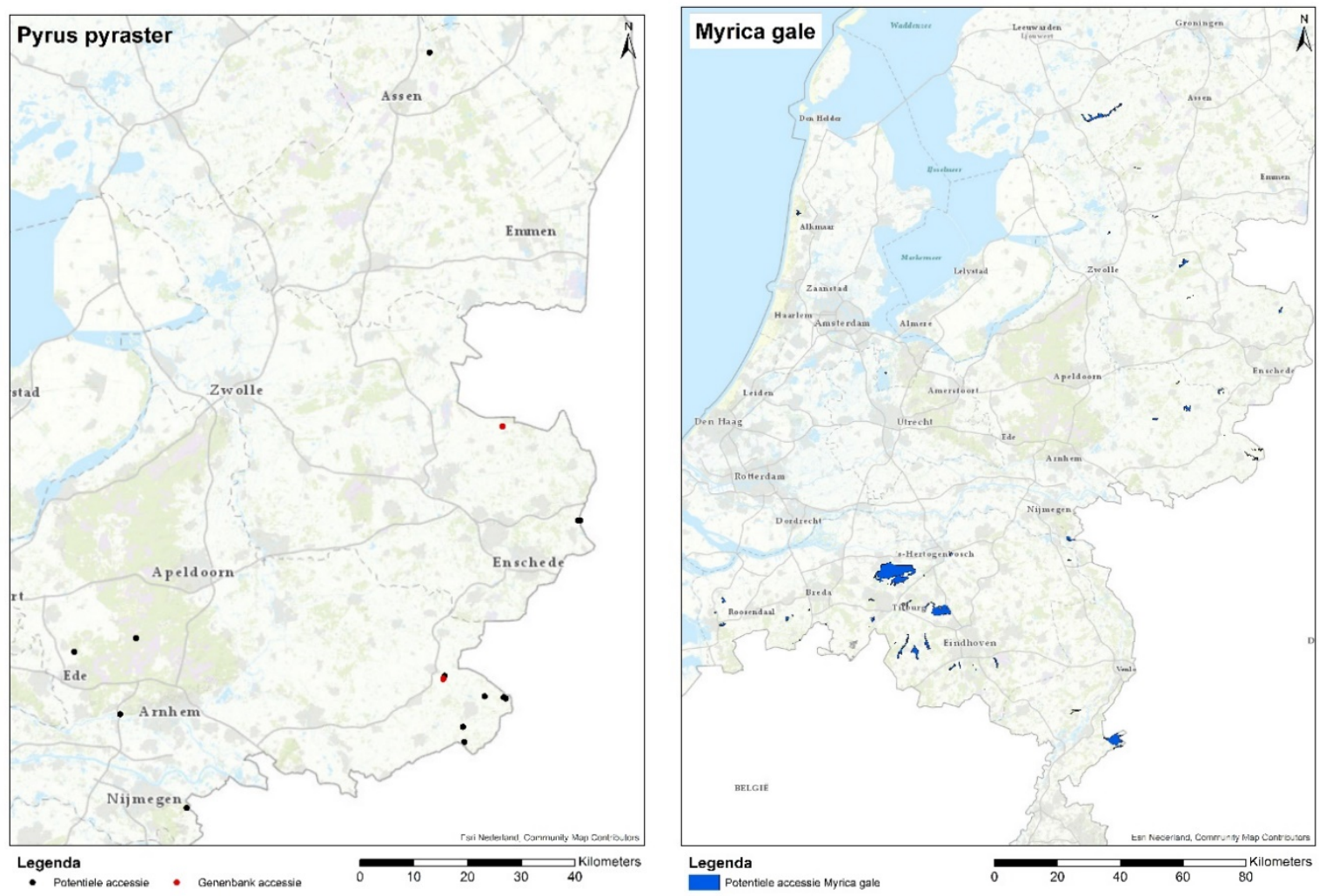

Figuur 3.2 Accessies (rood) van Pyrus pyraster in de genenbank en potentiële accessies (zwart) en vindplaatsen van Myrica gale (blauw) op basis van het GIS-bestand van de Atlas Groen Erfgoed.

\section{$3.4 \quad$ Fasering}

In geval van scenario 1 (variant A en B) wordt de collectie niet geoptimaliseerd of uitgebreid. De werkzaamheden en kosten voor instandhouding en vervanging van accessies die dreigen uit te vallen, zijn vergelijkbaar tussen de jaren. Voor struiken geldt dat de collecties na ca. 20 jaar vernieuwd moeten worden en voor bomen is dit na 30 à 40 jaar. Moerstoven worden in de regel om de 15 jaar vervangen.

Voor scenario 2 (variant A en B) wordt voorgesteld in de komende 5 jaar collecties op te bouwen van prioritaire soorten die nu niet in de genenbank vertegenwoordigd zijn (zie Bijlage 2) en daarnaast de accessiesamenstelling te optimaliseren van Tilia platyphyllos en Salix purpurea waarvan de collecties nu zeer onevenwichtig zijn opgebouwd. Voor sommige soorten geldt dat autochtone genenbronnen in kaart moeten worden gebracht op basis van oudere inventarisaties, terwijl van andere soorten direct nieuwe accessies kunnen worden verzameld en vermeerderd. Het is vanuit praktische overwegingen aan te bevelen om per seizoen een aantal soorten op te pakken, zodat materiaal per soort tegelijk op de kwekerij vermeerderd kan worden in plaats van de vermeerdering te spreiden over vele jaren. Van 
snelgroeiende soorten zoals Salix purpurea kan binnen enkele jaren een nieuwe collectie worden aangeplant, terwijl dit voor bomen in het algemeen na 5-7 jaar kan.

Op langere termijn (5-10 jaar) kunnen de collecties van al aanwezige soorten compleet gemaakt worden. Aanbevolen wordt om dit te doen op hetzelfde moment dat de collecties periodiek vernieuwd worden.

Tabel 3.2 Globale fasering scenario $2 B$ voor opname en uitbreiding prioritaire soorten in de genenbank locatie Roggebotzand, Hollandse Hout-Zuid of Lelystad-Noord.

\begin{tabular}{|c|c|c|c|c|c|c|}
\hline $\begin{array}{l}\text { Wetenschappelijke } \\
\text { naam }\end{array}$ & Nederlandse naam & $\begin{array}{l}\text { Autochtone } \\
\text { genen- } \\
\text { bronnen } \\
\text { selecteren }\end{array}$ & $\begin{array}{l}\text { Verzamelen } \\
\text { stek voor } \\
\text { vegetatieve } \\
\text { vermeerdering }\end{array}$ & Kweek & Aanplant & $\begin{array}{l}\text { Locatie } \\
\text { genenbank }\end{array}$ \\
\hline Pyrus pyraster & Wilde peer & 2021 & $2021 / 2022$ & $2022 / 26$ & 2026 & $\mathrm{RBZ} / \mathrm{HHZ}$ \\
\hline Salix aurita & Geoorde wilg & 2021 & $2021 / 2022$ & 2022 & 2023 & HHZ/Lelystad N \\
\hline Salix fragilis & Kraakwilg & 2021 & $2021 / 2022$ & 2022 & 2023 & HHZ/Lelystad N \\
\hline Salix purpurea & Bittere wilg & 2021 & $2021 / 2022$ & 2022 & 2023 & HHZ/Lelystand $\mathrm{N}$ \\
\hline Rosa caesia & Behaarde struweelroos & 2022 & $2023 / 2024$ & $2023 / 25$ & $2025 / 26$ & $\mathrm{RBZ} / \mathrm{HHZ}$ \\
\hline Rosa vosagiaca & Kale struweelroos & 2022 & $2023 / 2024$ & $2023 / 25$ & $2025 / 26$ & $\mathrm{RBZ} / \mathrm{HHZ}$ \\
\hline Rosa elliptica & Wigbladige roos & 2022 & $2023 / 2024$ & $2023 / 25$ & $2025 / 26$ & $\mathrm{RBZ} / \mathrm{HHZ}$ \\
\hline Rosa sherardii & Berijpte viltroos & 2022 & $2023 / 2024$ & $2023 / 25$ & $2025 / 26$ & $\mathrm{RBZ} / \mathrm{HHZ}$ \\
\hline Tilia platyphyllos & Zomerlinde & 2021 & $2021 / 2022$ & $2022-2026$ & 2026 & $\mathrm{RBZ} / \mathrm{HHZ}$ \\
\hline Ulex europaeus & Gaspeldoorn & 2022 & $2023 / 2024$ & $2023 / 25$ & $2025 / 26$ & Nog onbekend \\
\hline Viburnum lantana & Wollige sneeuwbal & 2022 & $2023 / 2024$ & $2023 / 25$ & $2025 / 26$ & Nog onbekend \\
\hline
\end{tabular}

\subsection{Berekening kosten voor collectie beheer}

De kosten voor het aanleggen en beheren zijn berekend op basis van een maatregelenpakket dat in overleg met SBB is vastgesteld. Het pakket bestaat uit werkzaamheden die zijn gekoppeld aan een bewerkingspercentage en een frequentie (zie ook Bijlage 3). Dit is gekoppeld aan kostennormen, zoals die voor 2020 zijn vastgesteld (Van Raffe en De Jong, 2020). Onderstaande tabel geeft een beschrijving van de uitgangspunten. De kosten zijn exclusief btw. Er is gerekend met een toeslag van $20 \%$ voor overhead op de directe kosten voor de uitvoering. Er is van uitgegaan dat het werk in voldoende omvang uitgevoerd kan worden, waarbij alleen per dag of dagdeel aan- en aflooptijden van toepassing zijn. Er is geen rekening gehouden met aanvoer van mensen en machines (uitgegaan van lokaal werk).

De maatregelen bestaan uit aanplant (terreinvoorbereiding, aankoop plantmateriaal, planten, boompalen plaatsen, bemesten en watergeven), onderhoud (snoeien, takken versnipperen, bemesten, onkruidbestrijding, maaien) en vervanging (aanplant, incl. verwijderen oude exemplaren). Bij het versnipperen is ervan uitgegaan dat de houtsnippers niet afgevoerd worden, maar in het terrein worden toegepast. Stamhout wordt 'om niet' afgevoerd (wordt in de houtoost van de boswachterij meegenomen als biomassa of stamhout, afhankelijk van de soort en kwaliteit). De uitgangspunten zijn weergegeven in tabel 3.3. De berekende kosten zijn in Tabel 3.4 opgenomen.

Er is van uitgegaan dat naast het oppervlak aan beplanting $20 \%$ terrein (25\% toeslag op oppervlak van beplanting) nodig is voor o.a. toegankelijkheid (paden). Dit terrein wordt geklepeld met een frequentie van 5 keer per jaar.

Het beheer van de genenbank is zeer specifiek. De variatie aan soorten en groei- en verschijningsvormen is groot. Om de kosten voor beheer van de genenbank inzichtelijk te maken, zijn de soorten opgedeeld in 5 categorieën: (1) boom groot, (2) boom klein, (3) struik groot \& (4) struik klein met elk hun eigen onderhoudskosten. Daarnaast is aangegeven of de collecties als (5) moerstoof voor oogst van stekmateriaal worden beheerd (Figuur 3.3). 
Het beheer is afgestemd met Staatsbosbeheer. Het blijft echter een ruwe benadering, omdat er geen standaardbeheer is voor dergelijke terreinen. Realisatie- of nacalculatiecijfers van het huidige beheer zijn niet verkregen, zodat een vergelijking daarmee niet mogelijk is. Van sommige activiteiten wijkt het doorgerekende beheer af van wat tot voor kort werd toegepast. Zo wordt nu meer uitgegaan van schoffelen tegen onkruid bij kleine struiken en bij 30\% van de grote struiken, in tegenstelling tot (bos)maaien, omdat blijkt dat bij maaien de druk van het onkruid te groot blijft en er ook nevenschade aan de aanplant kan ontstaan. Er is uitgegaan van mechanische onkruidbestrijding, aangezien hiermee de meeste ervaring is. Bestrijding met heet water is wellicht ook mogelijk, maar daarvan is nog onvoldoende bekend over de werking en kosten. ${ }^{6}$

$\mathrm{Er}$ is aan verschillende werkzaamheden een passende activiteit gekoppeld, waarbij een tijd- en kostennorm is gekozen. $\mathrm{Er}$ is daarbij een inschatting gemaakt van de factoren die daarvoor van belang zijn, bijvoorbeeld voor het aantal te snoeien takken of omstandigheden om te maaien. De resultaten zijn daarom een redelijke benadering van de kosten.

Een kanttekening is dat het beheer mede gericht is op de mogelijkheid van het winnen van zaad en stekmateriaal. Hierdoor hebben sommige soorten wellicht een kortere omloop dan ze zouden hebben wanneer ze vrij uitgroeien, gericht op het slechts in stand houden van de accessies. Daarbij zal ook de ruimte die ze innemen soms kleiner zijn dan bij vrije groei.

Vergelijking van de uitkomsten met realisatiecijfers (nacalculatie) is niet goed mogelijk, omdat recentelijk veel met mensen met afstand tot de arbeidsmarkt (sociaal werk) wordt gewerkt. Deze realiseren normaal gesproken een beperkt deel van de productiviteit van reguliere medewerkers waar tijdnormen op zijn gestoeld. In vergelijking van kosten voor beheer van gemeentelijk groen, waarvan goede kengetallen beschikbaar zijn, lijken de uitkomsten redelijk vergelijkbaar. Het daadwerkelijk vastleggen van werkzaamheden (tijdregistratie en frequenties) zou echter de werkelijke kosten goed in beeld kunnen brengen.

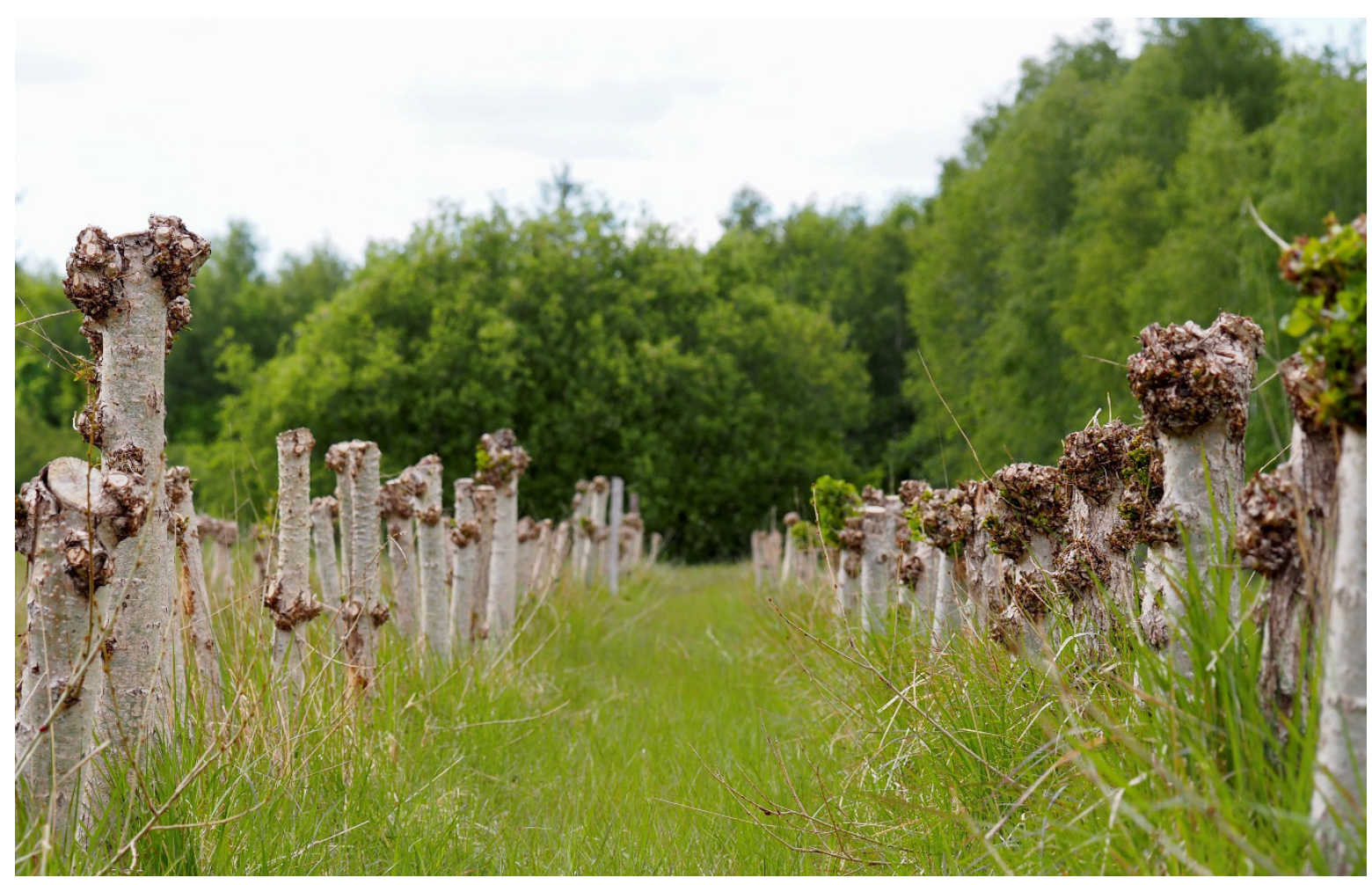

Figuur 3.3 Moerstoven van Populus nigra in de genenbank. Moerstoven worden periodiek 'geknot' om stekmateriaal te oogsten en nemen minder plek in beslag dan collecties die als zaadgaard dienen.

6 Grofweg na eerste proeven hiermee $€ 1.000$ per ha $* 2$ à 3 werkgangen per jaar. Navenant het resultaat toeneemt kan worden overgeschakeld naar mechanische bestrijding met boomgaardschijf of cultivator. Kosten dalen dan naar circa $€ 120$ per ha $* 3$ werkgangen per jaar (kan fluctueren - natte/droge zomers). 


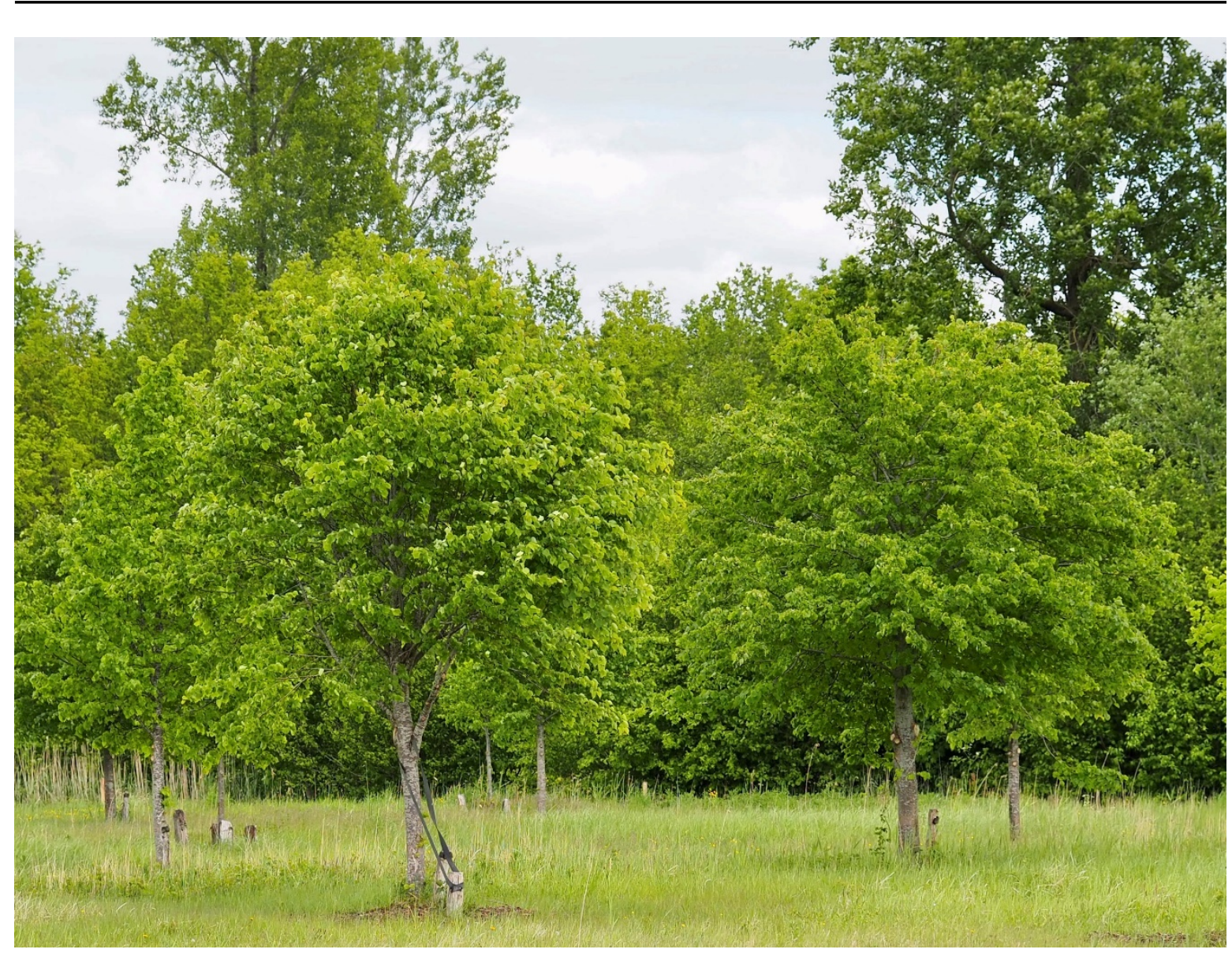

Figuur 3.4 Bomen groot, Ulmus laevis collectie in de genenbank.

Tabel 3.3 Overzicht van uitgangspunten voor de berekening van de kosten.

\begin{tabular}{|c|c|c|c|c|c|}
\hline onderwerp & $\begin{array}{l}\text { bomen } \\
\text { klein }\end{array}$ & $\begin{array}{l}\text { bomen } \\
\text { groot }\end{array}$ & $\begin{array}{l}\text { struiken } \\
\text { klein }\end{array}$ & $\begin{array}{l}\text { struiken } \\
\text { groot }\end{array}$ & moerstoof \\
\hline typische soorten & $\begin{array}{l}\text { bv. lijsterbes, peer, } \\
\text { taxus }\end{array}$ & $\begin{array}{l}\text { bv. linde } \\
\text { haagbeuk }\end{array}$ & bv. zwarte bes & $\begin{array}{l}\text { bv. hazelaar } \\
\text { meidoorn }\end{array}$ & populier, wilg \\
\hline aanleg & $\begin{array}{l}\text { woelen, planten, } \\
\text { boompalen, } \\
\text { startbemesting } \\
\text { geven, } \\
\text { plantspiegels leggen }\end{array}$ & $\begin{array}{l}\text { woelen, planten, } \\
\text { boompalen, } \\
\text { startbemesting } \\
\text { geven, } \\
\text { plantspiegels leggen }\end{array}$ & $\begin{array}{l}\text { frezen, planten, } \\
\text { startbemesting } \\
\text { geven, } \\
\text { plantstroken zwart } \\
\text { houden }\end{array}$ & $\begin{array}{l}\text { frezen, planten, } \\
\text { startbemesting } \\
\text { geven, } \\
\text { plantstroken zwart } \\
\text { houden }\end{array}$ & $\begin{array}{l}\text { frezen, woelen, } \\
\text { planten, } \\
\text { startbemesting } \\
\text { geven } \\
\text { plantstroken zwart } \\
\text { houden }\end{array}$ \\
\hline plantmateriaal & 5 euro/stu & 5 euro, & 5 eurc & 5 eurc & 0,5 euro/stuk, stek \\
\hline inboeten & $10 \%$ & $10 \%$ & $10 \%$ & $10 \%$ & $10 \%$ \\
\hline onkruidbestrijding & $\begin{array}{l}4 \times \text { per jaar in de } \\
\text { eerste } 6 \text { jaar } \\
\text { mechanisch } \\
\text { (schoffel) }\end{array}$ & $\begin{array}{l}\text { 4x per jaar in de } \\
\text { eerste } 6 \text { jaar } \\
\text { mechanisch } \\
\text { (schoffel) }\end{array}$ & $\begin{array}{l}4 x \text { per jaar } \\
\text { mechanisch } \\
\text { (schoffel) en } 2 x / j r \\
\text { extra in jaar } 1 \text { en } 2\end{array}$ & $\begin{array}{l}4 x \text { per jaar in de } \\
\text { eerste } 6 \text { jaar } \\
\text { mechanisch } \\
\text { (schoffel) en } 2 x / \text { jr } \\
\text { extra in jaar } 1 \text { en } 2\end{array}$ & $\begin{array}{l}4 x \text { per jaar in de } \\
\text { eerste } 6 \text { jaar } \\
\text { mechanisch } \\
\text { (schoffel) en } 2 x / j r \\
\text { extra in jaar } 1 \text { en } 2\end{array}$ \\
\hline beplanting & boomweide & boomweide & strook & strook & strook \\
\hline plantverband & $4 \times 4 \mathrm{~m}$ & $8 \times 8 \mathrm{~m}$ & $1,5 \times 4 \mathrm{~m}$ & $3 \times 5$ meter & $1 \times 1,5$ meter \\
\hline $\begin{array}{l}\text { maaien strook } \\
\text { tussen beplanting }\end{array}$ & $\begin{array}{l}\text { gehele opp. met } \\
\text { trekker met } \\
\text { klepelmaaier }\end{array}$ & $\begin{array}{l}\text { gehele opp. met } \\
\text { trekker met } \\
\text { klepelmaaier }\end{array}$ & $\begin{array}{l}\text { ruwterreinmaaier, } \\
1 \mathrm{~m} \text { brede strook }\end{array}$ & $\begin{array}{l}\text { gehele opp. met } \\
\text { ruwterreinmaaier }\end{array}$ & $\begin{array}{l}\text { ruwterreinmaaier, } \\
1 \mathrm{~m} \text { brede strook }\end{array}$ \\
\hline frequentie & $4 x / j r$ & $4 x / j r$ & $8 x / j r$ & $8 \times / j r$ & $8 x / j r$ \\
\hline $\begin{array}{l}\text { maaien in } \\
\text { beplanting }\end{array}$ & $\begin{array}{l}\text { bosmaaien rond } \\
\text { bomen }\end{array}$ & $\begin{array}{l}\text { bosmaaien rond } \\
\text { bomen }\end{array}$ & bosmaaien in strook & $\begin{array}{l}\text { bosmaaien rond } \\
\text { struiken }\end{array}$ & bosme \\
\hline
\end{tabular}




\begin{tabular}{|c|c|c|c|c|c|}
\hline \multirow[t]{2}{*}{ onderwerp } & bomen & bomen & struiken & struiken & moerstoof \\
\hline & klein & groot & klein & groot & \\
\hline frequentie & $2 / j \mathrm{jr}$ & $2 / \mathrm{jr}$ & $4 \mathrm{x} / \mathrm{jr}$ & $4 \mathrm{x} / \mathrm{jr}$ & $4 \mathrm{x} / \mathrm{jr}$ \\
\hline snoei & begeleidingssnoei & begeleidingssnoei & $\begin{array}{l}\text { afzetten of snoeien } \\
(50 / 50)\end{array}$ & $\begin{array}{l}\text { afzetten of snoeien } \\
(50 / 50)\end{array}$ & $\begin{array}{l}\text { alles op stoof } \\
\text { terugzetten } \\
\text { (jaarlijks) }\end{array}$ \\
\hline frequentie & $\begin{array}{l}\text { Eerste } 10 \text { jaar om } \\
\text { het jaar, daarna per } \\
4 \text { jaar }\end{array}$ & $\begin{array}{l}\text { Eerste } 10 \text { jaar om } \\
\text { het jaar, daarna per } \\
4 \text { jaar }\end{array}$ & $\begin{array}{l}50 \% \text { jaarlijks } \\
\text { vormsnoei, } 50 \% \text { per } \\
4 \text { jr afzetten }\end{array}$ & $\begin{array}{l}50 \% \text { jaarlijks } \\
\text { vormsnoei, } 50 \% \text { per } \\
10 \mathrm{jr} \text { afzetten }\end{array}$ & jaarlijks \\
\hline bemesten & $\begin{array}{l}20 \mathrm{~kg} \text { compost per } \\
\text { boom }\end{array}$ & $\begin{array}{l}20 \mathrm{~kg} \text { compost per } \\
\text { boom }\end{array}$ & $\begin{array}{l}10 \mathrm{~kg} \text { compost per } \\
\text { boom }\end{array}$ & $\begin{array}{l}20 \mathrm{~kg} \text { compost per } \\
\text { boom }\end{array}$ & $\begin{array}{l}10 \mathrm{~kg} \text { compost per } \\
\text { boom }\end{array}$ \\
\hline frequentie & per 4 jaar & per 4 jaar & per 4 jaar & per 4 jaar & per 4 jaar \\
\hline verwijderen & vellen, stobbefrezen & vellen, stobbefrezen & $\begin{array}{l}\text { rooien met kleine } \\
\text { graafmachine }\end{array}$ & $\begin{array}{l}\text { afzetten, stobbe } \\
\text { frezen }\end{array}$ & afzetten, frezen \\
\hline termijn & 20 jaar & 30 jaar & 15 jaar & 20 jaar & 15 jaar \\
\hline
\end{tabular}

Tabel 3.4 Kosten per stuk voor aanleg en onderhoud.

\begin{tabular}{|c|c|c|c|c|c|c|c|c|c|c|c|}
\hline & \multicolumn{2}{|c|}{$\begin{array}{l}\text { euro/keer } \\
\text { per exemplaar }\end{array}$} & \multicolumn{9}{|c|}{ euro/jr per exemplaar } \\
\hline & 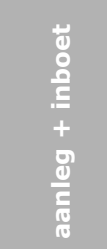 & $\frac{5}{3}$ &  & 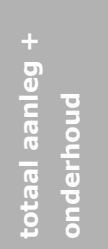 & $\frac{8}{\frac{8}{3}}$ &  & $\begin{array}{l}\text { 월 } \\
\text { पू } \\
\text { हू } \\
0\end{array}$ & 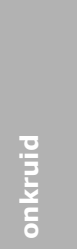 & 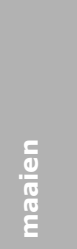 & $\frac{5}{\frac{5}{0}}$ & $\frac{5}{\frac{5}{5}}$ \\
\hline boom klein & 54,63 & 31,67 & 6,25 & 10,57 & 2,60 & 0,13 & 1,35 & 1,38 & 1,73 & 1,79 & 1,58 \\
\hline boom groot & 53,95 & 37,70 & 9,35 & 12,40 & 1,74 & 0,06 & 1,35 & 1,12 & 4,79 & 2,09 & 1,26 \\
\hline struik klein & 16,17 & 3,73 & 3,63 & 4,95 & 0,99 & 0,08 & 0,68 & 1,13 & 0,11 & 1,71 & 0,25 \\
\hline struik groot & 16,76 & 10,93 & 8,67 & 10,05 & 0,78 & 0,06 & 1,35 & 2,97 & 1,58 & 2,76 & 0,55 \\
\hline moerstoof & 12,46 & 0,60 & 1,83 & 2,70 & 0,78 & 0,05 & 0,68 & 0,49 & 0,11 & 0,56 & 0,04 \\
\hline
\end{tabular}

\subsection{Kosten per scenario}

$\mathrm{Er}$ is gerekend met twee scenario's, met elk twee varianten:

Scenario 1A: Huidige aantal accessies en individuen in stand houden.

Scenario 1B: Huidige accessies en soorten in stand houden, met benodigd aantal individuen voor genenbewaring en zaadoogst ( $n=5$ met uitzondering van de categorie struiken klein en moerstoven waar $n=10)$.

Scenario 2A: Optimale situatie: gewenste aantal accessies en soorten, met benodigd aantal individuen voor genenbewaring en zaadoogst $(n=5$ met uitzondering van de categorie struiken klein en moerstoven waar $n=10$ ).

Scenario 2B: Als scenario 2A, maar dan worden collecties van sommige soorten niet in Roggebotzand aangehouden, maar vindt genenbewaring op alternatieve wijze plaats (bijv. op een kwekerij, zaadbank of ex-situpopulaties elders).

In de kostenberekening is uitgegaan van het volgende:

- In de kostenberekening voor de verschillende varianten wordt een onderscheid gemaakt tussen prioritaire soorten en complementaire soorten. Bij deze laatste dienen de collecties primair voor zaadproductie. 
- Een schatting van het aantal benodigde individuen. De genoemde aantallen zijn voldoende voor genenbewaring en zaadoogst. Wanneer in de berekening van de totale aantallen individuen per collectie (aantal accessies $x$ aantal kopieën per accessies) rekening wordt gehouden met een toename in zaadproductie, dan vergt dit een extra rekenslag. De behoefte aan zaad is groeiende i.v.m. meer aanleg bos en beplantingen in de komende jaren. ${ }^{7}$ Voor zaadproductiecapaciteit is hier een doorrekening nodig op basis van prognose van zaadbehoefte op middellange termijn en de gemiddelde zaaddracht per boom/struik/per jaar. Dit valt buiten dit implementatieplan.

- De kosten zijn per exemplaar berekend en vermenigvuldigd met het aantal exemplaren.

- Scenario 1A wordt beschouwd als de 'baseline', maar komt niet overeen met het huidige beheer. Het geeft eerder aan hoe het beheer van de huidige collectie zou moeten worden uitgevoerd. Dit betekent dat alle vier scenario's die geschetst worden, afwijken qua kosten van het huidige beheer.

De verandering van het huidige beheer naar een ander scenario zal tijd vergen. Vanuit het huidige beheer naar scenario $1 \mathrm{~A}$ vergt op onderdelen een andere aanpak van beheer. Vooral de andere aanpak van onkruidbestrijding bij kleine struiken zal wellicht geleidelijk moeten gaan om te schakelen van uitmaaien naar schoffelen van onkruid.

Voor de overige scenario's geldt dat de aanpassingen in de aantallen exemplaren geleidelijk over de jaren uitgespreid zal worden. Zo zullen de kosten van die scenario's zich in de loop van de jaren richting de berekende kosten kunnen bewegen wanneer geleidelijk wordt omgevormd en tijdens de reguliere verjonging van accessies. Dit kan bijvoorbeeld tien jaar in beslag nemen. Berekende kosten voor nieuwe aanplant in die scenario's zal ook over meerdere jaren uitgespreid worden. Voor een deel zal dit in het reguliere beheer kunnen worden uitgevoerd, aangezien er van sommige accessieexemplaren te veel zijn, die kunnen worden vervangen door exemplaren van accessies die uitgebreid dienen te worden.

\subsubsection{Kosten scenario 1 Minimaal}

De kosten voor jaarlijks beheer van de huidige collectie (scenario $1 \mathrm{~A}$ ) bedragen $€ 99.085$ per jaar voor prioritaire soorten) en $€ 187.467$ voor de totale collectie. De kosten voor regulier onderhoud bedragen daarvan $€ 146.807$ en de kosten voor periodiek vervangen van exemplaren $€ 40.660$.

Als wordt gerekend met het normatieve aantal exemplaren per accessie ( 5 ofwel 10, scenario 1B), dan liggen de kosten iets hoger en bedragen voor jaarlijks beheer $€ 127.824$ voor prioritaire soorten.

\subsubsection{Kosten scenario 2 Optimaal}

De kosten bij scenario 2A bedragen $€ 169.042$ (alleen de prioritaire soorten). Daarvan is $€ 128.945$ voor regulier onderhoud en $€ 40.097$ voor periodieke vervanging. De jaarlijkse kosten voor beheer bedragen bij scenario $2 B € 140.339$ (alleen de prioritaire soorten), waarvan $€ 107.624$ regulier onderhoud en $€ 32.715$ voor periodieke vervanging. De kosten voor alternatieven moeten hierbij worden opgeteld (bijv. zaadcollecties, kwekerijcollecties). Kosten voor aanhouden van kwekerijcollecties zijn nog niet goed bekend. Schatting van kosten voor zaadcollecties worden in hoofdstuk 4 gegeven en worden geschat op $€ 30300$ per jaar voor deze 12 soorten over een periode van 10 jaar. Totale kosten scenario $2 \mathrm{~B}$ zijn $€ 170639$.

\subsubsection{Optimalisatie van het aantal planten per accessie}

De scenario's 1B, 2A en 2B met $n=5$ of $n=10$ hebben als consequentie dat extra individuen aangeplant moeten worden (indien $n$ te laag) of op termijn verwijderd kunnen worden (te veel kopieën verwijderen). Bij voorkeur vindt dit plaats tijdens de periodieke vervanging/verjonging van bomen,

\footnotetext{
7 Bosuitbreiding en revitalisering de komende tien jaar wordt geschat op: 5.000 ha nieuw bos, 4.500 ha essenbos revitaliseren, 4.000 ha fijnspar en lariks bos omvormen/revitaliseren, sponsorbossen 25 ha/jaar, reguliere kap en verjonging 10 ha per jaar bij SBB, met landelijke partners en partijen 37.000 ha bos waarvan 5.000 nieuw bos bij SBB, nieuwe initiatieven (zie plannen Overijsel/Gelderland). De schatting is per ha nieuw bos 5.000 bomen/struiken waarvan ca. $10-15 \%$ struiken, voor revitalisering 4.000 bomen/struiken waarvan $10 \%$ struiken.
} 
struiken of moerstoven of bij overplaatsing van collecties. Hoeveel exemplaren er precies aangeplant of verwijderd moeten worden, verschilt per accessie. In deze berekening is hier geen rekening mee gehouden en is per soort met netto-aantallen gerekend. Het kan dus zijn dat er binnen een soort evenveel exemplaren van bepaalde accessies bij geplant moeten worden als dat er van andere accessies verwijderd moeten worden, wat netto niet leidt tot een ander aantal.

Het aantal exemplaren neemt bij scenario 1B met 3.477 exemplaren van prioritaire soorten toe. Uitgaande van aanplant van deze exemplaren bedragen de kosten voor aanplant naar schatting $€ 115.145$.

De kosten voor nieuwe aanplant bedragen bij scenario $2 \mathrm{~A} € 244.722$. Dit is meer dan bij scenario $1 \mathrm{~B}$, ervan uitgaande dat voor alle reeds aanwezige soorten en nieuw op te nemen soorten het beoogde aantal exemplaren per accessie wordt geoptimaliseerd.

Bij scenario 2B, wanneer een deel van de soorten niet in de genenbank (veldcollectie) wordt opgenomen maar via alternatieve methoden wordt geborgd, bedragen de kosten voor uitbreiding van de genenbank $€ 164.242$.

De kosten zullen hoger worden als de ruimtelijke rangschikking het nodig maakt dat volledige soorten en accessies verplaatst (nieuw opgezet) moeten worden, om ze vanuit praktische overwegingen bij elkaar te houden. We gaan er echter van uit dat een belangrijk deel van deze kosten binnen de reguliere beheercyclus uitgevoerd kunnen worden (periodieke vervangingen aan het eind van de cyclus van een accessie), zodat deze investeringen niet geheel direct genomen hoeven te worden.

Tabel 3.5 Overzicht van aantal exemplaren, oppervlak en kosten voor onderhoud, vervanging en maaibeheer (klepelen op additioneel areaal van 25\%), voor alle soorten van scenario $1 A$.

\begin{tabular}{|c|c|c|c|c|c|c|c|c|}
\hline Scenario & Categorie & $\begin{array}{l}\text { Aantal } \\
\text { exemplaren }\end{array}$ & Opp. $\left(m^{2}\right)$ & $\begin{array}{l}\text { Onderhoud } \\
\text { en vv } \\
\text { (euro/jr) }\end{array}$ & $\begin{array}{l}\text { wv } \\
\text { onderh. } \\
\text { (euro/jr) }\end{array}$ & $\begin{array}{l}\text { wv } \\
\text { periodiek } \\
\text { vervangen } \\
\text { (euro/jr) }\end{array}$ & $\begin{array}{l}\text { Arbeids- Nieuwe } \\
\text { behoefte aanplant } \\
\text { (uur/jr) }\end{array}$ & $\begin{array}{l}\text { Klepelen } \\
\text { thosten } \\
\text { (euro/jr) }\end{array}$ \\
\hline \multicolumn{9}{|l|}{$1 \mathrm{~A}$} \\
\hline & prioritair & 14.008 & 176.447 & 99.085 & 75.914 & 23.171 & 1.636 & 3.397 \\
\hline & complementair & 10.351 & 155.908 & 84.991 & 68.694 & 16.297 & 1.493 & 3.001 \\
\hline & overig & 937 & 2.986 & 3.390 & 2.199 & 1.191 & 47 & 57 \\
\hline & TOTAAL & 25.296 & 335.341 & 187.467 & 146.807 & 40.660 & 3.176 & 6.455 \\
\hline
\end{tabular}

Tabel 3.6 Overzicht van aantal exemplaren, oppervlak en kosten voor onderhoud, vervanging en maaibeheer (klepelen op additioneel areaal van 25\%) voor de prioritaire soorten van alle scenario's.

\begin{tabular}{|c|c|c|c|c|c|c|c|c|c|}
\hline Scenario & Categorie & $\begin{array}{l}\text { Aantal } \\
\text { exemplaren }\end{array}$ & Opp. $\left(\mathrm{m}^{2}\right)$ & $\begin{array}{l}\text { Onderhoud } \\
\text { en vv } \\
\text { (euro/jr) }\end{array}$ & $\begin{array}{l}\text { wv } \\
\text { onderh. } \\
\text { (euro/jr) }\end{array}$ & $\begin{array}{l}\text { wv } \\
\text { periodiek } \\
\text { vervangen } \\
\text { (euro/jr) }\end{array}$ & $\begin{array}{l}\text { Arbeids- } \\
\text { behoefte } \\
\text { (uur/jr) }\end{array}$ & $\begin{array}{l}\text { Nieuwe } \\
\text { aanplant }\end{array}$ & $\begin{array}{l}\text { Klepelen } \\
\text { kosten } \\
\text { (euro/jr) }\end{array}$ \\
\hline $1 \mathrm{~A}$ & prioritair & 14.008 & 176.447 & 99.085 & 75.914 & 23.171 & 1.636 & - & 3.397 \\
\hline $2 \mathrm{~A}$ & prioritair & 23.955 & 295.865 & 169.042 & 128.945 & 40.097 & 2.785 & 244.722 & 4.750 \\
\hline $2 B$ & prioritair & 18.990 & 258.510 & 140.339 & 107.624 & 32.715 & 2.318 & 164.242 & 4.624 \\
\hline
\end{tabular}




\subsection{Aanvullende kosten}

Enkele kosten zijn in bovenstaande berekeningen niet meegenomen. Het gaat om enkele specifieke kosten. Deels gaat het om specifieke eenmalige kosten. Voor de eenmalige investeringen is door Staatsbosbeheer een inschatting gemaakt (zie hoofdstuk 1 Tabel 2.2 en begin van deze paragraaf). Daarbij dient aangetekend te worden dat sommige investeringen, m.n. het raster, ook zullen leiden tot extra regulier onderhoud en vervanging op termijn. De kosten hiervan zijn niet in de berekening opgenomen. Daarnaast zijn er aanvullende kosten voor algemeen terreinonderhoud. De kosten voor het klepelen van het terrein zijn zeer beperkt vergeleken met de kosten voor het onderhoud van de accessies en bedragen $€ 3.397$ (1B) tot $€ 4.750$ (2A) per jaar (zie Tabel 3.6). Er dient naar schatting ca. $8500 \mathrm{~m}$ schouwsloot geschoond te worden. De kosten hiervan bedragen $€ 4.233$ per jaar.

Overige niet meegenomen kosten in deze berekeningen zijn:

- periodiek water geven (wel basis water geven na aanplant), waarvan de huidige kosten $€ 35.000$ per jaar zijn en na verbetering van de inrichting geschat worden op $€ 10.000$ per jaar. Periodiek water geven moet geregeld zijn in een goed waterbeheerplan (zie ook herstelmaatregelen), bijvoorbeeld in combinatie met druppelirrigatie. Het enige dat overblijft is dat tijdens het groeiseizoen water wordt door- of overgepompt vanuit de Roggebottocht in de aanvoersloten van genenbank West;

- bestrijding ziekten en plagen, facultatief, maar rekening houden met $€ 5.000$ per jaar;

- bestrijding van specifieke (on)kruiden, zoals duinriet en braam, overige houtige opslag. Dit is nu nog een zeer grote kostenpost, maar kan geoptimaliseerd worden (mechanisch en goede inrichting plantbedden);

- oogst;

- projectbegeleiding vanuit Staatsbosbeheer (schatting 15\% van totale kosten);

- wetenschappelijke ondersteuning voor opbouw, optimalisatie en informatievoorziening over de collecties door CGN vanuit WOT-programma Genetische Bronnen. 


\section{$4 \quad$ Opbouw van back-upcollecties}

\subsection{Achtergrond}

De genenbankcollecties worden momenteel op één locatie in stand gehouden, op enkele uitzonderingen na. Conservering in het veld, in combinatie met het grotendeels ontbreken van veiligheidsduplicatie, biedt geen goede garantie voor behoud op lange termijn van het genetisch materiaal. Levende bomen en struiken zijn kwetsbaar voor biotische en abiotische stress, bijvoorbeeld weersomstandigheden, plagen en ziekten, storm, brand et cetera. Ook vereist een levende collectie veel onderhoud. In de huidige situatie is het gevaar van verlies van materiaal door ziekten, plagen of calamiteiten dan ook reëel. Het is daarom wenselijk voor de Roggebotzand-collectie een veiligheidsduplicaat aan te leggen op een andere locatie of een back-up in de vorm van een alternatieve conserveringsmethode.

De opbouw van back-up-/duplicaatcollecties moet dienen als een garantie tegen verlies van materiaal in de genenbank en in-situpopulaties van de zeldzaamste en meest bedreigde bomen en struiken. In voorkomende gevallen kan dit back-upmateriaal het herstel en herintroductie van deze populaties mogelijk maken. Het streven is om op de middellange termijn (de komende tien jaar) genetisch representatieve back-up-/duplicaatcollecties van ten minste 50\% (afhankelijk van kosten) van de zeldzaamste, meest bedreigde inheemse boom- en struiksoorten te hebben verzameld en bewaard.

In dit hoofdstuk worden methoden en activiteiten beschreven die nodig zijn om deze back-upstrategieën voor de betreffende soorten te realiseren, inclusief onderzoek dat nodig is om de kennis te verbeteren over zaadbiologie (kieming van boomzaden). Daarnaast worden de kosten op een rijtje gezet voor implementatie en een tijdsplanning voor tien jaar gegeven. Bij het opstellen van dit backupplan zijn diverse genenbankorganisaties in Europa gecontacteerd over de mogelijkheden voor opbouw van duplicaatcollecties en zaadbanken. Daarnaast zijn collega's van het CGN-cluster dier en cluster CGN-plant geconsulteerd over cryo-conservering en zaadopslag. Tot slot is een beknopte literatuurresearch gedaan naar de stand van zaken over zaadopslag bij bomen.

\subsection{Methoden}

Voor het aanleggen van duplicaat- en back-upcollecties bestaan verschillende mogelijkheden:

$>$ Veldcollecties op een andere locatie. Voor enkele soorten (UImus laevis, Tilia cordata) zijn al (deels) accessies gedupliceerd op een andere locatie. Risico's op verlies van materiaal door ziekte, slechte groeiomstandigheden, calamiteiten zijn hier hetzelfde als in Roggebotzand. Daarbij is het logistiek onhandig om op meerdere locaties verspreid door Nederland duplicaatcollecties in stand te houden en zijn de kosten qua beheer en onderhoud van deze duplicaatcollecties vergelijkbaar met Roggebotzand.

$>$ In-vitrocollecties. Back-up in de vorm van in-vitrocollecties van cultures (scheuttopjes, meristemen, somatische embryo's) is niet geschikt voor langetermijnbewaring, heeft een verhoogd risico op somaklonale variatie en is relatief duur, omdat het hoge eisen stelt aan labfaciliteiten.

> Conventionele zaadbank. Langdurige opslag van zaden (bijv. generatieduur van de boom) is mogelijk voor veel boom- en struiksoorten in een conventionele zaadbank (drogen tot ca. $10-15 \%,-20^{\circ} \mathrm{C}$ ). Voor sommige boom- en struiksoorten, die slecht tegen uitdroging kunnen of een zeer korte levensduur hebben of beide, is een conventionele zaadbank geen optie.

$>$ Cryo-conservering. Cryo-conservering is de opslag van biologisch materiaal (zaden, embryo's, scheutpunten, winterknoppen) bij ultra lage temperaturen, meestal die van vloeibare stikstof (LN) bij $-196^{\circ} \mathrm{C}$. Onder cryogene omstandigheden worden de biochemische en meeste fysische processen stopgezet en kan materiaal voor zeer lange termijn worden bewaard. Cryo- 
conserveringstechnieken hebben zich sterk ontwikkeld de laatste twee decennia, waardoor ze een aantrekkelijke vorm van safety back-up voor klonale veldcollecties zijn geworden. Routinematige opslag in vloeibare stikstof als back-up wordt elders al toegepast voor enkele boom- en struiksoorten, waarbij voornamelijk gebruik wordt gemaakt van slapende knoppen (winterknoppen). Voorbeelden hiervan zijn collecties aangelegd van Corylus, Prunus, Pyrus, Ribes en Salix door de US Department of Agriculture-Agricultural Research Service (USDA-ARS) (Fort Collins). Gebrek aan soortspecifieke protocollen, het beperkte tijdvenster van diepe kiemrust waarin takken geknipt moeten worden, maar ook goede protocollen om de levensvatbaarheid na cryopreservatie te bepalen ter vervanging van enten, beperken de mogelijkheden om deze techniek routinematig uit te voeren bij veel soorten (Jenderek and Reed, 2017).

Cryogene opslag van zaden kan een alternatief zijn voor conventionele opslag bij $-20^{\circ} \mathrm{C}$. Voor sommige soorten is de levensduur van de zaden bij $-20^{\circ} \mathrm{C}$ kort en kan deze verlengd worden door opslag in de dampfase van vloeibare stikstof. Voorbeelden van boomzaden of fragmenten van zaden die in de stikstof worden bewaard door de Kostrzyca Forest Gene Bank in Polen zijn haagbeuk, peperboompje, berk, iep, eik, wilde appel, taxus en es. Met name als recalcitrante zaden te groot zijn om snel te drogen of af te koelen (bijvoorbeeld, eik, beuk, kastanje) worden veelal embryo's of embryonale assen gebruikt. Cryo-opslag van boomzaden zit nog steeds in de experimentele fase en vereist op maat gemaakte protocollen per soort. Vergeleken met conventionele zaadopslag zijn de kosten van cryo-opslag hoger. Dit wordt bepaald door de opslagkosten zelf (grote volumes door relatief grote zaden bij bomen), benodigde lab-faciliteiten (weefselkweek fase nodig om weer uit de cryo-opslag te halen, behalve bij kleine zaden), kosten van specifieke expertise en arbeid (prepareren materiaal voorafgaand aan opslag, bijv. uitprepareren embryo's).

Voor langetermijnconservering is een zaadbank over het algemeen de kosteneffectiefste methode, daarna cryo-opslag van embryo's, weefselopslag en als laatste een veld genenbank/levende collecties (Pence, 2011). De kosten voor een veldcollectie van bijvoorbeeld Ulmus klonen is twee keer de kosten van cryo-opslag van deze accessies via winterknoppen (Li and Pritchard, 2009).

Rekening houdend met eisen als 1) geschikt voor zeer langetermijnbewaring, 2) bij voorkeur niet buiten en 3) kostenefficiënt, komen voor het opzetten van back-upcollecties conventionele zaadopslag $\left(-20^{\circ} \mathrm{C}\right)$ en cryo-conservering als methode in aanmerking. Aangeraden wordt om beide methoden te implementeren, maar in principe conventionele opslag toe te passen en cryoconservering te gebruiken bij soorten waar conventionele zaadopslag geen optie is (recalcitrante zaden, geen of te weinig zaadproductie, slechts enkele genotypen nog aanwezig). 


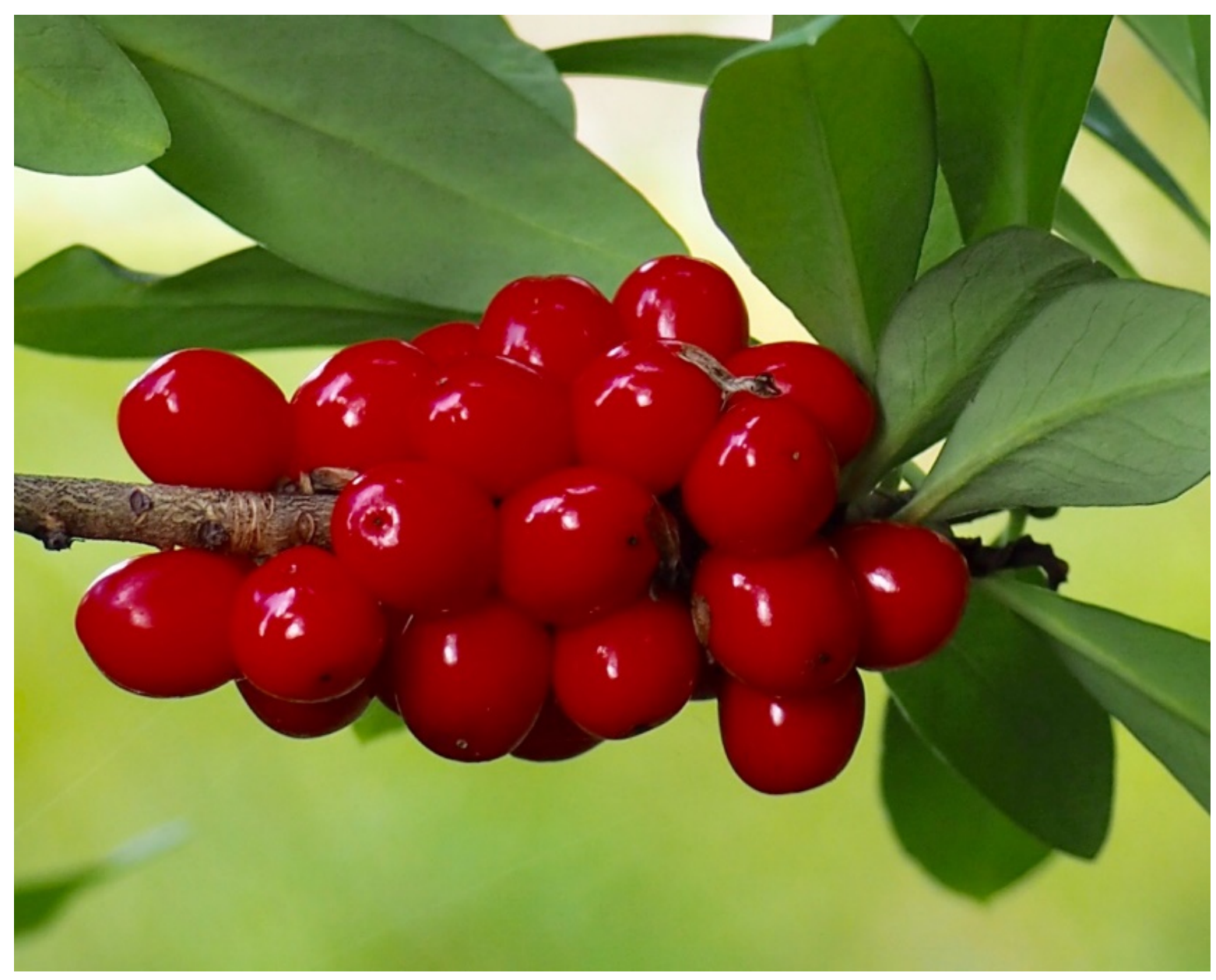

Figuur 4.1 Daphne mezereum. Het peperboompje staat op de Nederlandse Rode Lijst van planten als zeer zeldzaam en matig in aantal afgenomen. De genenbank is qua groeiplaats niet geschikt voor deze soort. De zaden van deze soort zijn orthodox en kunnen als alternatief bewaard worden in zaadcollecties.

\subsection{Zaadopslag-gedrag en kiemrust-karakteristieken}

Langdurige opslag van zaden (bijv. generatieduur van de boom) is mogelijk voor veel boom- en struiksoorten. De meeste soorten zijn gemakkelijk op te slaan, echter sommige boom- en struiksoorten zijn lastig, omdat ze slecht tegen uitdroging kunnen of een zeer korte levensduur hebben of beide. Zaden kunnen grofweg in drie categorieën worden ingedeeld wat betreft hun zaadopslag-gedrag: orthodox (uitdrogingstolerant), recalcitrant (overleven geen laag vochtgehalte) en intermediair (tolereren drogen tot ca. $10-15 \%$, maar kunnen niet bij lage temperatuur, $-20^{\circ} \mathrm{C}$, opgeslagen worden). Daarnaast verschillen zaden in kiemrust-karakteristieken, die bepalen of en welke voorbehandelingen en stratificatiemethoden toegepast moeten worden om zaden te laten kieming na langdurige opslag. Soorten zijn onder te verdelen in soorten die een ondiepe of diepe kiemrust kennen of hardschalig zijn (zie Tabel 4.1). 
Tabel 4.1 Overzicht van zaadopslag- en kiemrust-karakteristieken van inheemse boom- en struiksoorten (Bron Storage behaviour tool van Royal Botanical Gardens, Kew, Gosling, 2007).

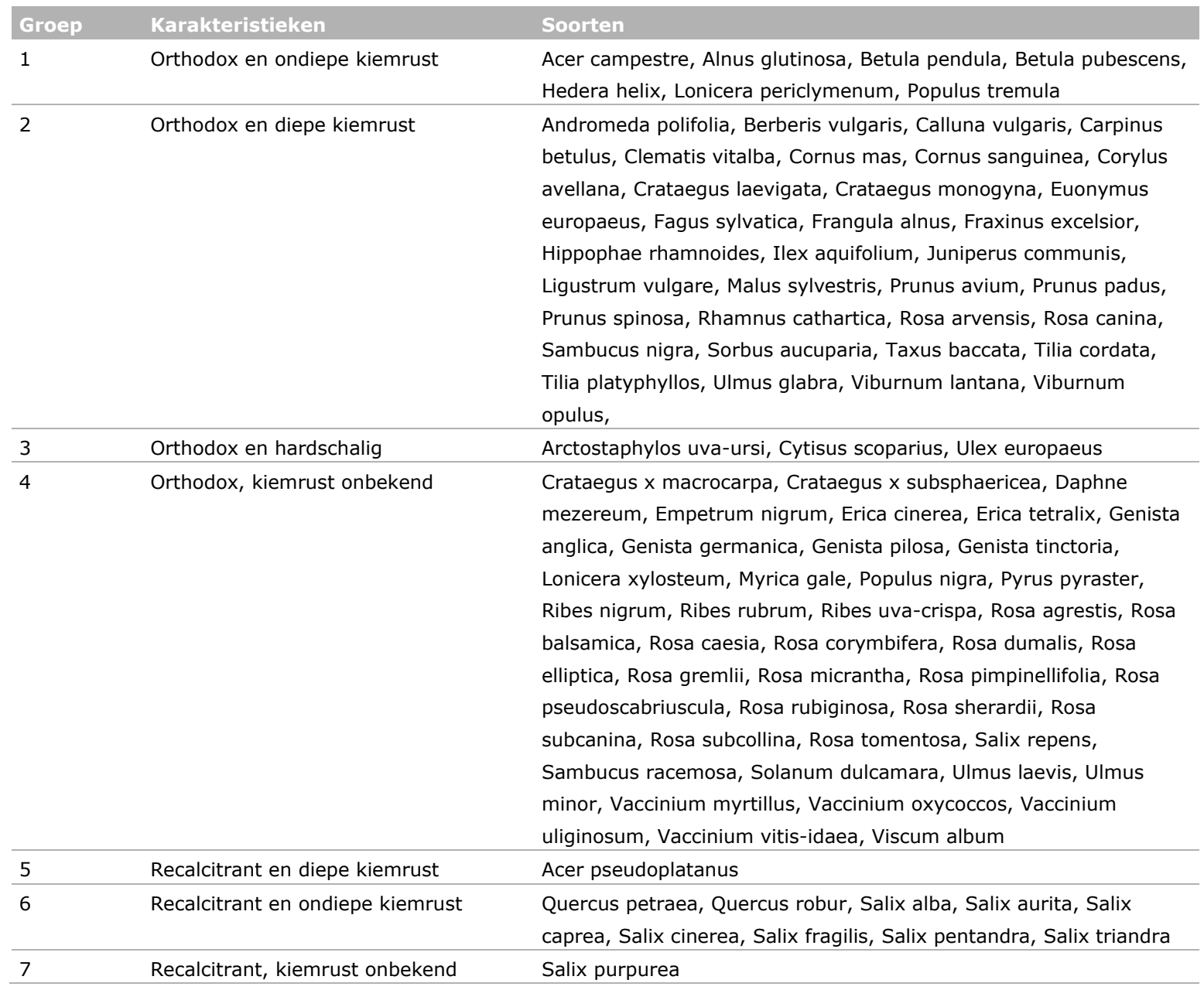

\subsection{Stappen in het opbouwen van back-upcollecties}

Factoren die de kosten bepalen van het opbouwen van back-upcollecties zijn de omvang van de collecties, het aantal soorten, maar ook faciliteiten, kennis opbouw en arbeid. Stappen in de procedure van zaadcollecties aanleggen bestaan uit:

$>$ Zaadverzameling en documentatie van de locaties (eventueel met herbarium materiaal). Verzameling van zaden op locatie volgens bestaande richtlijnen (bijv. ENSCONET (http://ensconet.maich.gr/PDF/Collecting_ protocol_English.pdf) in overleg met lokale organisaties. Voor veel boom- en struiksoorten zullen verzamelrichtlijnen moeten worden opgesteld.

$>$ Zaadverwerking en schoning. Voor een deel zal dit handmatig uitgevoerd moeten worden gezien de grote verschillen in zaadmorfologie bij boom- en struiksoorten.

$>$ Zaaddroging. Drogen van zaden in droogkamer tot vochtigheid van 3-6\% volgens standaarden en protocollen.

$>$ Kiemingbepaling en vitaliteitsmonitoring. Het testen van de levensvatbaarheid van de zaden d.m.v. kiemingkracht- en vitaliteitstoetsen onder gecontroleerde omstandigheden voordat de zaden worden opgeslagen. Hiervoor zullen ISTA-protocollen gevolgd worden, maar zullen ook soortspecifieke protocollen ontwikkeld worden. Uitvoeren van soortspecifieke behandelingen van het zaad om kiemrust op te heffen (stratificatie).

$>$ Uitdrogingstolerantietoetsen (specifiek voor cryo-opslag). Levensvatbaarheid van verschillende invriesmethoden toetsen.

$>$ Verpakken en bepalen hoeveelheid zaad.

$>$ Zaadbewaring. Afhankelijk van de soort bij $-20^{\circ} \mathrm{C}$ of vloeibare stikstof. 
$>$ Documentatie vastleggen in een accessie-database (velddata, kieming en zaadverwerking, herbarium etc.).

> Monitoring kiemkracht. Afhankelijk van de soort, methode en ervaringen bij andere genenbanken elke 5, 10 en 15 jaar.

\subsection{Kennisontwikkeling}

Daarnaast is er expertiseontwikkeling nodig om protocollen vast te stellen en is ondersteunend onderzoek nodig naar de zaadbiologie en kieming van specifieke soorten. Hieronder wordt een aantal onderzoekselementen genoemd om kennis op te bouwen.

$>$ Deskstudie: Het uitvoeren van een literatuursearch naar beschikbare kennis over langetermijnopslag bij bomen (zaadbiologie, levensduur in opslag, welke zaden recalcitrant zijn, invloed van factoren voor oogst, kortlevende vs. langlevende zaden, kiemingsbiologie en hoe kiemrust te doorbreken).

$>$ Ontwikkeling van verzamelstrategieën per soort/soortgroep. Een eerste stap in het opzetten van back-upcollecties is bepalen waar materiaal verzameld moet worden per soort. Hiervoor is het nodig inzicht te hebben in de verspreiding van de soorten en hun autochtone populaties en hun life history-karakteristieken. Bij voorkeur wordt gebruikgemaakt van informatie over de genetische diversiteit tussen en binnen populaties om de verzamelstrategie te ondersteunen en om richtlijnen op te stellen (het aantal populaties, aantal moederbomen per populaties, hoeveelheid zaad per boom etc.)

$>$ Ontwikkeling en verbetering van zaadopslag-protocollen bij soorten met orthodoxe zaden om de levensduur van zaad van deze soorten te verlengen. Zaadcollecties worden samengesteld volgens internationale genenbankstandaarden. Voor boomsoorten zijn deze niet van toepassing en zullen protocollen vastgesteld moeten worden op basis van literatuur en ervaring bij andere genenbanken.

$>$ Ontwikkeling van effectieve technieken voor het monitoren van de kiemkracht van de zaden, inclusief kiemrust-doorbreking. Voor boomsoorten zijn geen regeneratiestandaarden beschikbaar zoals bij gewassen.

> Ontwikkeling van soortspecifieke protocollen voor recalcitrante soorten. Goede protocollen voor screening en identificeren van werkelijk recalcitrante soorten zijn nodig om de efficiëntie van opslag te verbeteren. Dit kan bijvoorbeeld door te onderzoeken in welke mate uitdroging mogelijk is zonder kiemkracht te verliezen, het effect van cryogene temperatuur en zaadvochtigheid op kiemrust te bestuderen.

\subsection{Samenwerking}

Nagegaan is waar samenwerking mogelijk is voor het aanleggen van back-upcollecties en/of zaadbanken. Hieronder worden enkele mogelijke samenwerkingspartners genoemd:

$>$ Instituut voor Natuur- en Bosonderzoek (INBO, België): Vlaanderen heeft genenbanken annex zaadgaarden voor ca. 26 bedreigde inheemse soorten waarvan nauwelijks nog autochtone exemplaren voorkomen in Vlaanderen. Soorten waarvoor accessies uitgewisseld (aanleg safety duplicaten) of samengebracht kunnen worden, zijn zwarte populier, wilde appel, fladderiep en sommige rozen (Rosa tomentosa, Rosa agrestis). De noodzaak van het samenbrengen van collecties, omdat het om zeer kleine aantallen gaat, is het hoogst bij wilde peer en Viburnum lantana. Helaas zijn er geen betrouwbare autochtone genenbronnen van deze soorten meer in Vlaanderen (pers. mededeling K. van derMijnsbrugge).

> Royal Botanic Gardens Kew (UK): Kew heeft uitgebreide zaadcollecties aangelegd van de houtige wilde flora in de UK (zie ook UK National Tree Seed project). Er zijn mogelijkheden tot samenwerking met RBG Kew in het opzetten van collecties/training, opslag van safety duplicaten, onderzoek aan cryo-conservering.

$>$ ENSCONET; European Native Seed Conservation Network.

> Kostrzyca Forest Gene Bank (Polen); heeft lange ervaring met zowel conventionele opslag van boom en struiksoorten als cryo-conservering. 
> Levend archief (www.levendarchief.nl); heeft een groot netwerk aan partnerorganisaties, waarmee samengewerkt kan worden in bijv. verzamelen van zaden.

\subsection{Fasering}

De keuze tussen conventionele zaadopslag $\left(-20^{\circ} \mathrm{C}\right)$ en cryogene opslag wordt per soort gemaakt, omdat deze voornamelijk afhangt van hoe snel zaden hun levensvatbaarheid verliezen na opslag. Bij back-up van zeldzame genotypen zal de voorkeur uitgaan naar cryogene opslag van winterknoppen. In dit implementatieplan wordt in principe gekozen voor standaardopslag voor orthodoxe zaden en cryogene opslag bij recalcitrante zaden (Salix spp.). De gewenste methode per soort zal uiteindelijk pragmatisch benaderd worden en kan ook in een latere fase nog besloten worden. Voor backupcollecties bedoeld voor zeer langetermijnbewaring mogen kosten voor uit opslag halen (regeneratie ingeval van vervanging van materiaal in levende collectie/in vivo populaties) relatief hoger zijn, vergeleken met collecties die veelvuldig worden uitgegeven. De verhouding van kosten om materiaal in opslag te brengen t.o.v. eruit halen is dan ook een bepalende factor. Cryogene opslag kan hierdoor ook bij (kleine) orthodoxe zaden aantrekkelijk worden.

Voor bepaalde soorten is het sneller gewenst een back-upcollectie te realiseren dan voor andere, omdat de risico's op verlies groter zijn. Deze risicoafweging, maar ook praktische en financiële redenen bepalen dat er een fasering nodig is in het aanleggen van back-upcollecties. In eerste instantie gaat het om de prioritaire soorten, waarvoor een back-up aangelegd moet worden die in Roggebotzand staat of waarvoor een alternatief voor Roggebotzand gezocht moet worden. Om een prioritering te kunnen aanbrengen in soorten voor het gefaseerd aanleggen van deze back-ups, wordt rekening gehouden met de volgende criteria:

$>$ opname in Roggebotzand niet mogelijk (bijvoorbeeld door ziekte of standplaatsongeschiktheid);

$>$ collecties in Roggebotzand zijn moeizaam in leven te houden, waardoor de kans op uitval/verlies van materiaal groot is;

$>$ 'makkelijke' soorten met orthodoxe zaden (zie Tabel 4.1). Voor soorten met recalcitrante zaden is meer kennisontwikkeling nodig. Voor deze soorten zullen in een latere fase collecties aangelegd worden;

$>$ er is geen duplicaatcollectie aanwezig op een andere locatie of mogelijkheid tot het aanleggen van duplicaten in buurlanden;

$>$ zaadoogst moet mogelijk zijn. Soorten die weinig of geen zaden produceren of waarvan nog maar zeer weinig exemplaren aanwezig zijn om zaad van te oogsten (Viburnum lantana, Pyrus pyraster) zullen eerst in de levende collectie op Roggebotzand worden opgenomen alvorens duplicaatcollecties worden aangelegd;

$>$ ervaring met zaadbewaring van de soort bij zaadbanken in Europa.

De fasering in de tijd voor het aanleggen van back-upcollecties wordt weergegeven in Bijlage 4.

Wanneer rekening wordt gehouden met bovenstaande criteria, worden in een tijdsbestek van tien jaar back-upzaadcollecties aangelegd van 42 soorten.

\subsection{Benodigde faciliteiten voor back-upcollecties}

Zaadopslag (standaard of cryo) vereist een infrastructuur voor zaadverwerking, schoning, droging, opslag en monitoring. Hieronder worden de belangrijkste materialen en faciliteiten genoemd die nodig zijn voor zaadopslag:

> Droogkamer en/of incubator/droogkast/oven met vochtafzuiging voor zaadverwerking en droging, hygrometer, seed counter;

> Lab/ruimte voor zaadkieming en vitaliteitsmonitoring, koelkast, incubator met licht en temperatuur instelling, microscoop, consumables;

$>$ Zaadverwerkingsruimte met zeven, zuigers (kaft en lege zaden verwijderen), stofafzuiging; 
> Zaadopslagcapaciteit, zoals vriezers of koude kamers, gelamineerde foliezakken, lamineerapparaat.

Specifiek voor cryo-conservering:

$>$ Stikstofvaten, inclusief houders, buisjes, flesjes, stikstof;

$>-5^{\circ} \mathrm{C}$ vriezer;

$>$ controlled-rate vriezer;

$>$ incubator $\left(-10^{\circ} \mathrm{C}\right.$ tot $\left.+50^{\circ} \mathrm{C}\right)$ voor uitvoeren uitdrogingstoetsen;

$>$ registratiesysteem voor bewaring en recovery van materiaal.

\subsection{Kostenraming voor back-upcollecties}

Investeringen om deze faciliteiten op te zetten (kapitaalinvesteringen) worden in deze berekening niet meegenomen. Er wordt van uitgegaan dat gebruik kan worden gemaakt van al bestaande faciliteiten bij CGN-PGR en CGN-AnGr (< $1 \%$ uitbreiding van huidige capaciteit) en dat er alleen kosten zijn voor gebruik van faciliteiten, onderhoud en vervanging apparatuur. Initiële investeringen, zoals aanschaf van vriezers, stikstofvaten nodig om boomzaad collecties aan te leggen, worden wel meegenomen. De kosten van de opslag zelf worden ook bepaald door de omvang van de collectie (aantal populaties, aantal zaden per populatie, grootte zaden). Geschat wordt dat per collectie minimaal 5000 zaden opgeslagen moeten worden, nodig voor de collectie zelf, kiemingstesten bij aanvang, monitoring levensvatbaarheid en uitgifte voor herstelprojecten. Voor zeer zeldzame soorten zal dit niet haalbaar zijn en is het streven 500 zaden per populatie. Uitgaande van relatief grote zaden bij boomsoorten is de benodigde opslagcapaciteit per collectie ca. 0,075 L. Naast faciliteiten, consumables en specifieke apparatuur zijn de belangrijkste kosten arbeid. Arbeidskosten zitten voornamelijk in de stappen van zaadverzameling, verwerking tot opslag en in voorbereiding en onderzoek. Voor het verwerken van één zaadcollectie na oogst, inclusief zaadopslag en vastleggen van de documentatie, wordt geschat dat 2,5 dag nodig is. Voor de berekening hieronder is uitgegaan van een gemiddelde collectie qua omvang.

In onderstaand overzicht worden de kosten gepresenteerd voor het aanleggen van back-upcollecties voor 42 boom- en struiksoorten.

Tabel 4.2 Kostenraming van het aanleggen van back-upzaadcollecties.

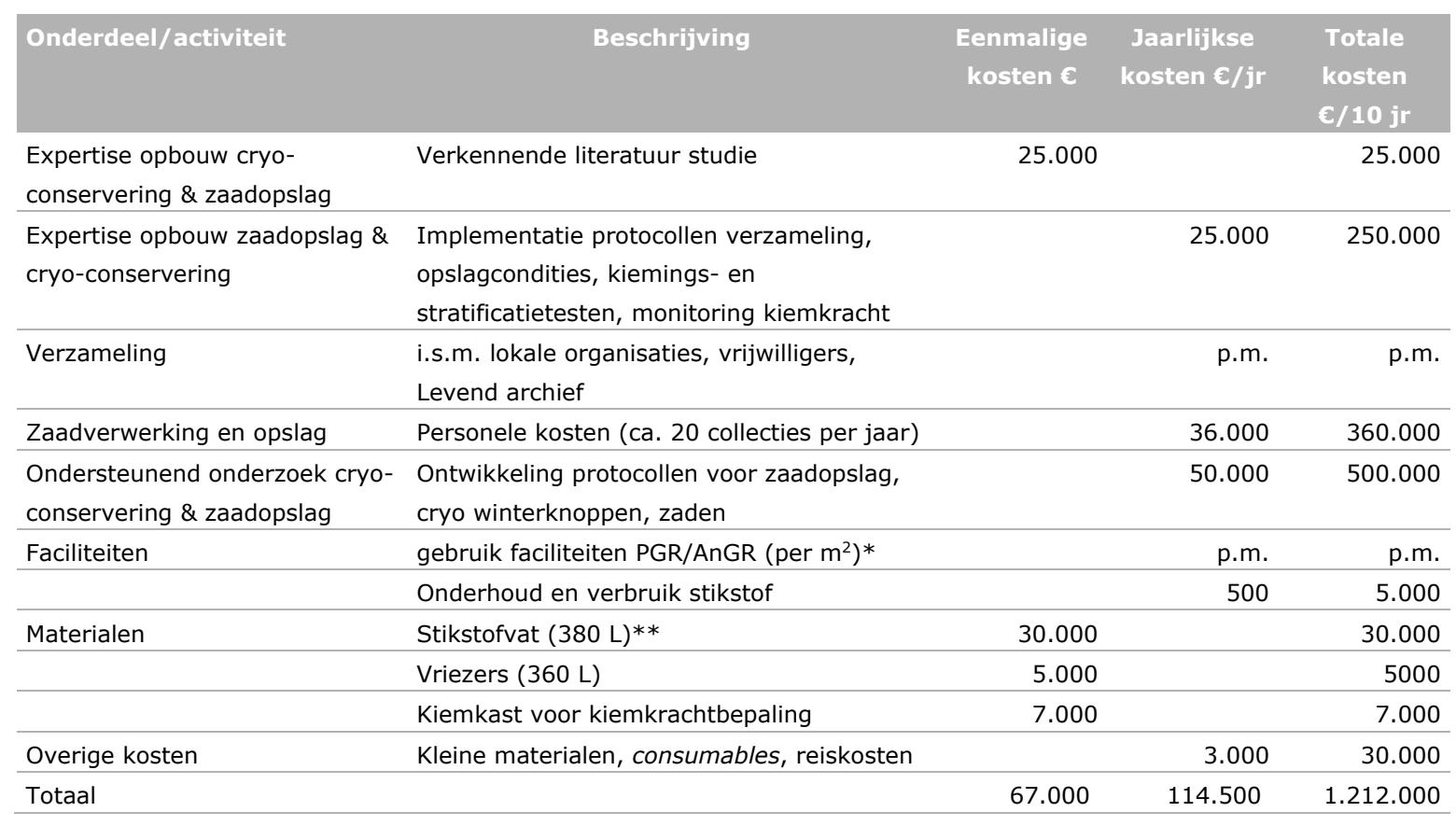

* uitbreiding van huidige capaciteit $<1 \%$

$* *$ lagere kosten bij gebruik kleine vaten 


\section{$5 \quad$ Samenvatting en aanbevelingen}

In de voorgaande hoofdstukken zijn de acties en maatregelen besproken die nodig zijn voor een duurzame instandhouding en ontwikkeling van de genenbank voor inheemse bomen en struiken. De maatregelen betreffen het verbeteren van de groeiplaatsomstandigheden van Roggebotzand, de inrichting en het operationeel beheer van de genenbank. Daarnaast zijn scenario's geschetst hoe de collectiesamenstelling verder ontwikkeld kan worden en ten slotte worden mogelijkheden voor het aanleggen van back-upcollecties besproken voor het borgen van de veiligheid van de collecties. Hieronder worden per onderdeel de voor- en nadelen van de maatregelen en scenario's besproken, inclusief financiële consequenties, en worden aanbevelingen gedaan.

\subsection{Inrichting en operationeel beheer van Roggebotzand}

De verbetermaatregelen die nodig zijn om Roggebotzand als genenbanklocatie te behouden, hebben betrekking op de bodem, waterhuishouding, faunabeheer, recreatie en registratie en monitoring van de collectie. De kosten van deze maatregelen bedragen gezamenlijk $€ 881.000$ en betreffen een eenmalige investering boven op de reguliere beheerkosten van de genenbank.

In de huidige situatie voldoen de standplaatscondities en het operationele beheer van Roggebotzand niet om de collecties duurzaam in stand te houden. Een slechte vitaliteit van de collecties verhoogt de kans op uitval van accessies en heeft ook invloed op de zaadzetting en daarmee het gebruik van de collecties. Deze eenmalige investering in Roggebotzand zal de vitaliteit van de bomen en struiken verbeteren en daarmee ook de oogst van zaden en stek. Met gezonde, groeikrachtige planten kan het verlies van genetisch materiaal in de collecties geminimaliseerd worden en daarnaast kunnen onnodige kosten die nu gemaakt worden (denk aan bestrijden van droogte- en hittestress, extra bemesting, onderhoud en inboeten) mogelijk omlaag. Het niet uitvoeren van deze eenmalige investeringen in Roggebotzand betekent dat het toch al intensieve onderhoud nog intensiever zal worden en daarmee de jaarlijkse kosten alleen maar zullen toenemen. Een alternatief voor het uitvoeren van eenmalige investeringen in de locatie Roggebotzand is de collectie verplaatsen naar een andere locatie. In technisch opzicht biedt de gehele genenbank verplaatsen vele voordelen. Een nieuwe genenbank opzetten biedt o.a. de mogelijkheid om een groeiplaats te kiezen die beter aansluit bij de meeste soorten (rijkere bodem), om een opzet onder kwekerij gelijkende omstandigheden te kiezen met gebruik van moderne teelttechnieken i.p.v. in een 'bosomgeving' en een slimme indeling van de gewassen over de percelen. De financiële consequenties van 'Roggebotzand verlaten' zijn in dit implementatieplan niet in detail uitgezocht. Duidelijk is echter dat dit een dure optie is doordat kwekerijgrond gepacht of aangekocht moet worden en er hoge kosten zijn voor het verplaatsen of kopiëren van de collectie. De totale kosten worden geschat op $€ 8.000 .000$ (zie paragraaf 2.6) en zijn vele malen hoger dan de eenmalige investeringen in Roggebotzand. Daarnaast worden eerder gedane investeringen m.b.t. de huidige genenbanklocatie hiermee tenietgedaan.

\section{Aanbevelingen}

- Aanbevolen wordt om de locatie Roggebotzand aan te houden, met als harde voorwaarde dat de genoemde verbetermaatregelen t.a.v. de groeiplaats en het beheer worden gerealiseerd. Met deze eenmalige investeringen kan de locatie Roggebotzand geschikt gemaakt worden voor een groot deel van de collectie. Het belangrijkste argument om Roggebotzand aan te houden, is dat het verplaatsen van een collectie of opnieuw opzetten onder kwekerijomstandigheden als financieel en praktisch onhaalbaar wordt gezien.

- Voor soorten die een rijke bodem vragen, blijft het advies deze te verplaatsen. Voor deze zogenaamde meer eisende soorten, waaronder Malus, Pyrus, en Rosa spp. is deze actie al in gang gezet met het in gebruik nemen van twee nevenlocaties (Hollandse Hout-Zuid en Lelystad-Noord). Primair liggen alle drie locaties in Flevoland, wat qua organisatie en logistiek werkbaar is. 
- Voor soorten waarvoor de groeiplaatsomstandigheden van Roggebotzand (of de nevenlocaties Hollandse Hout-Zuid en Lelystad-Noord) geheel niet geschikt zijn, is het advies dit materiaal op een andere manier te conserveren (zie ook aanleg zaadcollecties en scenario 2B, opbouw collecties).

\subsection{Opbouw collecties}

De toekomstige ontwikkeling van de genenbank qua opbouw van de collecties (soorten en accessies) is uitgewerkt aan de hand van twee scenario's: een minimale ontwikkeling en een optimale ontwikkeling met elk twee varianten. In deze scenario's is een onderscheid gemaakt tussen soorten waarvoor bescherming via de genenbank essentieel is (prioritaire soorten) en soorten die zijn opgenomen in de genenbank met als doel op een kostenefficiënte manier zaad te oogsten (complementaire soorten). In de scenario's zijn de kosten van de complementaire soorten apart berekend. Voor deze groep zijn de jaarlijkse kosten voor onderhoud onder scenario $1 \mathrm{~A}$ berekend op $€$ 88.382. Optimalisatie van het aantal kopieën per accessie en accessiesamenstelling is hier niet doorberekend.

De twee scenario's met elk twee varianten, waarvoor de beheerkosten zijn doorgerekend, zijn alle afwijkingen van het huidige beheer van de genenbank. Het huidige beheer is suboptimaal. Zo worden er nu bijvoorbeeld extra kosten gemaakt voor onkruidbestrijding, bemesting en water geven, omdat het terrein niet op orde is. In de berekeningen is uitgegaan van 'gewenst' beheer (zie ook paragraaf 3.5). De baseline is scenario $1 \mathrm{~A}$, namelijk de kosten om de genenbank in de huidige omvang in stand te houden op basis van 'gewenst' beheer. In Tabel 5.1 wordt een samenvatting gegeven van de verschillende scenario's en kosten.

Tabel 5.1 Overzicht scenario's collectieonderhoud en kosten.

\begin{tabular}{lll} 
Collectie opbouw & Scenario & Jaarljkse kosten E/jr \\
prioritaire soorten & $1 \mathrm{~A}$ & 99085 \\
\hline prioritaire soorten & $1 \mathrm{~B}$ & 127824 \\
\hline prioritaire soorten & $2 \mathrm{~A}$ & 169042 \\
\hline prioritaire soorten & $2 \mathrm{~B}$ & $140339 *$ \\
\hline
\end{tabular}

* exclusief 12 soorten in zaadbankcollecties.

Scenario Minimaal 1A betekent handhaving van de status quo. De jaarlijkse kosten voor onderhoud en vervanging bedragen $€ 99.085$ voor de prioritaire soorten. Een voordeel van dit scenario is dat de kosten het laagst zijn. Een nadeel is dat dit scenario geen verdere ontwikkeling van de genenbank inhoudt en de suboptimale opbouw van de collectie in stand wordt gehouden. Dit geldt zowel voor het aantal kopieën van een accessie (soms te veel, in andere gevallen te weinig), voor 'gaps' in de collectie alsook voor het ontbreken van 19 prioritaire soorten in de genenbank (Tabel 3.1).

Scenario Minimaal 1B is een variant op het handhaven van de status quo waarbij het aantal kopieën per accessie wordt aangepast. In dit geval wordt gewerkt met 5 of 10 kopieën per accessie voor resp. bomen en struiken, wat ruim voldoende is voor genenbehoud en voldoende zou moeten zijn voor zaadoogst. De kosten van deze variant zijn $€ 127.824$ voor de prioritaire soorten; hoger dan bij $1 \mathrm{~A}$. Stijging van de kosten komt doordat per saldo het aantal individuen zal toenemen. Voordeel van dit scenario is dat er efficiënter wordt omgegaan met ruimte en middelen om bomen te onderhouden. Nadeel van dit scenario is dat dit praktisch slecht uitvoerbaar is. Dit is ruimtelijk een grote puzzel. Ook het verwijderen van bomen enkel om deze reden is een extra kostenpost. Het lijkt het meest logisch deze variant uit te voeren als dit ingepast kan worden in de reguliere vervangingscyclus (vervanging afgedragen bomen) of bij inboetwerkzaamheden van accessies die dreigen uit te vallen.

Scenario Optimaal 2A schetst een toekomstbeeld van de genenbank waarbij de accessie-samenstelling wordt geoptimaliseerd en ontbrekende prioritaire soorten worden toegevoegd. De kosten voor dit scenario zijn geschat op $€ 169.042$ per jaar voor de prioritaire soorten. Met dit scenario wordt de rol 
van de genenbank als 'last resort' het best bereikt. De genetische variatie per collectie zal toenemen en het aantal soorten in de genenbank wordt uitgebreid met 19 soorten. Hierdoor kan in de toekomst ook beter ingespeeld worden op de vraag naar genetisch divers plantmateriaal. Dit geldt ook voor soorten waarvan nu vanuit in situ niet geoogst kan worden, omdat populaties te klein zijn zoals bij o.a. Malus sylvestris (Figuur 5.1). Een minpunt is dat in dit scenario soorten worden opgenomen in de genenbank Roggebotzand die daar eigenlijk niet kunnen groeien. Dit zal extra onderhoudskosten met zich meebrengen en een groot risico inhouden op uitval van accessies en dus verlies van genetisch materiaal.



Figuur 5.1 Malus sylvestris De wilde appel is sterk bedreigd. Zaadoogst in de genenbankcollectie draagt bij aan het behoud van deze soort.

Scenario Optimaal 2B is een efficiëntere variant van Optimaal $2 \mathrm{~A}$ in die zin dat voor soorten die eigenlijk niet thuishoren op het Roggebotzand een alternatief is gezocht. Genista anglica is een voorbeeld waarvoor geprobeerd is een collectie aan te leggen op Roggebotzand, maar die er slecht bij staat door te veel uitval na jaren (10-25\% na 3 jaar), veronkruiding, matige zaadproductie, schade door nachtvorst en waarvoor een alternatief gekozen moet worden. De kosten voor deze variant bedragen $€ 140.339$ per jaar voor onderhoud voor de prioritaire soorten. Deze jaarlijkse kosten zijn lager dan bij scenario $2 \mathrm{~A}$, omdat 12 soorten niet worden opgenomen in de veldcollectie. In dit scenario is gekozen deze soorten in een zaadbank te behouden. Het aanleggen van zaadcollecties is het meest praktisch en kostenefficiëntst voor deze soorten. Een andere mogelijkheid is deze specifieke en veeleisende soorten, waaronder nogal wat halfheesters, op een kwekerij in stand houden. Dit alternatief is in dit implementatieplan niet voldoende onderzocht. De kosten voor het aanleggen van zaadcollecties van deze soorten als alternatief worden geschat op $€ 303.000$ ( $€ 30.300$ per jaar wanneer aangelegd in een periode van tien jaar).

De kosten van de scenario's zullen zich in de loop van de jaren richting de berekende kosten bewegen. Kosten voor nieuwe aanplant bij optimalisatie aantal kopieën en uitbreiding van accessies en soorten zullen uitgespreid worden over meerdere jaren. Bovenop deze aanplant- en beheerkosten beschreven 
in deze scenario's zijn er nog aanvullende kosten voor algemeen terreinonderhoud (zie paragraaf 3.7). In Figuur 5.2 wordt een voorbeeld gegeven hoe kosten zich kunnen ontwikkelen over een periode van tien jaar voor scenario $2 \mathrm{~B}$, inclusief aanleggen van zaadcollecties. Het huidige budget voor het onderhouden van de genenbank (prioritaire en complementaire soorten) is $€ 250.000$ per jaar (LNV subsidie voor beheer genenbank Roggebotzand, onderdeel van kaderbrief SBB).

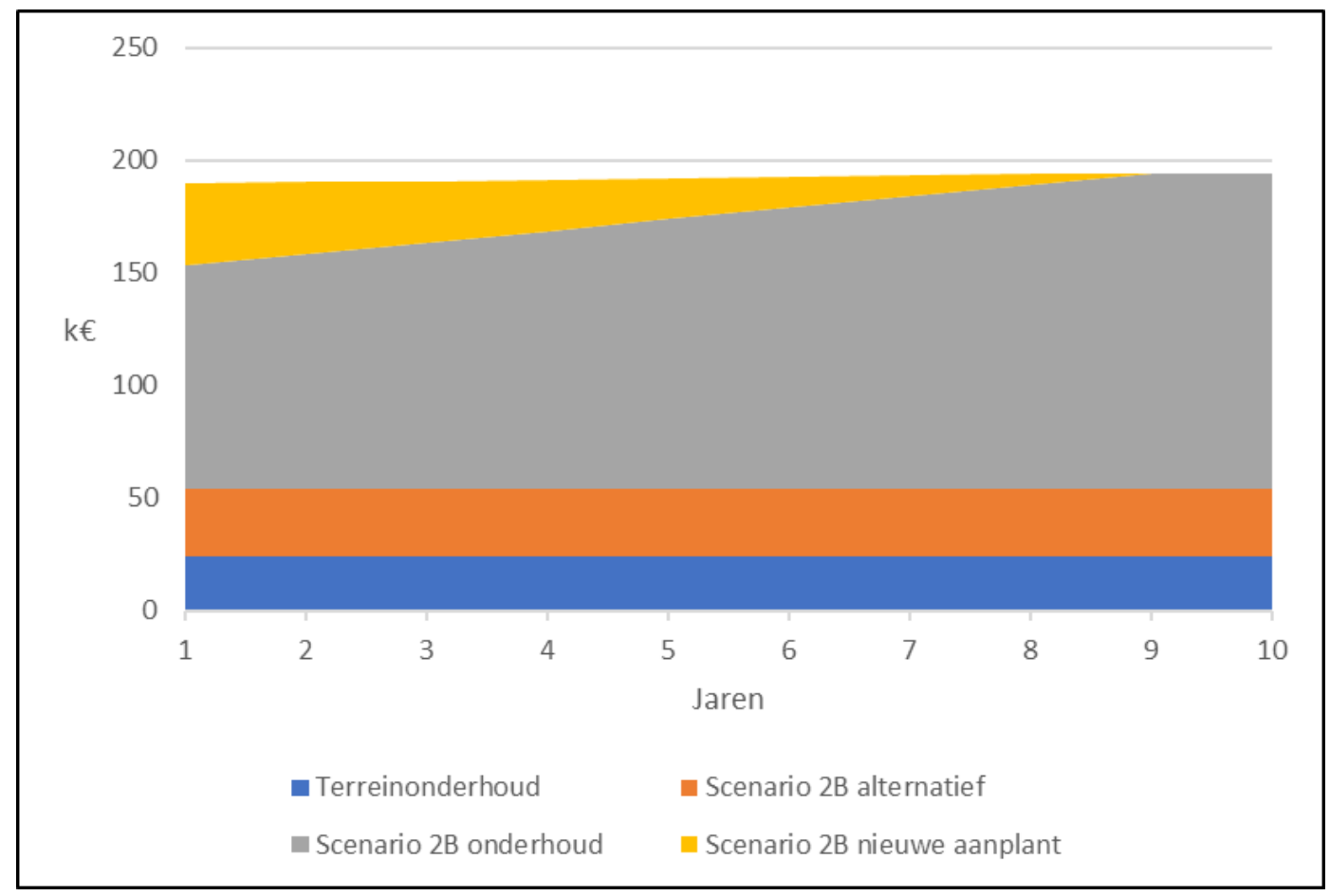

Figuur 5.2 Voorbeeld ontwikkeling kosten over tien jaar voor scenario 2B (onderhoud, nieuwe aanplant en aanleg zaadcollecties als alternatief) plus kosten algemeen terreinonderhoud.

\section{Aanbevelingen}

- Aanbevolen wordt de genenbank verder te ontwikkelen conform scenario 2B over een periode van 5-10 jaar. In dit scenario wordt voor 12 soorten die niet in Roggebotzand, Hollandse Hout-Zuid en Lelystad thuishoren, als alternatief een zaadcollectie aangelegd.

- Met scenario 2B kunnen de veld- en zaadcollecties optimaal bijdragen aan het bevorderen van het gebruik van autochtoon plantmateriaal (conform ambities Bossenstrategie) en aan herintroductie van materiaal of het versterken van kwetsbare in-situpopulaties. Deze link met in-situbehoud is belangrijk en geadviseerd wordt in de toekomst gebruik uit de collecties te monitoren (bijv. door vast te leggen waar herintroductie/herstelprojecten worden uitgevoerd).

- In dit implementatieplan is niet gekeken hoe de kosten van de scenario's zich verhouden tot de werkelijke huidige kosten voor het beheer. Met de eenmalige investering in het verbeteren van de locatie Roggebotzand van $€ 881.000$ is de verwachting dat specifiek beheer om calamiteiten (denk aan periodiek water geven i.v.m. droogte en hittestress) te bestrijden op termijn goedkoper wordt. Geadviseerd wordt dat SBB in een vervolgstap uitwerkt hoe huidige beheerkosten zich zullen ontwikkelen, nadat verbeter- en herstelmaatregelen zijn doorgevoerd.

- De behoefte aan zaad is groeiende i.v.m. meer aanleg bos en beplantingen in de komende jaren (zie ook uitgangspunten Bossenstrategie (LNV, 2020)). In de geschetste scenario's is gerekend met 5 en 10 individuen per accessie. Het is aan te bevelen een analyse te maken van de benodigde zaadproductiecapaciteit op basis van een prognose van de zaadbehoefte op middellange termijn en eventueel het aantal individuen per accessie in de collectie hierop aan te passen. 


\subsection{Back-upcollecties}

Onderzocht is hoe de veiligheid van de Roggebotzand-collecties geborgd kan worden door het aanleggen van back-up-/duplicaatcollecties. Het aanleggen van zaadcollecties lijkt het meest voor de hand liggend hiervoor, omdat het 1) kostenefficiënter is dan het dupliceren van de Roggebotzandcollectie op een andere locatie, 2) niet buiten is, waardoor risico's op verlies van materiaal door ziekten en plagen gering zijn, 3) technisch haalbaar is voor de meeste inheemse boom- en struiksoorten in Nederland en 4) geschikt is voor langetermijnbewaring. Er is een schatting gemaakt van de eenmalige en jaarlijkse kosten om in een tijdsbestek van tien jaar voor ca. 42 soorten zaadcollecties aan te leggen, inclusief kosten voor expertise opbouw en ondersteunend onderzoek (schatting ca. $€$ 1.212.000). Voor het uitrollen van een back-upstrategie zullen extra middelen beschikbaar moeten komen, boven op de huidige financiering van de wettelijke onderzoekstaken genetische bronnen (WOT Genetische Bronnen).

\section{Aanbeveling}

- Geadviseerd wordt te kiezen voor het opzetten van back-upcollecties in de vorm van een zaadbank.

- Aanbevolen wordt te starten met soorten die het risicovolst en kwetsbaarst zijn en die niet opgenomen kunnen worden in de veldcollectie van Roggebotzand i.v.m. ziekte en ongeschiktheid van de groeiplaats (Tabel 3.1). Het betreft de soorten waarvoor onder scenario $2 \mathrm{~A}$ een alternatief gezocht wordt. De aanleg van zaadcollecties onder scenario 2A en de bijkomende kosten komen dan te vervallen. 


\section{Literatuur}

Buiteveld, J., Copini, P. (2019). Evaluatie van de genenbank voor inheemse bomen en struiken: strategie, gewenste omvang en kwaliteit van de genenbank Roggebotzand. Wageningen: Centre for Genetic Resources, the Netherlands (CGN), CGN rapport 44, Wageningen University \& Research.

Jenderek, M.M., Reed, B.M. (2017). Cryopreserved storage of clonal germplasm in the USDA National Plant Germplasm System. In Vitro Cell.Dev.Biol._Plant, DOI 10.1007/s11627-017-9828-3

Kew, R.B.G. (2020). Seed Information Database (SID). Version 7.1. Available from: http://data.kew.org/sid/ (July 2020).

Li, D. and H.W. Pritchard (2009). The science and economics of ex situ plant conservation. Cell Press 614-621.

LNV, VROM en OSW (2002). Nota Bronnen van ons bestaan: behoud en duurzaamheid van genetische diversiteit. Ministerie van Landbouw, Natuurbeheer en Visserij, Den Haag.

LNV (2020). Bos voor de toekomst. Uitwerking ambities en doelen landelijke Bossenstrategie en beleidsagenda 2030. Ministerie van Landbouw, Natuurbeheer en Visserij, Den Haag.

Maes, B. (2016). Atlas van het landschappelijk groen erfgoed van Nederland. Rijksdienst voor het Cultureel Erfgoed. Cultuurhistorisch waardevolle bossen, houtwallen en heggen. Amersfoort.

Pence, V.C. (2011) Evaluating costs for in vitro propagation and preservation of endangered plants. In Vitro Cell Dev Biol Plant 47:176-187.

Raffe, J.K. van en J.J. de Jong (2020). Normenboek Natuur, Bos en Landschap 2020. Wageningen, Wageningen Environmental Research, $180 \mathrm{p}$.

Schaminée, J., N. van Rooijen \& J. Buiteveld (2020). Rozen in de genenbank: advies voor opname van rozen taxa in de genenbank voor inheemse bomen en struiken. Centre for Genetic Resources, the Netherlands (CGN), CGN rapport 50, Wageningen University \& Research. 62 p.

Schroeder, J. (2013). Die Wild-Birne (Pyrus pyraster) in Deutschland - Ergebnisse einer bundesweiten Inventur. Archiv für Forstwesen und Landschaftsökologie, 47: 1-12.

Wegerif, K., de Haan, J., Van de Vlucht, S., Groenestein, M. (2019). Herstel waterhuishouding Roggebotzand. BBB Specialisatie Beheer Bos en Natuur 2018 -2019. Van Hall Larenstein University of Applied Sciences, Velp, 39 pp. 


\section{Bijlage 1 Kaarten sloten Roggebotzand}
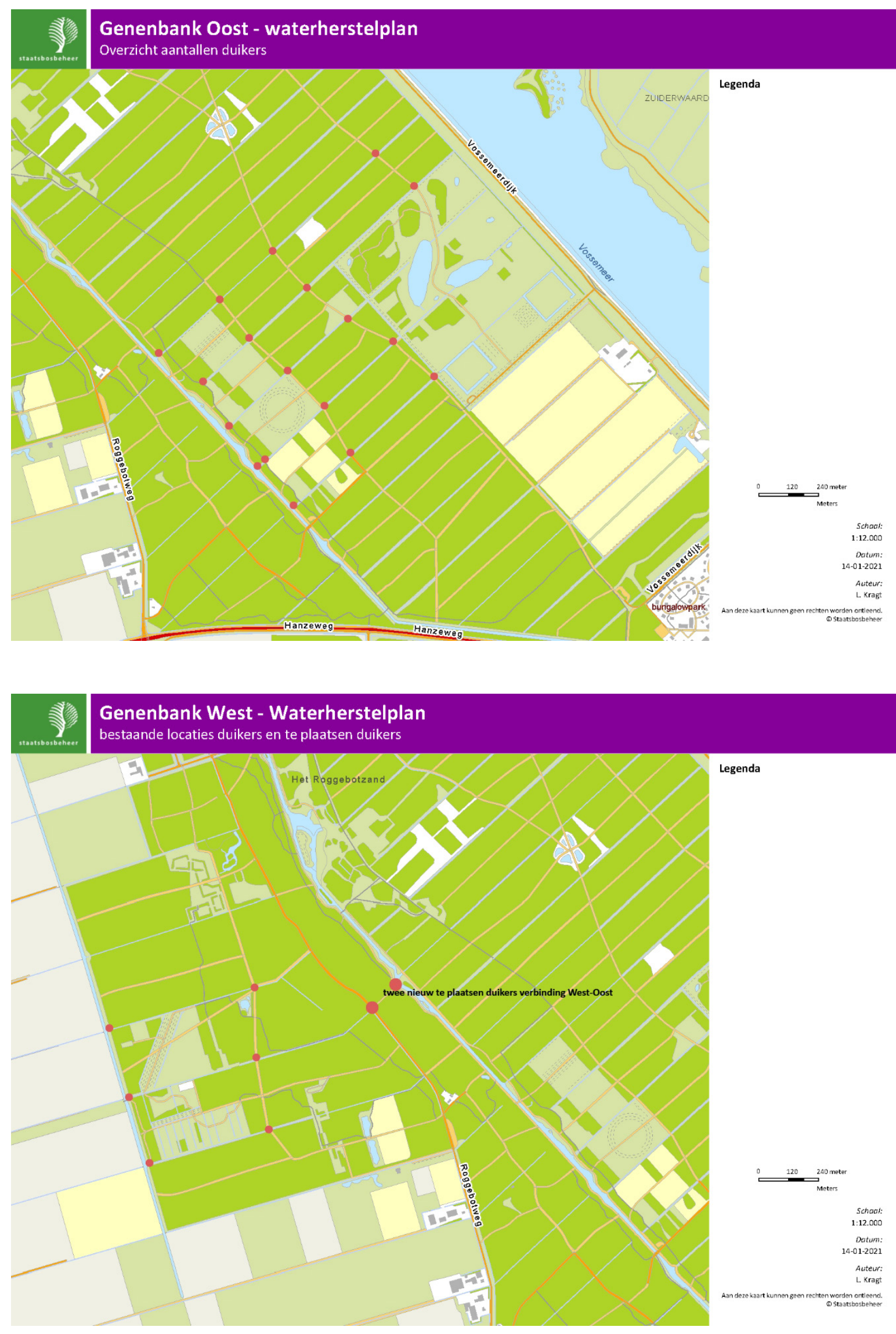






\section{Bijlage 2 Uitbreiding accessies in genenbank per soort}

\begin{tabular}{|c|c|c|c|c|c|}
\hline $\begin{array}{l}\text { Wetenschappelijke } \\
\text { naam }\end{array}$ & Nederlandse naam & $\begin{array}{l}\text { Categorie } \\
\text { bomen of } \\
\text { struiken }\end{array}$ & $\begin{array}{l}\text { Geschiktheid } \\
\text { genenbank }\end{array}$ & $\begin{array}{l}\text { Scenario } 2 \mathrm{~A} \\
\text { Geschatte uitbreiding } \\
\text { (accessies) in vier } \\
\text { categorieën } \\
(1-10,11-25,26-50 \text {, } \\
51-100)\end{array}$ & $\begin{array}{l}\text { Scenario 2B } \\
\text { Soorten } \\
\text { alternatieve } \\
\text { conserverings- } \\
\text { strategie }\end{array}$ \\
\hline Acer campestre & Spaanse aak/veldesdoorn & Boom groot & Goed & $11-25$ & \\
\hline Andromeda polifolia & Lavendelhei & Struik klein & Ongeschikt & & $\mathrm{Ja}$ \\
\hline Arctostaphylos uva-ursi & berendruif & Struik klein & Slecht & $11-25$ & $\mathrm{Ja}$ \\
\hline Berberis vulgaris & zuurbes & Struik groot & Goed & $1-10$ & \\
\hline Cornus mas & gele kornoelje & Struik groot & Voldoende & $1-10$ & \\
\hline Cornus sanguinea & rode kornoelje & Struik groot & Voldoende & $1-10$ & \\
\hline Crataegus laevigata & tweestijlige meidoorn & Struik groot & Voldoende & $1-10$ & \\
\hline Crataegus $x$ macrocarpa & grootvruchtige meidoorn & Struik groot & Voldoende & $1-10$ & \\
\hline Crataegus $x$ subsphaericea & schijnkoraalmeidoorn & Struik groot & Voldoende & $1-10$ & \\
\hline Daphne mezereum & rood peperboompje & Struik klein & Slecht & $11-25$ & $\mathrm{Ja}$ \\
\hline Erica cinerea & rode dopheide & Struik klein & Slecht & $26-50$ & $\mathrm{Ja}$ \\
\hline Fraxinus excelsior & gewone es & Boom groot & Ongeschikt (ziekte) & & $\mathrm{Ja}$ \\
\hline Genista anglica & stekelbrem & Struik klein & Slecht & $11-25$ & $\mathrm{Ja}$ \\
\hline Genista germanica & Duitse brem & Struik klein & Slecht & $26-50$ & $\mathrm{Ja}$ \\
\hline Genista pilosa & kruipbrem & Struik klein & Slecht & $51-100$ & $\mathrm{Ja}$ \\
\hline Genista tinctoria & verfberm & Struik klein & Slecht & $51-100$ & $\mathrm{Ja}$ \\
\hline Juniperus communis & jeneverbes & Boom klein & Matig & $26-50$ & \\
\hline Ligustrum vulgare & wilde liguster & Struik groot & Goed & $1-10$ & \\
\hline Lonicera xylosteum & rode kamperfoelie & Struik groot & Goed & & \\
\hline Malus sylvestris & wilde appel & Boom klein & Goed & $1-10$ & \\
\hline Myrica gale & wilde gagel & Struik klein & Slecht & $51-100$ & $\mathrm{Ja}$ \\
\hline Populus nigra & zwarte populier & Moerstoof & Voldoende & & \\
\hline Pyrus pyraster & Wilde peer & Boom klein & Voldoende & $1-10$ & \\
\hline Rhamnus cathartica & wegedoorn & Struik groot & Goed & & \\
\hline Ribes nigrum & zwarte bes & Struik klein & Voldoende & & \\
\hline Ribes rubrum & aalbes & Struik klein & Voldoende & $1-10$ & \\
\hline Ribes uva-crispa & kruisbes & Struik klein & Voldoende & $1-10$ & \\
\hline Rosa agrestis & kraagroos & Struik groot & Voldoende & $11-25$ & \\
\hline Rosa arvensis & bosroos & Struik groot & Goed & $1-10$ & \\
\hline Rosa tomentella & beklierde heggenroos & Struik groot & Voldoende & $11-25$ & \\
\hline Rosa caesia & behaarde struweelroos & Struik groot & Voldoende & $1-5$ & \\
\hline Rosa vosagiaca & kale struweelroos & Struik groot & Voldoende & $1-10$ & \\
\hline Rosa elliptica & wigbladige roos & Struik groot & Voldoende & $1-5$ & \\
\hline Rosa micrantha & kleinbloemige roos & Struik groot & Voldoende & $26-50$ & \\
\hline Rosa rubiginosa & egelantier & Struik groot & Goed & $11-25$ & \\
\hline Rosa sherardii & berijpte viltroos & Struik groot & Voldoende & $1-5$ & \\
\hline Rosa tomentosa & viltroos & Struik groot & Goed & & \\
\hline Salix aurita & geoorde wilg & Moerstoof & Goed & $1-10$ & \\
\hline Salix fragilis & kraakwilg & Moerstoof & Goed & $11-25$ & \\
\hline Salix pentandra & laurierwilg & Moerstoof & Goed & & \\
\hline Salix purpurea & bittere wilg & Moerstoof & Goed & $11-25$ & \\
\hline Salix repens & kruipwilg & Moerstoof & Goed & & \\
\hline Sambucus racemosa & trosvlier & Boom klein & Matig/voldoende & $1-10$ & \\
\hline Taxus baccata & taxus & Boom klein & Matig & & \\
\hline Tilia cordata & winterlinde & Boom groot & Voldoende & $1-10$ & \\
\hline Tilia platyphyllos & zomerlinde & Boom groot & Voldoende & $26-50$ & \\
\hline Ulex europaeus & gaspeldoorn & Struik groot & Onduidelijk & $26-50$ & \\
\hline Ulmus glabra & ruwe iep & Boom groot & Ongeschikt (ziekte) & & $\mathrm{Ja}$ \\
\hline Ulmus laevis & fladderiep/steeliep & Boom groot & Voldoende & $1-10$ & \\
\hline Vaccinium uliginosum & rijsbes & Struik klein & Slecht & $11-25$ & $\mathrm{Ja}$ \\
\hline Viburnum lantana & wollige sneeuwbal & Struik groot & Onduidelijk & $1-10$ & \\
\hline
\end{tabular}




\section{Bijlage 3 Maatregelen voor aanleg en onderhoud}

Overzicht van maatregelen voor aanleg (vervangen) en onderhoud. Aangegeven zijn de maatregel/activiteit, het percentage waarop de bewerking van toepassing is, het interval waarmee dit wordt uitgevoerd en de frequentie. Als voorbeeld: het water geven (na aanplant) van bomen gebeurt bij alle bomen (100\%), per 20 jaar (interval) 10 maal (frequentie).

\begin{tabular}{|c|c|c|c|c|c|}
\hline maatregel & activiteit & bewerking & Interval (jr) & frequentie & euro/eenheid \\
\hline \multicolumn{6}{|l|}{ boom klein } \\
\hline aanleg & Uitzetten plantplekken & $100 \%$ & 20 & 1,0 & 0,42 \\
\hline aanleg & boom klein & $100 \%$ & 20 & 1,0 & 5,00 \\
\hline aanleg & Lossen, inkuilen en laden veren & $100 \%$ & 20 & 1,0 & 0,42 \\
\hline aanleg & Woelen plantplaatsen & $100 \%$ & 20 & 1,0 & 0,50 \\
\hline aanleg & $\begin{array}{l}\text { Planten bewortelde stek (populier/wilg) - in } \\
\text { geboorde gaten, per } 100 \text { stuks }\end{array}$ & $100 \%$ & 20 & 1,0 & 0,84 \\
\hline aanleg & Water geven jonge aanplant & $100 \%$ & 20 & 10,0 & 6,70 \\
\hline aanleg & Bemesten plantspiegels - met stalmest of compost & $100 \%$ & 20 & 1,0 & 5,40 \\
\hline inboet & boom klein & $10 \%$ & 20 & 1,0 & 0,50 \\
\hline inboet & Lossen, inkuilen en laden bomen & $10 \%$ & 20 & 1,0 & 0,12 \\
\hline inboet & Woelen plantplaatsen & $10 \%$ & 20 & 1,0 & 0,50 \\
\hline inboet & $\begin{array}{l}\text { Planten bewortelde stek (populier/wilg) - in } \\
\text { geboorde gaten, per } 100 \text { stuks }\end{array}$ & $10 \%$ & 20 & 1,0 & 0,84 \\
\hline inboet & Water geven jonge aanplant & $10 \%$ & 20 & 10,0 & 0,67 \\
\hline aanleg & Plaatsen boompalen & $100 \%$ & 20 & 1,0 & 31,50 \\
\hline aanleg & Verwijderen boompalen & $100 \%$ & 20 & 1,0 & 0,83 \\
\hline aanleg & Laden boompalen. & $100 \%$ & 20 & 1,0 & 0,40 \\
\hline bemesten & Bemesten plantspiegels - met stalmest of compost & $100 \%$ & 4 & 1,0 & 5,40 \\
\hline maaien & Klepelen ruige vegetatie & $100 \%$ & 1 & 4,0 & 0,99 \\
\hline onkruid & Schoffelen/hakken boomspiegels & $30 \%$ & 1 & 4,0 & 1,38 \\
\hline maaien & Bijmaaien rond bomen - per 100 obstakels & $70 \%$ & 1 & 2,0 & 0,74 \\
\hline snoeien & Correctiesnoei bomen & $60 \%$ & 20 & 5,0 & 1,38 \\
\hline snoeien & Snoeien overblijvende struiken & $60 \%$ & 20 & 1,0 & 0,99 \\
\hline snoeien & Versnipperen snoeihout van hopen & $60 \%$ & 20 & 1,0 & 0,50 \\
\hline snoeien & Snoeien bomen - met ladder & $100 \%$ & 20 & 2,0 & 13,20 \\
\hline snoeien & Versnipperen snoeihout van bomen & $100 \%$ & 20 & 2,0 & 19,80 \\
\hline verwijderen & $\begin{array}{l}\text { Vellen bomen langs wegen, uitsnoeien, korten en } \\
\text { stapelen }\end{array}$ & $100 \%$ & 20 & 1,0 & 26,80 \\
\hline verwijderen & Stobben frezen, matig zware stobbenfrees & $100 \%$ & 20 & 1,0 & 4,87 \\
\hline \multicolumn{6}{|l|}{ boom groot } \\
\hline aanleg & Uitzetten plantplekken & $100 \%$ & 30 & 1,0 & 0,50 \\
\hline aanleg & boom groot & $100 \%$ & 30 & 1,0 & 5,00 \\
\hline aanleg & Lossen, inkuilen en laden veren & $100 \%$ & 30 & 1,0 & 0,42 \\
\hline aanleg & Woelen plantplaatsen & $100 \%$ & 30 & 1,0 & 0,50 \\
\hline aanleg & $\begin{array}{l}\text { Planten bewortelde stek (populier/wilg) - in } \\
\text { geboorde gaten, per } 100 \text { stuks }\end{array}$ & $100 \%$ & 30 & 1,0 & 0,84 \\
\hline aanleg & Water geven jonge aanplant & $100 \%$ & 30 & 10,0 & 6,70 \\
\hline aanleg & Bemesten plantspiegels - met stalmest of compost & $100 \%$ & 30 & 1,0 & 5,40 \\
\hline inboet & boom groot & $10 \%$ & 30 & 1,0 & 0,50 \\
\hline inboet & Lossen, inkuilen en laden bomen & $10 \%$ & 30 & 1,0 & 0,12 \\
\hline inboet & Woelen plantplaatsen & $10 \%$ & 30 & 1,0 & 0,50 \\
\hline inboet & $\begin{array}{l}\text { Planten bewortelde stek (populier/wilg) - in } \\
\text { geboorde gaten, per } 100 \text { stuks }\end{array}$ & $10 \%$ & 30 & 1,0 & 0,08 \\
\hline inboet & Water geven jonge aanplant & $10 \%$ & 30 & 10,0 & 0,67 \\
\hline aanleg & Plaatsen boompalen & $100 \%$ & 30 & 1,0 & 31,50 \\
\hline
\end{tabular}




\begin{tabular}{|c|c|c|c|c|c|}
\hline atregel & activiteit & bewerking & Interval (jr) & frequentie & euro/eenheid \\
\hline aanleg & Verwijderen boompalen & $100 \%$ & 30 & 1,0 & 0,83 \\
\hline aanleg & Laden boompalen & $100 \%$ & 30 & 1,0 & 0,40 \\
\hline bemesten & Bemesten plantspiegels - met stalmest of compost & $100 \%$ & 4 & 1,0 & 5,40 \\
\hline maaien & Klepelen ruige vegetatie & $100 \%$ & 1 & 4,0 & 3,94 \\
\hline onkruid & Schoffelen/hakken boomspiegels & $20 \%$ & 1 & 4,0 & 1,12 \\
\hline maaien & Bijmaaien rond bomen - per 100 obstakels & $80 \%$ & 1 & 2,0 & 0,85 \\
\hline snoeien & Waterlot snoeien & $10 \%$ & 1 & 1,0 & 0,11 \\
\hline snoeien & Correctiesnoei bomen & $100 \%$ & 30 & 5,0 & 2,30 \\
\hline snoeien & Snoeien bomen - met ladder & $100 \%$ & 30 & 2,0 & 13,20 \\
\hline snoeien & Versnipperen snoeihout van bomen & $100 \%$ & 30 & 2,0 & 19,80 \\
\hline snoeien & Snoeien bomen en versnipperen - met hoogwerker & $100 \%$ & 30 & 2,0 & 24,00 \\
\hline verwijderen & $\begin{array}{l}\text { Vellen bomen langs wegen, uitsnoeien, korten en } \\
\text { stapelen }\end{array}$ & $100 \%$ & 30 & 1,0 & 31,90 \\
\hline verwijderen & Stobben frezen, matig zware stobbenfrees & $100 \%$ & 30 & 1,0 & 5,80 \\
\hline \multicolumn{6}{|l|}{ struik klein } \\
\hline aanleg & $\begin{array}{l}\text { Uitzetten plantobject - van lijnelementen met } \\
\text { piketten }\end{array}$ & $100 \%$ & 15 & 1,0 & 0,06 \\
\hline aanleg & Frezen - met zode & $100 \%$ & 15 & 1,0 & 0,06 \\
\hline aanleg & struik klein & $100 \%$ & 15 & 1,0 & 5,00 \\
\hline aanleg & Lossen, inkuilen en laden bosplantsoen & $100 \%$ & 15 & 1,0 & 0,08 \\
\hline aanleg & Inboeten struiken & $100 \%$ & 15 & 1,0 & 0,73 \\
\hline aanleg & Water geven jonge aanplant & $100 \%$ & 15 & 10,0 & 6,70 \\
\hline aanleg & Bemesten plantgat & $100 \%$ & 15 & 1,0 & 2,30 \\
\hline inboet & struik klein & $10 \%$ & 15 & 1,0 & 0,50 \\
\hline inboet & Lossen, inkuilen en laden bosplantsoen & $10 \%$ & 15 & 1,0 & 0,01 \\
\hline inboet & Inboeten struiken & $10 \%$ & 15 & 1,0 & 0,07 \\
\hline inboet & Water geven jonge aanplant & $10 \%$ & 15 & 10,0 & 0,67 \\
\hline bemesten & Bemesten plantspiegels - met stalmest of compost & $100 \%$ & 4 & 1,0 & 2,70 \\
\hline snoeien & Snoeien overblijvende struiken & $50 \%$ & 1 & 1,0 & 0,83 \\
\hline snoeien & Versnipperen snoeihout van hopen & $50 \%$ & 1 & 1,0 & 0,41 \\
\hline snoeien & $\begin{array}{l}\text { Terugzetten beplanting, bomen of struiken (per } \\
\text { stuk) }\end{array}$ & $50 \%$ & 4 & 1,0 & 0,36 \\
\hline snoeien & Versnipperen snoeihout van hopen & $50 \%$ & 4 & 1,0 & 1,58 \\
\hline onkruid & $\begin{array}{l}\text { Schoffelen / hakken in struikbeplanting en } \\
\text { plantenperken }\end{array}$ & $100 \%$ & 15 & 4,0 & 1,06 \\
\hline onkruid & $\begin{array}{l}\text { Schoffelen / hakken in struikbeplanting en } \\
\text { plantenperken }\end{array}$ & $100 \%$ & 1 & 4,0 & 1,06 \\
\hline maaien & Maaien ruig gras, met ruwterreinmaaier & $100 \%$ & 1 & 8,0 & 0,11 \\
\hline verwijderen & Rooien struiken - met midi-graafmachine & $100 \%$ & 15 & 1,0 & 0,58 \\
\hline verwijderen & Versnipperen snoeihout van hopen & $100 \%$ & 15 & 1,0 & 3,15 \\
\hline \multicolumn{6}{|l|}{ struik groot } \\
\hline aanleg & $\begin{array}{l}\text { Uitzetten plantobject - van lijnelementen met } \\
\text { piketten }\end{array}$ & $100 \%$ & 20 & 1,0 & 0,48 \\
\hline aanleg & Frezen - met zode & $100 \%$ & 20 & 1,0 & 0,22 \\
\hline aanleg & struik groot & $100 \%$ & 20 & 1,0 & 5,00 \\
\hline aanleg & Lossen, inkuilen en laden bosplantsoen & $100 \%$ & 20 & 1,0 & 0,08 \\
\hline aanleg & Inboeten struiken & $100 \%$ & 20 & 1,0 & 0,73 \\
\hline aanleg & Water geven jonge aanplant & $100 \%$ & 20 & 10,0 & 6,70 \\
\hline aanleg & Bemesten plantgat & $100 \%$ & 20 & 1,0 & 2,30 \\
\hline inboet & struik groot & $10 \%$ & 20 & 1,0 & 0,50 \\
\hline inboet & Lossen, inkuilen en laden bosplantsoen & $10 \%$ & 20 & 1,0 & 0,01 \\
\hline inboet & Inboeten struiken & $10 \%$ & 20 & 1,0 & 0,07 \\
\hline inboet & Water geven jonge aanplant & $10 \%$ & 20 & 10,0 & 0,67 \\
\hline bemesten & Bemesten plantspiegels - met stalmest of compost & $100 \%$ & 4 & 1,0 & 5,40 \\
\hline snoeien & Snoeien overblijvende struiken & $50 \%$ & 1 & 1,0 & 1,65 \\
\hline snoeien & Versnipperen snoeihout van hopen & $50 \%$ & 1 & 1,0 & 0,66 \\
\hline snoeien & Vellen en bundelen essenhakhout & $50 \%$ & 10 & 1,0 & 0,95 \\
\hline snoeien & Versnipperen snoeihout van hopen & $50 \%$ & 10 & 1,0 & 3,60 \\
\hline onkruid & Schoffelen / hakken in struikbeplanting en & $100 \%$ & 20 & 4,0 & 4,24 \\
\hline
\end{tabular}




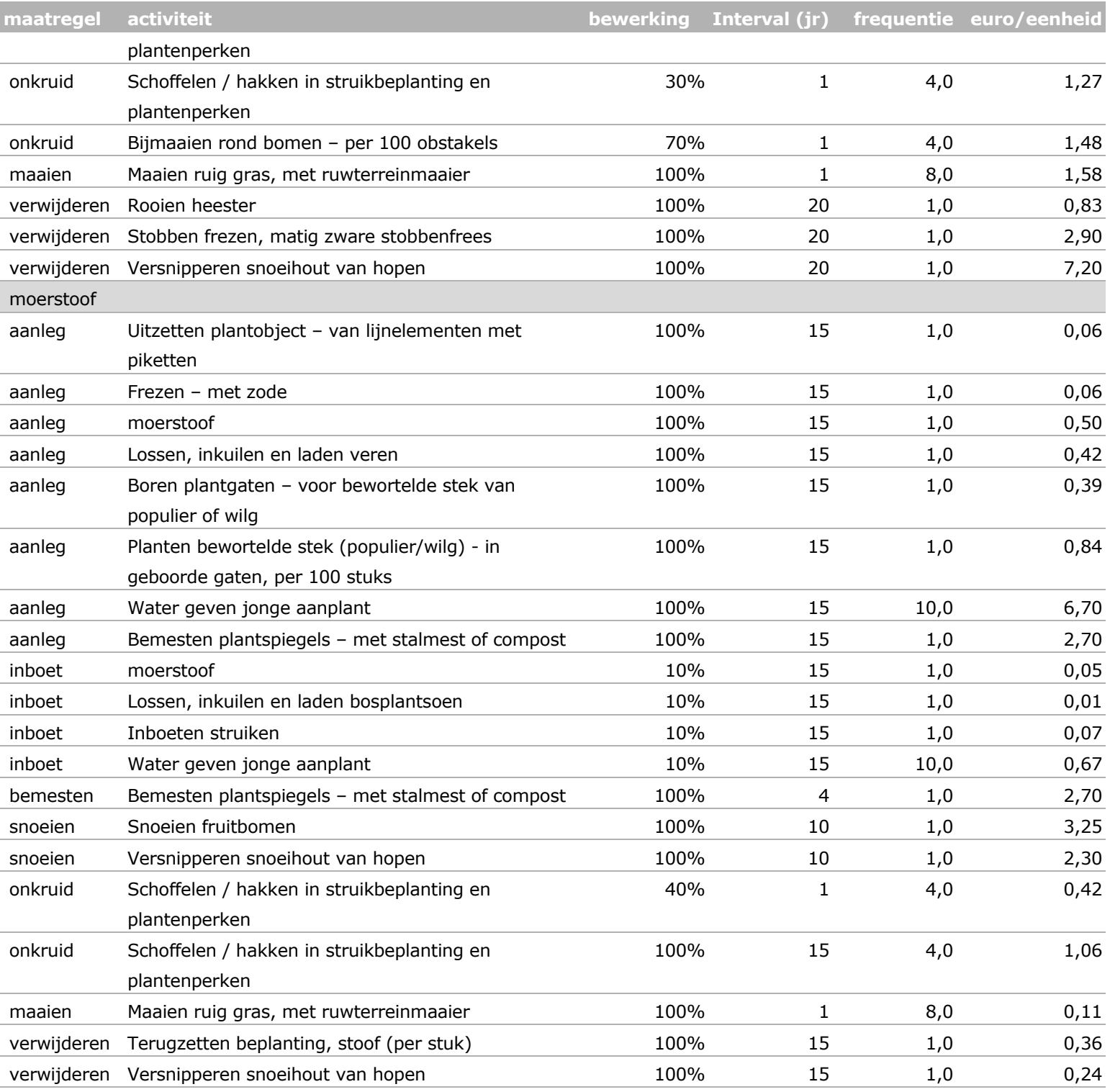




\section{Bijlage 4 Fasering aanleg zaadcollecties}

\begin{tabular}{|c|c|c|c|c|c|c|c|c|c|c|}
\hline & Jaar 1 & Jaar 2 & Jaar 3 & Jaar 4 & Jaar 5 & Jaar 6 & Jaar 7 & Jaar 8 & Jaar 9 & Jaar 10 \\
\hline \multicolumn{11}{|l|}{ Soort } \\
\hline \multicolumn{11}{|c|}{ Andromeda polifolia } \\
\hline \multicolumn{11}{|l|}{ Fraxinus excelsior } \\
\hline \multicolumn{11}{|l|}{ Ulmus glabra } \\
\hline \multicolumn{11}{|c|}{ Arctostaphylos uva-ursi } \\
\hline \multicolumn{11}{|c|}{ Daphne mezereum } \\
\hline \multicolumn{11}{|l|}{ Erica cinerea } \\
\hline \multicolumn{11}{|l|}{ Genista anglica } \\
\hline \multicolumn{11}{|c|}{ Genista germanica } \\
\hline \multicolumn{11}{|l|}{ Genista pilosa } \\
\hline \multicolumn{11}{|l|}{ Genista tinctoria } \\
\hline \multicolumn{11}{|c|}{ Juniperus communis } \\
\hline \multicolumn{11}{|l|}{ Myrica gale } \\
\hline \multicolumn{11}{|l|}{ Ulex europaeus } \\
\hline \multicolumn{11}{|c|}{ Vaccinium uliginosum } \\
\hline \multicolumn{11}{|l|}{ Acer campestre } \\
\hline \multicolumn{11}{|l|}{ Berberis vulgaris } \\
\hline \multicolumn{11}{|l|}{ Cornus mas } \\
\hline \multicolumn{11}{|l|}{ Cornus sanguinea } \\
\hline \multicolumn{11}{|c|}{ Crataegus laevigata } \\
\hline \multicolumn{11}{|c|}{ Ligustrum vulgare } \\
\hline \multicolumn{11}{|c|}{ Lonicera xylosteum } \\
\hline Malus sylvestris & & & & & & & & & & \\
\hline Rhamnus cathart & & & & & & & & & & \\
\hline Ribes rubrum & & & & & & & & & & \\
\hline Ribes uva-crispa & & & & & & & & & & \\
\hline Rosa arvensis & & & & & & & & & & \\
\hline Rosa micrantha & & & & & & & & & & \\
\hline Rosa rubiginosa & & & & & & & & & & \\
\hline Rosa sherardii & & & & & & & & & & \\
\hline Salix repens & & & & & & & & & & \\
\hline Sambucus racem & & & & & & & & & & \\
\hline Taxus baccata & & & & & & & & & & \\
\hline Tilia platyphyllos & & & & & & & & & & \\
\hline Ribes nigrum & & & & & & & & & & \\
\hline Rosa balsamica & & & & & & & & & & \\
\hline Salix aurita & & & & & & & & & & \\
\hline Salix pentandra & & & & & & & & & & \\
\hline Salix purpurea & & & & & & & & & & \\
\hline Populus nigra & & & & & & & & & & \\
\hline Rosa agrestis & & & & & & & & & & \\
\hline Rosa tomentosa & & & & & & & & & & \\
\hline Salix fragilis & & & & & & & & & & \\
\hline
\end{tabular}


CGN

Postbus 16

6700 AA Wageningen

cgn@wur.nl

www.wur.nl/cgn

Wageningen University \& Research CGN rapport 53
De missie van Wageningen University \& Research is 'To explore the potential of nature to improve the quality of life'. Binnen Wageningen University \& Research bundelen Wageningen University en gespecialiseerde onderzoeksinstituten van Stichting Wageningen Research hun krachten om bij te dragen aan de oplossing van belangrijke vragen in het domein van gezonde voeding en leefomgeving. Met ongeveer 30 vestigingen, 6.500 medewerkers ( $5.500 \mathrm{fte}$ ) en 12.500 studenten behoort Wageningen University \& Research wereldwijd tot de aansprekende kennisinstellingen binnen haar domein. De integrale benadering van de vraagstukken en de samenwerking tussen verschillende disciplines vormen het hart van de unieke Wageningen aanpak. 





CGN

Postbus 16

6700 AA Wageningen

cgn@wur.nl

www.wur.nl/cgn

Wageningen University \& Research CGN rapport 53
De missie van Wageningen University \& Research is 'To explore the potential of nature to improve the quality of life'. Binnen Wageningen University \& Research bundelen Wageningen University en gespecialiseerde onderzoeksinstituten van Stichting Wageningen Research hun krachten om bij te dragen aan de oplossing van belangrijke vragen in het domein van gezonde voeding en leefomgeving. Met ongeveer 30 vestigingen, 6.500 medewerkers ( $5.500 \mathrm{fte}$ ) en 12.500 studenten behoort Wageningen University \& Research wereldwijd tot de aansprekende kennisinstellingen binnen haar domein. De integrale benadering van de vraagstukken en de samenwerking tussen verschillende disciplines vormen het hart van de unieke Wageningen aanpak. 